André Ricardo Meinicke

\title{
Tratamento paliativo e limitação de suporte de vida no direito brasileiro
}

Monografia apresentada à Banca examinadora da Universidade de Brasília como exigência parcial para obtenção do grau de bacharelado em Direito, sob a orientação do Doutor Diaulas Costa Ribeiro.

\section{Brasília}




\section{André Ricardo Meinicke}

\section{Tratamento paliativo e limitação de suporte de vida no direito brasileiro}

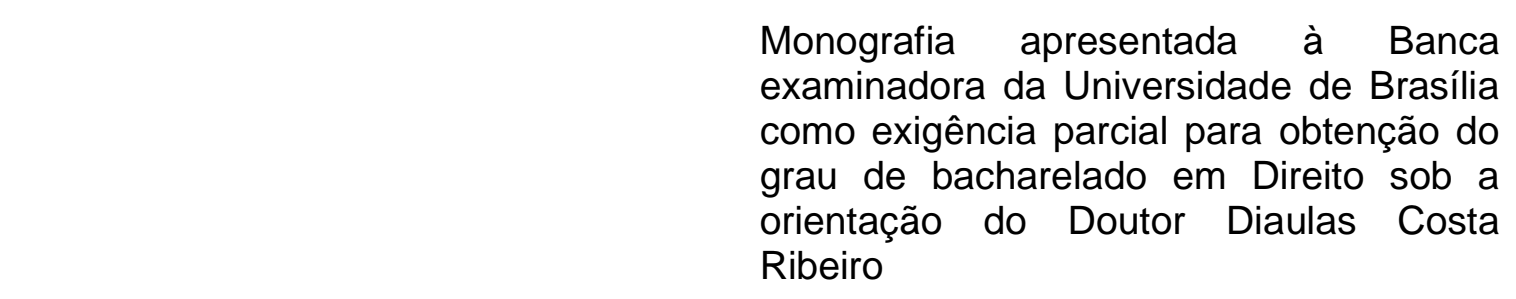

\section{Banca Examinadora:}

Presidente: Prof. Dr. Diaulas Costa Ribeiro

União Educacional do Planalto Central - UNIPLAC

Profa ${ }^{a}$. Dra ${ }^{\text {a }}$. Alejandra Leonor Pascual

Universidade de Brasília - UnB
Prof. Dr. Malthus Fonseca Galvão

Universidade de Brasília - UnB 
Dedico o presente trabalho à minha esposa Débora. 
Agradeço ao Doutor Diaulas Costa Ribeiro que me inspirou a desenvolver o tema desta monografia com seu trabalho no campo da bioética, além de me disponibilizar acesso a ampla bibliografia. Também agradeço aos meus colegas Rodrigo Nascimento de Avellar Fonseca e Paulo Montenegro pelo empréstimo de livros que foram úteis na elaboração deste trabalho. 
O mundo não é inteiramente governado pela lógica. A própria vida envolve certo tipo de violência e nós temos de escolher o caminho de menor violência.

Mahatma Gandhi 


\section{RESUMO}

O direito brasileiro adota tradicionalmente uma postura paternalista para a proteção do direito à vida, permitindo a administração de tratamentos médicos mesmo contra a vontade do paciente em caso de iminente perigo de vida. Há doutrinadores que entendem que o médico tem o dever de intervir tentando salvar a vida mesmo contra a vontade do paciente terminal. Normas mais recentes vêm mitigando essa postura tradicional ao valorizarem a autonomia da vontade dos usuários dos serviços de saúde. No entanto, há insegurança jurídica a respeito do direito dos pacientes terminais tomarem decisões de final de vida, especialmente quanto à limitação de suporte de vida. Com receio de serem punidos é comum que os médicos adotem a limitação de suporte de vida sem consultar o paciente ou seus familiares, o que revela outra forma de paternalismo. Quanto ao tratamento paliativo, já está sendo praticado no Brasil de forma livre, apesar de uns poucos entendimentos de que essa prática seria criminosa. A literatura que trata das decisões de fim de vida é confusa e carece de consenso. Não há orientação jurisprudencial sobre o assunto.

Palavras-chave: eutanásia, homicídio privilegiado, suicídio assistido, tratamento paliativo, limitação de suporte de vida. 


\section{SUMÁRIO}

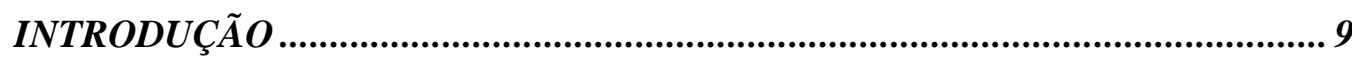

Capítulo 1.......................................................................................................... 11

Medicalização da morte............................................................................................. 11

1.1 O hospital como local de morte .............................................................................. 11

1.2 Termos relacionados ao fim da vida ................................................................. 12

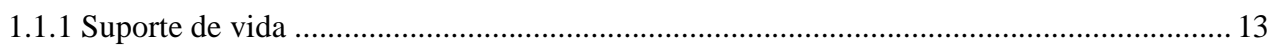

1.1.2 Limitação de suporte de vida ................................................................................... 14

1.3 A prática da limitação de suporte de vida no Brasil ................................................ 17

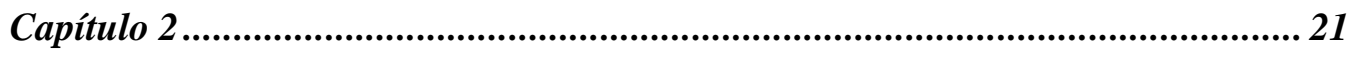

Indisponibilidade e irrenunciabilidade do direito à vida ....................................... 21

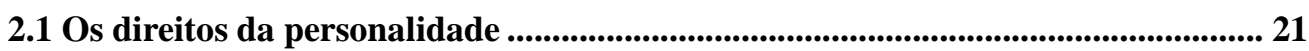

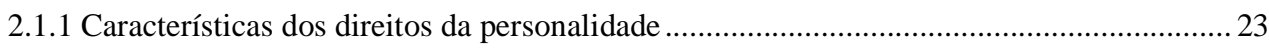

2.2 Exceções à irrenunciabilidade dos direitos da personalidade ................................... 24

2.2.1 Exceções à irrenunciabilidade do direito à integridade física .......................................... 24

2.2.2 Exceções à irrenunciabilidade do direito à vida .............................................................. 27

2.3 Indisponibilidade do direito à vida ................................................................................... 28

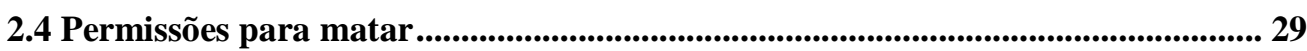

2.5 A eutanásia como homicídio privilegiado............................................................ 32

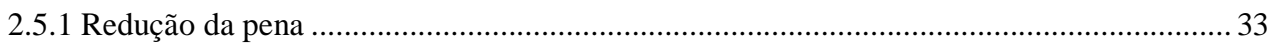

2.5.2 Responsabilidade médica ante o iminente perigo de vida ................................................ 35

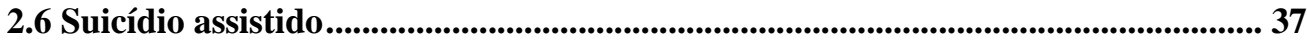

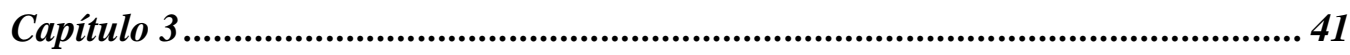

Tratamento paliativo ....................................................................................... 41

3.1 Autonomia da vontade do paciente........................................................................................ 43

3.2 Futilidade e obstinação terapêutica .................................................................................. 44

3.3 Eficácia dos tratamentos médicos ........................................................................................ 45

3.4 Duplo efeito da analgesia paliativa ...................................................................................... 48 


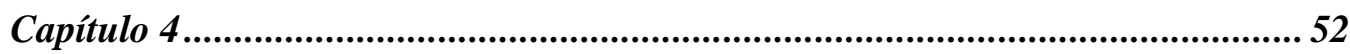

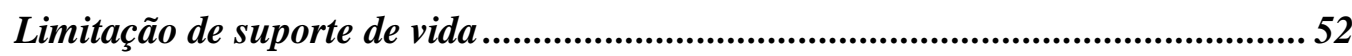

4.1 Interpretações que autorizam a limitação de suporte de vida................................. 52

4.1.1 Interpretação pela verificação da tipicidade conglobante ................................................ 53

4.1.2 A limitação de suporte de vida restrita a pacientes terminais..............................................55

4.2 A Resolução CFM n ${ }^{0} 1.805$, de 2006 ....................................................................58

4.3 Legislações locais ............................................................................................................. 59

4.3.1 Comparações entre leis estaduais e municipais................................................................. 61

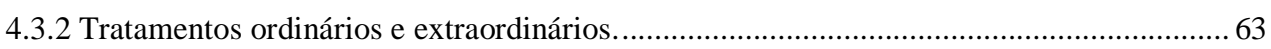

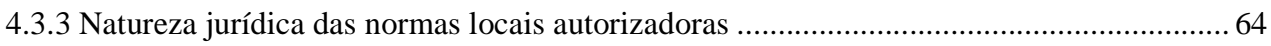

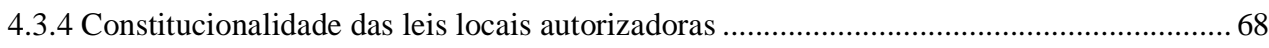

$4.4 \mathrm{O}$ costume e a jurisprudência....................................................................................... 70

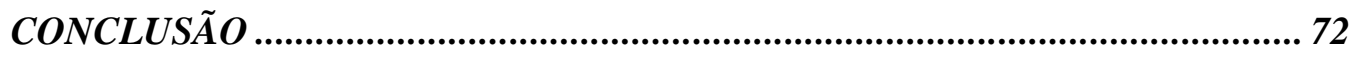

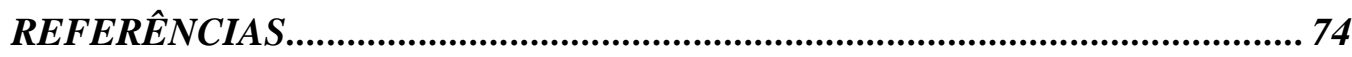




\section{INTRODUÇÃO}

O desenvolvimento tecnológico da medicina trouxe o conhecimento de novas técnicas que permitem prolongar o tempo de vida e melhorar a qualidade de vida. Nem sempre esses dois benefícios podem ser alcançados simultaneamente, havendo a possibilidade de se optar por um deles. As condições em que a pessoa se prepara para morrer também afetam a qualidade de vida. Assim, em vez de se insistir em tratamentos sem comprovação científica de eficácia na fase terminal da doença, mas que por vezes acarretam efeitos colaterais nocivos, o paciente pode preferir submeter-se a um tratamento paliativo, melhorando sua qualidade de vida dentro do possível. Também pode preferir não se submeter a tratamentos que não salvam a vida, mas apenas prolongam o período final de agonia.

Ainda há dúvida se o paciente terminal tem o direito de tomar essas decisões de final de vida, pois o direito brasileiro vinha seguindo uma tradição paternalista, em que não se permitia ao indivíduo dispor do próprio corpo e da própria vida nem mesmo em situações extremas. Essa orientação tradicional vem sendo mitigada paulatinamente por novas normas que têm ampliado a autonomia da vontade dos usuários dos serviços de saúde. Porém, o legislador federal ainda não se manifestou a respeito do assunto. Essa falta de uma orientação central abriu espaço para a criação de leis locais e de normas infralegais, cuja legitimidade e eficácia são questionadas.

No presente trabalho busca-se analisar as diversas manifestações doutrinárias a respeito das decisões de fim de vida e verificar se há certo consenso que permita uma razoável segurança jurídica a respeito do assunto.

A escolha do tema se deu pelo meu trabalho diário com procedimentos de investigação de possíveis erros médicos. Esse trabalho leva a um frequente contato com as questões de bioética. A questão das decisões de final de vida despertou minha curiosidade quando realizei análise pericial do prontuário médico em um caso em havia sido decidido não realizar novo tratamento quimioterápico pois o paciente 
sofria de câncer em fase terminal e os tratamentos anteriores não haviam tido bom resultado.

No desenvolvimento deste trabalho será utilizado o método dedutivo e a apreciação do tema será realizada a partir da técnica de pesquisa bibliográfica. Com utilização de obras e artigos especializados nos campos do direito e da medicina, além de entendimentos jurisprudenciais, todos citados na bibliografia geral.

O presente trabalho se divide em quatro capítulos. O primeiro, com o intuito de introduzir o leitor no tema trata dos problemas éticos e jurídicos surgidos devido ao recente desenvolvimento técnico da medicina, que modificou o modo pelo qual se morre. É discutido o significado do termo limitação de suporte de vida e apresentados alguns dados sobre essa prática no Brasil.

No segundo capítulo, são descritos os argumentos utilizados para a prevalência da proteção do direito à vida sobre a vontade pessoal, que revelam o tradicional caráter paternalista do direito penal brasileiro. Algumas exceções são apresentadas para demonstrar que o direito à vida não é um bem jurídico absoluto. São ainda discutidos os dois tipos penais que podem ser aplicados para punir quem age concorrendo para a morte de um paciente terminal: homicídio privilegiado e auxílio a suicídio.

No terceiro capítulo, discute-se o posicionamento de alguns autores que consideram o tratamento paliativo uma conduta criminosa. Esse posicionamento é refutado com base na autonomia da vontade do paciente, garantida em várias normas. Ainda se discute o direito à analgesia paliativa, em que pode ocorrer 0 duplo efeito: alívio da dor acompanhado de risco de morte por parada respiratória.

Por fim, é discutido o direito à limitação de suporte de vida. São apresentadas as diversas interpretações doutrinárias a respeito e os argumentos para que essa prática seja restrita aos pacientes terminais. Discute-se ainda a legitimidade e eficácia da leis locais e das normas infralegais que tratam do assunto. 


\section{Capítulo 1 \\ MEdicAlizAÇÃo dA MORTE}

O desenvolvimento tecnológico é acompanhado pela criação de novos problemas éticos e jurídicos.

\subsection{0 hospital como local de morte}

$\mathrm{Na}$ Idade Média a morte era um ato público administrado pelo próprio moribundo. Seu quarto era visitado livremente por parentes, amigos, vizinhos e mesmo crianças. O moribundo podia se despedir dos demais e receber conforto espiritual. A morte era um evento cotidiano e familiar.

A partir da segunda metade do século XIX a morte passa a ser ocultada. Manifestações de emoção devem ser reservadas, pois não são bem recebidas em público. As pessoas evitam falar sobre o assunto e quem desrespeita essa regra é afastado do convívio social. O próprio moribundo é poupado mediante a ocultação da verdade sobre seu estado. A morte tornou-se vergonhosa, um tabu. Não se morre mais em casa cercado dos entes queridos, mas no hospital. Foi retirado o direito do moribundo de tomar decisões sobre o fim da sua vida. Está quase sempre inconsciente, muitas vezes numa unidade de terapia intensiva ${ }^{1}$.

A evolução da medicina trouxe as técnicas de suporte de vida, utilizadas amplamente nas unidades de terapia intensiva. Essas técnicas possibilitam manter vivos os pacientes até que se recuperem de um quadro agudo grave. Porém essas técnicas também são utilizadas em pacientes terminais prolongando-se o tempo em que o processo natural leva à morte. Esse efeito nem sempre é desejado, mas a recusa a esses tratamentos passou a ser considerado uma forma de eutanásia, proibida pela legislação penal. Nosso Código Penal data de 1940, quando não 
existiam unidades de terapia intensiva ou técnicas de ventilação mecânica no Brasil. A legislação penal não foi modificada apesar dos progressos técnicos da medicina ${ }^{2}$.

\subsection{Termos relacionados ao fim da vida}

A literatura é bastante confusa na definição dos termos relacionados à eutanásia ${ }^{3}$. O uso contemporâneo do termo eutanásia costuma ser ambíguo, sendo comum sua complementação por adjetivos para se explicar o sentido que se pretende alcançar. Como exemplos, eutanásia ativa se refere ao homicídio direto de um paciente em sofrimento, enquanto a eutanásia passiva supõe a renúncia às técnicas médicas com o fim de permitir que o processo de morte subjacente siga seu curso natural. Eutanásia voluntária (seja ativa ou passiva) significa que se empreende a ação por ordem do paciente. Deve ser diferenciada da eutanásia não voluntária, em que o paciente não tenha feito tal exigência ou é incapaz de fazê-la, ou da eutanásia involuntária, em que a ação se realiza contra o desejo do paciente ${ }^{4}$.

O agente ativo da eutanásia não precisa ser necessariamente médico. Em geral os doutrinadores referem-se a um agente ou autor que pratica a eutanásia, sem identificá-lo como médico ${ }^{5}$. Gomes e Molina citam o exemplo extraído do filme "Menina de Ouro", em que a eutanásia é praticada pelo ex-treinador da paciente que se tornara tetraplégica em decorrência de um trauma sofrido numa luta de box ${ }^{6}$.

\footnotetext{
${ }^{1}$ ARIÈS, Philippe. História da morte no ocidente. Tradução de Priscila Viana de Siqueira. Rio de Janeiro: Ediouro, 2003, p. 25-103.

${ }^{2}$ SOARES, Márcio; TERZI, Renato G.G.; PIVA, Jefferson P. End-of-life care in Brazil. Intensive Care Medicine 2007, volume 33, p. 1014-1017.

${ }^{3}$ LEPARGNEUR, Hubert. Reflexões acerca da eutanásia. In: BARCHIFONTAINE, Christian de Paul de; PESSINI, Leo (organizadores). Bioética: alguns desafios. São Paulo: Loyola, 2001, p. 299-300.

${ }^{4}$ DRANE, James F. El cuidado del enfermo terminal. Ética clínica y recomendaciones prácticas paras instituciones de salud y servicios de cuidados domiciliarios. Washington: Organização Panamericana da Saúde, 1999, p. 160.

${ }^{5}$ MIRABETE, Julio Fabbrini. Manual de direito penal: parte especial (arts. 121 a 234 do CP). 24. ed. Revista e atualizada por Renato N. Fabbrini. São Paulo: Atlas, 2006, volume 2, p. 34.

PIERANGELI, José Henrique. Manual de direito penal brasileiro: parte especial (arts. 121 a 234). São Paulo: Editora Revista dos Tribunais, 2005, p. 61.

PRADO, Luiz Regis. Curso de direito penal brasileiro: parte especial - arts. 121 a 249. 7. ed. rev. atual. e ampl. São Paulo: Editora Revista dos Tribunais, 2008, volume 2, p. 69.

${ }^{6}$ GOMES, Luiz Flávio (coordenador); MOLINA, Antonio García-Pablos de. Direito penal: parte geral. São Paulo: Editora Revista dos Tribunais, 2007, volume 2, p. 291.
} 


\subsubsection{Suporte de vida}

Suporte de vida é o termo utilizado em medicina para designar as técnicas que visam evitar a morte de paciente com as funções vitais ausentes ou gravemente comprometidas, especialmente os sistemas respiratório e cardiovascular ${ }^{7}$.

Suporte básico de vida refere-se à seqüência de ações para salvar vidas realizadas durante os poucos minutos iniciais de atendimento a uma emergência. Essas ações são críticas em relação à sobrevivência da vítima. Algumas técnicas de suporte básico de vida podem ser aplicadas por qualquer pessoa treinada, mesmo que não seja profissional de saúde. Em casos de urgência é importante que algumas técnicas de suporte básico de vida sejam prestadas antes mesmo da vítima ser levada a um serviço médico. Nos casos de parada cardiorrespiratória a participação da população leiga tem fundamental importância, bem como a participação médica ${ }^{8}$.

Suporte avançado de vida é ato médico e consiste no emprego de técnicas especiais para evitar a morte de paciente. $O$ suporte avançado de vida tem maior complexidade e deve ser realizado somente por médicos ou por profissionais de saúde sob a supervisão direta de médicos ${ }^{9}$.

Podem ser citadas como técnicas de suporte de vida: reanimação cardiorrespiratória, métodos dialíticos, antibioticoterapia, infusão de drogas vasoativas e fluidos, transfusão sanguínea, ventilação mecânica, nutrição, sedação e analgesia ${ }^{10}$. As técnicas de suporte avançado de vida são típicas das unidades de terapia intensiva ${ }^{11}$, mas também são utilizados em outros setores dos hospitais.

\footnotetext{
7 AMERICAN ACADEMY OF ORTHOPAEDIC SURGEONS. Socorros médicos de emergência. Tradução de Lís Araújo Zin. Fortaleza: Secretaria de Saúde do Estado do Ceará, 1988, p. 61. ISSA, Luciana Jardim; REIS, Amélia Gorete. Suporte avançado de vida na criança. In: NOBRE, Fernando; SERRANO Jr., Carlos V. (editores) Tratado de cardiologia SOCESP. Barueri/SP: Manole, 2005, p. 1606.

${ }^{8}$ MARQUES, Flávio Rocha Brito; TIMERMAN, Sergio; FERREIRA, Dario Fortes; QÜILICI, Ana Paula; GONÇALEZ, Maria Margarita Castro; RAMIRES, José Antônio Franchini. Suporte básico de vida no adulto. In: NOBRE, Fernando; SERRANO Jr., Carlos V. (editores) Tratado de cardiologia SOCESP. Barueri/SP: Manole, 2005, p. 1586-1596.

${ }_{9}$ MORETTI, Miguel Antonio. Suporte avançado de vida no adulto. In: NOBRE, Fernando; SERRANO Jr., Carlos V. (editores) Tratado de cardiologia SOCESP. Barueri/SP: Manole, 2005, p. 1597.

${ }^{10}$ BITENCOURT, Almir Galvão Vieira; DANTAS, Maira Pereira; NEVES, Flávia Branco Cerqueira Serra; ALMEIDA, Alessandro de Moura; MELO, Rodrigo Morel Vieira de; ALBUQUERQUE, Ligia
} 
As técnicas de suporte de vida são úteis para reverter o quadro clínico de iminente perigo de vida. No entanto, várias dessas técnicas também são úteis para evitar que o quadro clínico se agrave a ponto do perigo de vida tornar-se iminente, ou para manter o quadro clínico estável ou controlado após ter sido afastado um iminente perigo de vida. Portanto, a administração de técnicas de suporte de vida não significa necessariamente que a condição clínica do paciente é de iminente perigo de vida.

\subsubsection{Limitação de suporte de vida}

Nesta monografia é utilizado o termo limitação de suporte de vida para designar a retirada ou a não administração dessas técnicas capazes de prolongar o tempo de vida do paciente.

Limitação de suporte de vida é um termo utilizado na literatura médica ${ }^{12}$. $\mathrm{Na}$ literatura das áreas de bioética ${ }^{13}$ e de direito ${ }^{14}$ geralmente são utilizados diversos outros termos que correspondem à limitação de suporte de vida em maior ou menor grau, como eutanásia passiva, ortotanásia, suspensão do esforço terapêutico etc. Existe uma grande confusão, não apenas na comunidade leiga, mas também por

Carvalho; GODINHO, Tiana Mascarenhas; AGARENO, Sydney; TELES, José Mário M.; FARIAS, Augusto M.C.; MESSEDER, Otavio H. Condutas de limitação terapêutica em pacientes internados em unidade de terapia intensiva. Revista Brasileira de Terapia Intensiva 2007, volume 19(2), p. 137-143. SOARES, Márcio; TERZI, Renato G.G.; PIVA, Jefferson P. End-of-life care in Brazil. Intensive Care Medicine 2007, volume 33, p. 1014-1017.

11 TERZI, Renato; ARAÚJO, Sebastião. Técnicas básicas em U.T.I. São Paulo: Manole, 1992,444 p.

12 LAGO, Patrícia M.; PIVA, Jefferson; KIPPER, Délio; GARCIA, Pedro Celiny; PRETTO, Cristiane; GIONGO, Mateus; BRANCO, Ricardo; BUENO, Fernanda; TRAIBER, Cristiane; ARAÚJO, Taisa; WORTMANN, Daniela; LIBRELATO, Graziela; SOARDI, Deise. Life support limitation at three pediatric intensive care units in southern Brazil. Jornal de Pediatria 2005, volume 81(2). p. 111-117. LAGO, Patrícia M.; DEVICTOR, Denis; PIVA, Jefferson; BERGOUNIOUX, Jean. End-of-life care in children: the Brazilian and the international perspectives. Jornal de Pediatria 2007, volume 83(2Supl.), p. S109-S116.

SOARES, Márcio; TERZI, Renato G.G.; PIVA, Jefferson P. End-of-life care in Brazil. Intensive Care Medicine 2007, volume 33, p. 1014-1017.

13 DRANE, James F. El cuidado del enfermo terminal. Ética clínica y recomendaciones prácticas paras instituciones de salud y servicios de cuidados domiciliarios. Washington: Organização Panamericana da Saúde, 1999, p. 153-168.

PESSINI, Leo. Como lidar com o paciente em fase terminal. 5. ed. rev. e atual. Aparecida: Editora Santuário, 1990, p. 36-52. 
muitos profissionais de saúde, sobre as definições desses termos ${ }^{15}$. A falta de consenso acarreta risco de má interpretação sobre a abrangência do tema em estudo. São apresentados a seguir alguns exemplos extraídos da doutrina penal brasileira, para demonstrar a falta de consenso sobre os conceitos relacionados à eutanásia.

Pierangeli chama a eutanásia passiva de ortotanásia, que corresponderia à conduta omissiva do médico que renuncia a medidas susceptíveis de conservar ou prolongar a vida. Discorre a respeito dos argumentos favoráveis e contrários à eutanásia e à ortotanásia, utilizados por outros doutrinadores e no direito comparado. No entanto, não assume um posicionamento pessoal sobre $o$ assunto ${ }^{16}$.

Prado e Mirabete consideraram haver formas de limitação de suporte de vida que não correspondem ao conceito de eutanásia. No entanto, não apresentaram qualquer alternativa à imputação penal como homicídio privilegiado para as diversas formas de limitação de suporte de vida.

Prado identifica a eutanásia como uma das hipóteses de homicídio privilegiado. Chama de eutanásia passiva a omissão de tratamento ou de qualquer meio que contribua para a prolongação da vida humana irreversivelmente comprometida, acelerando assim o desenlace mortal. A ortotanásia seria a supressão de cuidados de reanimação em pacientes em estado de coma profundo e irreversível, em estado terminal ou vegetativo ${ }^{17}$. De acordo com os conceitos adotados por esse autor, a eutanásia passiva e a ortotanásia correspondem a formas de limitação de suporte de vida, sendo a ortotanásia restrita somente à supressão de reanimação cardiorrespiratória.

Mirabete considerava puníveis a eutanásia e mesmo a ortotanásia. Identificava a eutanásia com a ação ou a omissão do sujeito que, por sua natureza

\footnotetext{
${ }^{14}$ BRITO, António José dos Santos Lopes de; RIJO, José Manuel Subtil Lopes. Estudo jurídico da eutanásia em Portugal: direito sobre a vida ou dever de viver? Coimbra: Almedina, 2000, p. 23-36.

${ }^{15}$ SOARES, Márcio; TERZI, Renato G.G.; PIVA, Jefferson P. Série temática - Terminalidade da vida e cuidados de final de vida na unidade de terapia intensiva. Revista Brasileira de Terapia Intensiva 2007, volume 19(3), p. 357-358.

${ }^{16}$ PIERANGELI, José Henrique. Manual de direito penal brasileiro: parte especial (arts. 121 a 234). São Paulo: Editora Revista dos Tribunais, 2005, p. 60-63.
} 
ou intenção, causa a morte com a finalidade de evitar a dor. Considerava ortotanásia o emprego de remédios paliativos e o acompanhamento médico sem procedimento de cura $^{18}$. De acordo com os conceitos adotados por esse autor, a eutanásia e a ortotanásia poderiam incluir atos de limitação de suporte de vida.

Outros autores, com outros conceitos relacionados à eutanásia, consideram haver possibilidade de não configurar crime algumas formas de limitação de suporte de vida ou mesmo a eutanásia.

Branco considera proibida a eutanásia. No entanto, entende que pode haver justificação para a suspensão de tratamentos extraordinários a um paciente terminal ou para a administração de droga para conter as dores atrozes de um paciente terminal, mesmo com a conseqüência previsível mas não querida de abreviar sua vida. Estas hipóteses não configuram eutanásia, no entender desse autor. Já a suspensão de tratamentos ordinários, como o auxílio externo para a respiração ou a alimentação, não seriam justificados ${ }^{19}$. Destarte, de acordo com o pensamento desse autor a eutanásia é proibida, assim como a limitação de suporte de vida pela suspensão de tratamentos ordinários. Por outro lado, seria justificada a limitação de suporte vital pela suspensão de tratamentos extraordinários.

Gomes e Molina utilizam o termo ortotanásia para designar os procedimentos de limitação de suporte de vida. Consideram haver distinção entre a eutanásia ativa e a ortotanásia. Para esses autores a ortotanásia também pode ser denominada eutanásia passiva, morte no tempo certo e limitação ou suspensão do esforço terapêutico. Assim, a limitação de suporte de vida corresponderia à forma passiva da eutanásia. Esses autores entendem que mesmo sem uma legislação específica, já existiria base no ordenamento jurídico brasileiro e no direito

17 PRADO, Luiz Regis. Curso de direito penal brasileiro: parte especial - arts. 121 a 249. 7. ed. rev. atual. e ampl. São Paulo: Editora Revista dos Tribunais, 2008, volume 2, p. 69.

${ }^{18}$ MIRABETE, Julio Fabbrini. Manual de direito penal: parte especial (arts. 121 a 234 do CP). 24. ed. Revista e atualizada por Renato N. Fabbrini. São Paulo: Atlas, 2006, volume 2, p. 34.

${ }^{19}$ BRANCO, Paulo Gustavo Gonet. Direito à vida. In: MENDES, Gilmar Ferreira; COELHO, Inocêncio Mártires; BRANCO, Paulo Gustavo Gonet. Curso de direito constitucional. 4. ed. rev. e atual. São Paulo: Saraiva, 2009, p. 399. 
internacional para se admitir a exclusão da tipicidade nos casos de eutanásia, desde que respeitadas certos procedimentos e condições ${ }^{20}$.

O termo limitação de suporte de vida é mais adequado ao propósito desta monografia, por fazer referência direta às terapias que podem prolongar o tempo de vida. Esse termo também não antecipa um juízo de valor, o que ocorre quando se rotula a morte como "boa" (eutanásia) ou "no tempo seu certo" (ortotanásia) ${ }^{21}$.

A limitação pode total ou parcial, pela não administração ou pela retirada de terapias já iniciadas. Por outro lado, o termo suspensão do esforço terapêutico sugere apenas a retirada das terapias já iniciadas.

A limitação de suporte de vida tem como possível resultado o não prolongamento artificial do tempo de vida do paciente. Essa possível alteração do tempo de vida é elemento essencial na análise da relevância criminal da omissão de um tratamento médico.

\subsection{A prática da limitação de suporte de vida no Brasil}

De acordo com reportagens publicadas pela imprensa leiga, a limitação de suporte de vida é praticada em hospitais brasileiros, conforme admitido por vários médicos entrevistados ${ }^{22}$.

A literatura médica ${ }^{23}$ revela que houve aumento da frequência da prática de limitação do suporte de vida em três unidades de terapia intensiva pediátrica na

${ }^{20}$ GOMES, Luiz Flávio (coordenador); MOLINA, Antonio García-Pablos de. Direito penal: parte geral. São Paulo: Editora Revista dos Tribunais, 2007, volume 2, p. 290-295 e p. 371.

${ }^{21}$ PESSINI, Leo. Como lidar com o paciente em fase terminal. 5. ed. rev. e atual. Aparecida: Editora Santuário, 1990, p. 36-47.

${ }^{22}$ COLLUCCI, Cláudia; LEITE, Fabiane; GOIS, Antônio. Médicos revelam que eutanásia é prática habitual em UTIs do país. Folha de São Paulo 20/02/2005. Disponível em: <http://www1.folha.uol.com.br/folha/cotidiano/ult95u105876.shtml> Data da consulta: 04/05/2009. IWASSO, Simone. Nas UTIs, 30\% dos pacientes são terminais. O Estado de São Paulo 29/07/2006. Disponível em: <http://www.estado.com.br/editorias/2006/07/29/ger-1.93.7.20060729.4.1. xml> Data da consulta: 24/04/2009.

SCHELP, Diogo. Até onde prolongar a vida: Como médicos e familiares decidem se devem ou não suspender os chamados tratamentos fúteis, que apenas mantêm vivos doentes para os quais não há esperança de cura. Veja 04/09/2002. Disponível em: 
região sul, de 6\% em 1988 para 30\% em 1998. Dados mais recentes indicam uma incidência de cerca $36 \%$ de mortes precedidas de alguma forma de limitação do suporte de vida em serviços de UTI pediátrica nas regiões sul e sudeste. No entanto, em menos de $10 \%$ dos casos a família participou do processo de decisão ${ }^{24}$.

A forma mais comum de limitação do suporte de vida nos hospitais brasileiros é a ordem de não ressuscitar (ONR). Com base nessa ordem, se o paciente sofrer naturalmente uma parada cardiorrespiratória não deve ser submetido às manobras de reanimação, sobrevindo rapidamente a morte. Mesmo nos casos em que as manobras de reanimação não são aplicadas antes da morte, os pacientes geralmente receberam outras medidas de suporte de vida como infusão de drogas vasoativas, instituição via aérea artificial e ventilação mecânica ${ }^{25}$. A limitação dessas outras formas de suporte de vida é pouco mais frequente quando a decisão de não ressuscitar é estabelecida previamente ${ }^{26}$.

Em três hospitais de Porto Alegre, de 2004 a 2005, alguma forma de limitação de suporte de vida foi praticada em $86 \%$ dos pacientes que faleceram nas unidades de terapia intensiva, mas apenas $25 \%$ das famílias partilhou dessas decisões com a equipe médica ${ }^{27}$.

<http://veja.abril.com.br/040902/p_082.html> Data da consulta: 24/04/2009.

${ }^{23}$ KIPPER, D.J.; PIVA, J.P.; GARCIA, P.C.; EINLOFT, P.R.; BRUNO, F.; LAGO, P. et al. Evolution of the medical practices and mode of death on pediatric intensive care units in Southern Brazil. Pediatric Critical Care Medicine 2005 volume 6. p. 258-263. apud LAGO, Patrícia Miranda; GARROS, Daniel; PIVA, Jefferson P. Participação da família no processo decisório de limitação de suporte de vida: paternalismo, beneficência e omissão. Revista Brasileira de Terapia Intensiva 2007, volume 19(3), p. 364-368.

${ }^{24}$ LAGO, Patrícia M.; PIVA, Jefferson; KIPPER, Délio; GARCIA, Pedro Celiny; PRETTO, Cristiane; GIONGO, Mateus; BRANCO, Ricardo; BUENO, Fernanda; TRAIBER, Cristiane; ARAÚJO, Taisa; WORTMANN, Daniela; LIBRELATO, Graziela; SOARDI, Deise. Life support limitation at three pediatric intensive care units in southern Brazil. Jornal de Pediatria 2005, volume 81(2). p. 111-117.

${ }^{25}$ OTHERO, Jairo Constante Bitencourt. Atitudes médicas nas últimas 48 horas de vida de pacientes adultos internados em três unidades de tratamento intensivo no sul do Brasil. Dissertação de mestrado. Orientador Jefferson Pedro Piva. Porto Alegre: Pontifícia Universidade Católica do Rio Grande do Sul, 2008, 100 p.

Disponível em: <http://tede.pucrs.br/tde_busca/arquivo.php?codArquivo=1444>

Data da consulta: 05/06/2009.

LAGO et al., 2005, op. cit.

${ }^{26}$ LAGO et al., 2005, op. cit.

${ }^{27}$ OTHERO, op. cit. 
Um estudo realizado no Instituto da Criança, do Hospital das Clínicas da Universidade de São Paulo, entre julho de 1997 e junho de 1998 revelou que 26,7\% dos pacientes que morreram não foram submetidos a manobras de reanimação ${ }^{28}$.

Num hospital privado de Salvador foram encontradas medidas sugestivas de limitação de suporte de vida em 59,7\% dos prontuários dos pacientes falecidos entre janeiro e agosto de 2003 na unidade de terapia intensiva ${ }^{29}$.

Em um artigo de revisão foram citados três artigos em que se verificou a incidência de limitação de suporte de vida em adultos de $11 \%$ a $36,1 \%$, em unidades de terapia intensiva no Brasil. Em outros dois estudos reportaram que 98,6\% e 100\% dos profissionais pesquisados responderam que já haviam participado em processos de decisões de final de vida ${ }^{30}$.

A literatura médica também expõe alguns subterfúgios pelos quais as decisões de não ressuscitar são ocultadas pelos médicos. Um estudo revelou forte discrepância entre os relatos obtidos dos médicos e os registros contidos nos prontuários dos pacientes. Foram analisados 47 prontuários de pacientes pediátricos que morreram sem receber manobras de reanimação, de acordo com as informações obtidas diretamente dos médicos. Em 29 desses prontuários havia anotações de que os pacientes teriam sido submetidos às manobras de reanimação. Outros 7 prontuários não continham informações a respeito das manobras de reanimação. Somente 11 daqueles prontuários (23\%) continham a informação de que não foram realizadas manobras de reanimação quando o paciente apresentou parada cardiorrespiratória. Assim, em $77 \%$ dos casos a opção por não reanimar

28 TORREÃO, Lara A.; REIS, Amélia G.A.C.; TROSTER, Eduardo J.; OSELKA, Gabriel. Cardiopulmonary resuscitation: discrepancy between the actual cardiopulmonary resuscitation and the documentation in the medical record. Jornal de Pediatria 2000, volume 76(6), p. 429-433.

${ }^{29}$ BITENCOURT, Almir Galvão Vieira; DANTAS, Maira Pereira; NEVES, Flávia Branco Cerqueira Serra; ALMEIDA, Alessandro de Moura; MELO, Rodrigo Morel Vieira de; ALBUQUERQUE, Ligia Carvalho; GODINHO, Tiana Mascarenhas; AGARENO, Sydney; TELES, José Mário M.; FARIAS, Augusto M.C.; MESSEDER, Otavio H. Condutas de limitação terapêutica em pacientes internados em unidade de terapia intensiva. Revista Brasileira de Terapia Intensiva 2007, volume 19(2), p. 137-143. SOARES, Márcio; TERZI, Renato G.G.; PIVA, Jefferson P. End-of-life care in Brazil. Intensive Care Medicine 2007, volume 33, p. 1014-1017.

30 SOARES, Márcio; TERZI, Renato G.G.; PIVA, Jefferson P. End-of-life care in Brazil. Intensive Care Medicine 2007, volume 33, p. 1014-1017. 
deixou de ser registrada na documentação médica, ou por mera omissão, ou por meio de falsa afirmação em sentido contrário incluída no prontuário ${ }^{31}$.

Outro estudo comparou opiniões de médicos de diversos países. Médicos do Brasil, da Europa meridional e da Turquia informaram que preferem que as ordens de não ressuscitar sejam orais, enquanto médicos da América do Norte, Europa central e setentrional e Austrália preferem que sejam escritas ${ }^{32}$. As motivações não foram questionadas no estudo. Mesmo assim, pode se levantar a hipótese de que a preferência pela ordem oral visa evitar a produção de documento (ordem escrita), que poderia servir de prova material num eventual processo judicial.

O paternalismo dos médicos sobre as decisões de fim de vida é evidenciado pela baixa taxa de participação das famílias no processo decisório no Brasil e na América do $\mathrm{Sul}^{33}$. O assunto é tratado como tabu pelo receio de punição ${ }^{34}$. A legislação penal brasileira foi criada também de forma paternalista proibindo a eutanásia. Outras normas foram criadas desde então a respeito da autonomia da vontade dos pacientes ${ }^{35}$. Porém, ainda há insegurança jurídica a respeito da prática de limitação de suporte de vida no Brasil.

31 TORREÃO, Lara A.; REIS, Amélia G.A.C.; TROSTER, Eduardo J.; OSELKA, Gabriel. Cardiopulmonary resuscitation: discrepancy between the actual cardiopulmonary resuscitation and the documentation in the medical record. Jornal de Pediatria 2000, volume 76(6), p. 429-433.

32 YAGUCHI, Arino; TRUOG, Robert D.; CURTIS, Randall; LUCE, John M.; LEVY, Mitchell M.; MELOT, Christian; VINCENT, Jean-Louis. International differences in end-of-life attitudes in the intensive care unit. Archives of Internal Medicine 2005, volume 165, p. 1970-1975.

${ }^{33}$ LAGO, Patrícia M.; PIVA, Jefferson; KIPPER, Délio; GARCIA, Pedro Celiny; PRETTO, Cristiane; GIONGO, Mateus; BRANCO, Ricardo; BUENO, Fernanda; TRAIBER, Cristiane; ARAÚJO, Taisa; WORTMANN, Daniela; LIBRELATO, Graziela; SOARDI, Deise. Life support limitation at three pediatric intensive care units in southern Brazil. Jornal de Pediatria 2005, volume 81(2). p. 111-117; LAGO, Patrícia Miranda; GARROS, Daniel; PIVA, Jefferson P. Terminalidade e condutas de final de vida em unidades de terapia intensiva pediátrica. Revista Brasileira de Terapia Intensiva 2007, volume 19(3), p. 359-363.

SOARES, Márcio; TERZI, Renato G.G.; PIVA, Jefferson P. End-of-life care in Brazil. Intensive Care Medicine 2007, volume 33, p. 1014-1017.

OTHERO, Jairo Constante Bitencourt. Atitudes médicas nas últimas 48 horas de vida de pacientes adultos internados em três unidades de tratamento intensivo no sul do Brasil. Dissertação de mestrado. Orientador Jefferson Pedro Piva. Porto Alegre: Pontifícia Universidade Católica do Rio Grande do Sul, 2008, 100 p.

Disponível em: <http://tede.pucrs.br/tde_busca/arquivo.php?codArquivo=1444>

Data da consulta: 05/06/2009.

${ }^{34}$ SOARES, et. al., op. cit.

35 RIBEIRO, Diaulas Costa. Autonomia: viver a própria vida e morrer a própria morte. Cadernos de Saúde Pública, Rio de Janeiro, 2006, volume 22(8), p. 1749-1754. 


\section{Capítulo 2}

\section{INDISPONIBILIDADE E IRRENUNCIABILIDADE DO DIREITO À VIDA}

As pessoas têm direito à vida. Discute-se porém que a vida não seria um direito subjetivo de cada pessoa. $\mathrm{O}$ direito à vida é tido por um bem jurídico da sociedade, e protegido pelo direito até mesmo contra a vontade do indivíduo, que não poderia renunciar ou dispor livremente desse direito.

\subsection{Os direitos da personalidade}

Pessoa é o ser ao qual se atribuem direitos e obrigações. Ao conjunto de poderes conferidos ao homem para figurar nas relações jurídicas dá-se o nome de personalidade. Personalidade não é exatamente um direito, mas um conceito básico sobre o qual se apóiam os direitos. A personalidade jurídica é a projeção da personalidade íntima, psíquica de cada um. No campo jurídico a personalidade corresponde à capacidade jurídica, à possibilidade de figurar nos pólos da relação jurídica ${ }^{36}$.

A personalidade da pessoa natural é dotada de direitos fundamentais, ou personalíssimos, que incidem sobre bens imateriais ou incorpóreos, que não possuem conteúdo econômico direto e imediato. São fundamentalmente os direitos à própria vida, à liberdade e à manifestação do pensamento. A Constituição Federal ainda enumera em seu artigo $5^{\circ}$ uma série desses direitos fundamentais ${ }^{37}$.

Os conceitos expostos anteriormente têm por base a obra de Venosa ${ }^{38}$. São citados na qualidade de exemplos, para introdução ao tema dos direitos da

\footnotetext{
${ }^{36}$ VENOSA, Sílvio de Salvo. Direito civil: parte geral. 4. ed. São Paulo: Atlas, 2004, volume 1, p. 147149.

${ }^{37}$ VENOSA, op. cit., p. 149.

${ }^{38}$ VENOSA, op. cit., p. 147-149.
} 
personalidade. Porém, cabe ressalvar que não constituem consenso entre os operadores do direito.

Os direitos da personalidade são uma construção teórica recente. A doutrina não é uniforme quanto à existência, conceituação, natureza e âmbito de incidência desses direitos ${ }^{39}$.

A princípio os direitos humanos são os mesmos direitos da personalidade. No enfoque do direito constitucional os direitos humanos são os direitos essenciais do indivíduo em relação ao direito público, como forma de proteção contra as arbitrariedades do Estado. No enfoque do direito privado os direitos da personalidade são os mesmos direitos nas relações entre particulares, como forma de proteção contra os atentados perpetrados por outras pessoas ${ }^{40}$.

O direito e a política vêm reconhecendo direitos da personalidade, havendo assim necessidade de uma construção normativa que os discipline. A proteção da pessoa humana ainda exige adequação do direito às mudanças decorrentes do progresso científico e tecnológico. Os direitos da personalidade são terreno de encontro privilegiado entre 0 direito privado, as liberdades públicas e 0 direito constitucional. Porém, é difícil encontrar na sistemática jurídica uma previsão coerente para os direitos da personalidade, dada a imaterialidade de seus aspectos essenciais ${ }^{41}$.

Busca-se encontrar nos sistemas de pensamento uma justificativa para os direitos fundamentais. Disputam várias vertentes filosófico-jurídicas na tentativa de explicar definitivamente a razão de ser desses direitos. Essas vertentes desenvolveram múltiplas concepções filosóficas, muitas vezes excludentes entre si. Para os jusnaturalistas os direitos dos homens são imperativos do direito natural, anteriores e superiores à vontade do Estado. Para os positivistas são faculdades outorgadas e reguladas pela lei. Para os idealistas os direitos humanos são idéias,

${ }^{39}$ AMARAL, Francisco. Direito civil: introdução. 7. ed. rev., atual. e aum. Rio de Janeiro: Renovar, 2008, p. 284.

${ }^{40}$ SÁ, Maria de Fátima Freire de. Direito de morrer: eutanásia, suicídio assistido. 2. ed. Belo Horizonte: Del Rey, 2005, p. 15-16.

${ }^{41}$ AMARAL, op. cit., p. 284-285. 
princípios abstratos que a realidade vai acolhendo ao longo do tempo. Para os realistas seriam o resultado direto de lutas sociais e políticas ${ }^{42}$.

A dificuldade em harmonizar as muitas concepções torna duvidosa a utilidade de se buscar uma base filosófica dos direitos fundamentais. A própria diversidade de direitos tidos como fundamentais já sugere ser impraticável tentar estabelecer um embasamento absoluto, válido para todos os direitos em todos os tempos. Além da motivação filosófica, o reconhecimento de um direito como fundamental depende de condições sociais e históricas favoráveis. Alguns entendem que o problema mais premente está na necessidade de se promover a proteção desses direitos ${ }^{43}$.

No entanto a matéria não é tratada sistematicamente na maioria dos códigos civis. Pela sua natureza especial, não se aceita que a lei possa regular de forma exauriente os direitos da personalidade ${ }^{44}$.

\subsubsection{Características dos direitos da personalidade}

As características dos direitos da personalidade também não são elencadas de forma exaustiva na lei. A doutrina descreve várias dessas características, mas seu elenco varia de acordo com o autor. Venosa descreve os direitos da personalidade como inatos, vitalícios, imprescritíveis, inalienáveis, absolutos, extrapatrimoniais, intransmissíveis, irrenunciáveis e indisponíveis ${ }^{45}$.

Algumas dessas características são declaradas expressamente na lei:

DOS DIREITOS DA PERSONALIDADE

42 BRANCO, Paulo Gustavo Gonet. Direitos fundamentais: tópicos de teoria geral. In: MENDES, Gilmar Ferreira; COELHO, Inocêncio Mártires; BRANCO, Paulo Gustavo Gonet. Curso de direito constitucional. 4. ed. rev. e atual. São Paulo: Saraiva, 2009, p. 269.

${ }^{43}$ BRANCO, op. cit., p. 269.

${ }^{44}$ VENOSA, Sílvio de Salvo. Direito civil: parte geral. 4. ed. São Paulo: Atlas, 2004, volume 1, p. 150151 ;

DONEDA, Danilo. Os direitos da personalidade do novo Código Civil (arts. 11 a 21). In: TEPEDINO, Gustavo (coordenador). A parte geral do novo Código Civil: estudos na perspectiva civilconstitucional. 3. ed. rev. Rio de Janeiro: Renovar, 2007, p. 46-47.

${ }^{45}$ VENOSA, op. cit., p. 150-151. 
Art. 11. Com exceção dos casos previstos em lei, os direitos da personalidade são intransmissíveis e irrenunciáveis, não podendo o seu exercício sofrer limitação voluntária. ${ }^{46}$

Essas características protegidas pelo artigo 11 do Código Civil já eram fartamente apontadas na doutrina ${ }^{47}$. Assim, a irrenunciabilidade aos direitos da personalidade é defendida pela lei e pela doutrina de direito civil.

$\mathrm{Na}$ doutrina penal os direitos da personalidade são geralmente considerados indisponíveis. Essa questão é discutida adiante.

\subsection{Exceções à irrenunciabilidade dos direitos da personalidade}

A irrenunciabilidade dos direitos da personalidade não é uma característica absoluta. A seguir são apresentados alguns exemplos de exceções à irrenunciabilidade dos direitos à vida e à integridade física.

\subsubsection{Exceções à irrenunciabilidade do direito à integridade física}

A integridade física constitui um bem vital. Agredir o corpo humano é um modo de agredir a vida, pois esta se realiza naquele. Assim a integridade física é um direito fundamental do indivíduo, derivado do direito à vida ${ }^{48}$.

No capítulo do Código Civil que trata dos direitos da personalidade é elencado o direito à integridade física. A irrenunciabilidade ao direito de integridade física, já estabelecida no artigo 11, é reforçada no caput do artigo 13 que proíbe o ato de disposição do próprio corpo.

DOS DIREITOS DA PERSONALIDADE

${ }^{46}$ BRASIL, Lei no 10.406, de 10/01/2002. Código Civil. Publicado no D.O.U. de 11/01/2002.

${ }^{47}$ DONEDA, Danilo. Os direitos da personalidade do novo Código Civil (arts. 11 a 21). In: TEPEDINO, Gustavo (coordenador). A parte geral do novo Código Civil: estudos na perspectiva civilconstitucional. 3. ed. rev. Rio de Janeiro: Renovar, 2007, p. 47.

${ }^{48}$ SILVA, Jóse Afonso da. Curso de direito constitucional positivo. 28. ed. rev. e atual. São Paulo: Malheiros, 2007, p. 199. 
[...]

Art. 13 Salvo por exigência médica, é defeso o ato de disposição do próprio corpo, quando importar diminuição permanente da integridade física, ou contrariar os bons costumes.

Parágrafo único. $O$ ato previsto neste artigo será admitido para fins de transplante, na forma estabelecida em lei especial. ${ }^{49}$

No entanto, o parágrafo único do mesmo artigo reduz o âmbito da irrenunciabilidade do direito de integridade física, ao permitir o ato de disposição do próprio corpo para fins de transplante. A Lei no 9.434 estabelece as condições para o transplante de órgãos com doador vivo no Brasil. Assim, a doação de um rim por exemplo, que acarreta diminuição permanente da integridade física, pode ser autorizado como ato de disposição do próprio corpo, desde que cumpridas as exigências legais.

Art. 9o É permitida à pessoa juridicamente capaz dispor gratuitamente de tecidos, órgãos e partes do próprio corpo vivo, para fins terapêuticos ou para transplantes em cônjuge ou parentes consangüíneos até o quarto grau, inclusive, na forma do $\S 4^{\circ}$ deste artigo, ou em qualquer outra pessoa, mediante autorização judicial, dispensada esta em relação à medula óssea. ${ }^{50}$

O próprio Código Civil estabelece a irrenunciabilidade do direito de integridade física como característica sujeita a restrições, não absoluta. $\mathrm{O}$ art. 11, $\mathrm{CC}$, ainda estabelece que a lei pode autorizar outras exceções à irrenunciabilidade dos direitos da personalidade.

Doneda entende que a reserva expressa no artigo 11, CC, ("Com exceção dos casos previstos em lei [...]") não abre a possibilidade de se limitar arbitrariamente a tutela dos direitos da personalidade por meio de atos legislativos ordinários. Essa reserva seria voltada para a previsão legislativa de juízos de ponderação e razoabilidade em casos de colisão de direitos ${ }^{51}$.

No entanto, outra exceção à irrenunciabilidade do direito de integridade física encontra-se na legislação ordinária. Está em vigor a Lei no 9.263 que autoriza

\footnotetext{
${ }^{49}$ BRASIL, Lei no 10.406, de 10/01/2002. Código Civil. Publicado no D.O.U. de 11/01/2002.

${ }^{50}$ BRASIL, Lei oํ 9.434, de 04/02/1997. Dispõe sobre a remoção de órgãos, tecidos e partes do corpo humano para fins de transplante e tratamento e dá outras providências. Publicada no D.O.U. de 05/02/1997.
} 
o planejamento familiar. Desde que cumpridas as exigências legais, mulheres e homens podem submeter-se a ato de disposição do próprio corpo acarretando diminuição permanente da integridade física por meio das cirurgias de laqueadura tubária e de vasectomia, respectivamente.

Art. 10. Somente é permitida a esterilização voluntária nas seguintes situações:

I - em homens e mulheres com capacidade civil plena e maiores de vinte e cinco anos de idade ou, pelo menos, com dois filhos vivos, desde que observado o prazo mínimo de sessenta dias entre a manifestação da vontade e 0 ato cirúrgico, período no qual será propiciado à pessoa interessada acesso a serviço de regulação da fecundidade, incluindo aconselhamento por equipe multidisciplinar, visando desencorajar a esterilização precoce;

$[\ldots]$

§ 4ํำ A esterilização cirúrgica como método contraceptivo somente será executada através da laqueadura tubária, vasectomia ou de outro método cientificamente aceito, sendo vedada através da histerectomia e ooforectomia.

$[\ldots]^{52}$

Assim, o parágrafo único do artigo 13 do Código Civil não encerra todo elenco de exceções à irrenuncibilidade do direito de integridade física. A legislação ordinária de fato estabelece outra exceção à irrenunciabilidade dos direitos da personalidade.

Vários outros atos que afetam a integridade física são admitidos na doutrina como justificados mediante o consentimento, ou seja, a renúncia a uma parcela da integridade física. Como exemplos: tatuagem, intervenções médicas (incluindo cirurgia estética), esportes perigosos (violentos, motorizados, radicais) ${ }^{53}$.

${ }^{51}$ DONEDA, Danilo. Os direitos da personalidade do novo Código Civil (arts. 11 a 21). In: TEPEDINO, Gustavo (coordenador). A parte geral do novo Código Civil: estudos na perspectiva civilconstitucional. 3. ed. rev. Rio de Janeiro: Renovar, 2007, p. 48.

${ }^{52}$ BRASIL, Lei no 9.263 , de 12/01/1996. Regula o § 70 do art. 226 da Constituição Federal, que trata do planejamento familiar, estabelece penalidades e dá outras providências. Publicada no D.O.U. de 15/01/1996.

${ }^{53}$ GOMES, Luiz Flávio (coordenador); MOLINA, Antonio García-Pablos de. Direito penal: parte geral. São Paulo: Editora Revista dos Tribunais, 2007, volume 2, p. 370.

MARQUES, José Frederico. Tratado de direito penal. 1. ed. atual. Campinas: Bookseller, 1997, volume 2, p. 193-195.

MIRABETE, Julio Fabbrini. Manual de direito penal: parte geral (arts. 1ㅇ a 120 do CP). 23. ed. Revista e atualizada por Renato N. Fabbrini. São Paulo: Atlas, 2006, volume 1, p. 189.

NORONHA, Edgard Magalhães. Direito penal. 12. ed. São Paulo: Saraiva, 1973, volume 1, p. 196198.

PRADO, Luiz Regis. Curso de direito penal brasileiro: parte geral - arts. $1^{\circ}$ a 120. 7. ed. rev. atual. e ampl. São Paulo: Editora Revista dos Tribunais, 2007, volume 1, p. 414. 


\subsubsection{Exceções à irrenunciabilidade do direito à vida}

O direito à vida é garantido pela Constituição Federal, que ainda estabelece sua inviolabilidade (art. 5, caput, CF).

Art. $5^{\circ}$ Todos são iguais perante a lei, sem distinção de qualquer natureza, garantindo-se aos brasileiros e aos estrangeiros residentes no País a inviolabilidade do direito à vida, à liberdade, à segurança e à propriedade, nos termos seguintes: $[\ldots]^{54}$

Várias atividades exigem a exposição a risco de vida, como certas profissões (bombeiros, policiais, pilotos, artistas circenses, etc). Algumas atividades são justificadas por serem necessárias à sociedade. Outras são expressões da liberdade de agir do indivíduo. A exposição a risco de vida pode ter motivação meramente hedonista. A pessoa pode consentir com o risco de vida (renunciando em parte ao direito à vida) para obter prazer, sem necessidade de cumprir um dever ou resultar em algum benefício para a sociedade.

O Código Civil acresce ao direito à vida a proibição de sua exposição forçada a risco, por meio de cirurgia ou outro tratamento médico.

Art. 15. Ninguém pode ser constrangido a submeter-se, com risco de vida, a tratamento médico ou a intervenção cirúrgica. ${ }^{55}$

Levando-se em conta que qualquer cirurgia apresenta maior ou menor risco de vida, a princípio sempre haverá necessidade de autorização do paciente ou de alguém por ele $^{56}$. O risco relacionado ao ato cirúrgico não precisa ser justificado pela necessidade de um tratamento de saúde, como no caso da cirurgia estética em que é suficiente 0 consentimento do paciente ${ }^{57}$. Numa cirurgia estética o paciente consente com o risco de morte, podendo ser motivado somente pelo prazer da beleza física.

${ }^{54}$ BRASIL, Constituição da República Federativa do Brasil, de 05/10/1988. Publicada no D.O.U. de 05/10/1988.

${ }^{55}$ BRASIL, Lei no 10.406, de 10/01/2002. Código Civil. Publicado no D.O.U. de 11/01/2002.

${ }^{56}$ VENOSA, Sílvio de Salvo. Direito civil: parte geral. 4. ed. São Paulo: Atlas, 2004, volume 1, p. 160.

${ }^{57}$ PRADO, Luiz Regis. Curso de direito penal brasileiro: parte geral - arts. 1ํa 120. 7. ed. rev. atual. e ampl. São Paulo: Editora Revista dos Tribunais, 2007, volume 1, p. 414. 
A doutrina reconhece o direito de se consentir com o risco de vida decorrente da prática de esportes perigosos (violentos, motorizados, radicais) ${ }^{58}$. Esses esportes podem ser praticados mesmo que por mero prazer.

\subsection{Indisponibilidade do direito à vida}

O direito à vida é considerado indisponível pela doutrina penal majoritária ${ }^{59}$. Assim, não se pode valer do consentimento da vítima para excluir a ilicitude de um homicídio, pois não cabe à vítima dispor livremente de sua própria vida.

O consentimento do ofendido, ou o prévio consentimento de quem possa validamente dispor do bem jurídico ofendido ou ameaçado, é uma das causas excludentes de ilicitude aceitas pela doutrina e pela jurisprudência. O dispositivo que elencava essa causa justificadora foi suprimido do projeto do Código Penal por ter sido considerado supérfluo, opinião também sustentada por Hungria ${ }^{60}$, mas contestada por outros autores ${ }^{61}$.

A falta do dispositivo correspondente no Código Penal acarreta algumas dificuldades para os doutrinadores explicarem a validade dessa causa justificadora nos casos em que a ausência de consentimento não é elemento integrante do tipo

${ }^{58}$ GOMES, Luiz Flávio (coordenador); MOLINA, Antonio García-Pablos de. Direito penal: parte geral. São Paulo: Editora Revista dos Tribunais, 2007, volume 2, p. 370.

MARQUES, José Frederico. Tratado de direito penal. 1. ed. atual. Campinas: Bookseller, 1997, volume 2, p. 193-195.

MIRABETE, Julio Fabbrini. Manual de direito penal: parte geral (arts. 1ํ a 120 do CP). 23. ed. Revista e atualizada por Renato N. Fabbrini. São Paulo: Atlas, 2006, volume 1, p. 189.

NORONHA, Edgard Magalhães. Direito penal. 12. ed. São Paulo: Saraiva, 1973, volume 1, p. 196198.

${ }^{59}$ CAPEZ, Fernando. Curso de direito penal: parte geral. 4. ed. rev e atual. São Paulo: Saraiva, 2002, volume 1, p. 262.

COSTA Junior, Paulo José. Comentários ao código penal. 4. ed. reform. e atual. São Paulo: Saraiva, 1996, p. 112-113.

GRECO, Rogério. Curso de direito penal: parte geral. 7. ed. Niterói: Impetus, 2006, volume 1, p. 404. MIRABETE, Julio Fabbrini. Manual de direito penal: parte geral (arts. 1ํ a 120 do CP). 23. ed. Revista e atualizada por Renato N. Fabbrini. São Paulo: Atlas, 2006, volume 1, p. 189.

${ }^{60}$ HUNGRIA, Nelson. Comentários ao código penal. 4. ed. Rio de Janeiro: Forense, 1958, volume 1, tomo 2, p. 268-269.

${ }^{61}$ MARQUES, José Frederico. Tratado de direito penal. 1. ed. atual. Campinas: Bookseller, 1997, volume 2, p. 131.

NORONHA, Edgard Magalhães. Direito penal. 12. ed. São Paulo: Saraiva, 1973, volume 1, p. 196. 
penal. Alguns doutrinadores consideram que se trata de uma causa supralegal de exclusão de ilicitude ${ }^{62}$.

Marques diverge do entendimento majoritário de que o direito à vida seria indisponível.

A disponibilidade ou indisponibilidade do bem jurídico é problema que se resolve em face dos mandamentos, princípios e regras da ordem jurídica total, inclusive o direito costumeiro.

$[\ldots]$

No delimitar o âmbito do consenso válido e relevante, esclarecem os autores que não se consideram indisponíveis o direito à vida, o direito à liberdade, o direito à honra. [...]. ${ }^{63}$

Porém, seria temerário defender a exclusão da ilicitude da limitação de suporte de vida com base apenas no consentimento do paciente como causa excludente de ilicitude. O reconhecimento do consentimento do ofendido como causa justificante tem por base a doutrina e a jurisprudência, assim como a questão da indisponibilidade do direito à vida. Assim, não seria razoável esperar que prospere uma interpretação contrária ao posicionamento majoritário em tais fontes do direito.

\subsection{Permissões para matar}

Matar outro ser humano, por ação ou omissão, a princípio configura crime no Brasil. No entanto, o direito à vida não é um bem jurídico absoluto. O direito protege a vida humana, mas não em todas as circunstâncias. De acordo com o Código Penal, não haverá crime se incidir uma das cláusulas de exclusão de ilicitude.

${ }^{62}$ GOMES, Luiz Flávio (coordenador); MOLINA, Antonio García-Pablos de. Direito penal: parte geral. São Paulo: Editora Revista dos Tribunais, 2007, volume 2, p. 370.

GRECO, Rogério. Curso de direito penal: parte geral. 7. ed. Niterói: Impetus, 2006, volume 1, p. 403. MIRABETE, Julio Fabbrini. Manual de direito penal: parte geral (arts. $1^{\circ}$ a 120 do CP). 23. ed. Revista e atualizada por Renato N. Fabbrini. São Paulo: Atlas, 2006, volume 1, p. 188.

${ }^{63}$ MARQUES, José Frederico. Tratado de direito penal. 1. ed. atual. Campinas: Bookseller, 1997, volume 2, p. 191-192. 
Assim, matar outro ser humano pode se justificar por legítima defesa ${ }^{64}$ ou pelo estado de necessidade ${ }^{65}$.

A exclusão de ilicitude pode também se manifestar pelo estrito cumprimento do dever legal de matar outrem. $\mathrm{O}$ ordenamento jurídico brasileiro admite o dever legal de matar outrem. Ainda que na forma de exceção, a Constituição Federal admite a pena de morte.

Art. $5^{\circ}$ Todos são iguais perante a lei, sem distinção de qualquer natureza, garantindo-se aos brasileiros e aos estrangeiros residentes no País a inviolabilidade do direito à vida, à liberdade, à segurança e à propriedade, nos termos seguintes:

$[\ldots]$

XLVII - não haverá penas:

a) de morte, salvo em caso de guerra declarada, nos termos do artigo 84, XIX;

$[\ldots]$

Art. 84. Compete privativamente ao Presidente da República:

$[\ldots]$

XIX - declarar guerra, no caso de agressão estrangeira, autorizado pelo Congresso Nacional ou referendado por ele, quando ocorrida no intervalo das sessões legislativas, e, nas mesmas condições, decretar, total ou parcialmente, a mobilização nacional; $[\ldots]^{66}$

O Código Penal Militar estabelece em seu Livro II, dos crimes militares em tempo de guerra, diversos tipos penais que podem ser punidos com a morte (art. 355 e seguintes, Decreto-Lei no 1001). No Brasil a pena de morte deve ser executada por meio de fuzilamento (art. 56, Decreto-Lei no 1001). Assim, a execução de pena de morte pelo pelotão de fuzilamento em época de guerra constitui estrito cumprimento de dever legal ${ }^{67}$.

A morte do inimigo produzida pelo soldado no campo de batalha em tempo de guerra também constitui estrito cumprimento de dever legal ${ }^{68}$. O cumprimento do dever militar é exigido pelo Código Penal Militar, que tipifica o descumprimento do dever militar e a cobardia.

\footnotetext{
${ }^{64} \mathrm{NUCCl}$, Guilherme de Souza. Manual de direito penal: parte geral: parte especial. São Paulo: Editora Revista dos Tribunais, 2006, p. 231.

${ }^{65} \mathrm{NUCCl}$ op. cit., p. 217.

${ }^{66}$ BRASIL, Constituição da República Federativa do Brasil, de 05/10/1988. Publicada no D.O.U. de 05/10/1988.

${ }^{67} \mathrm{NUCCl}$, op. cit., p. 237.
} 
Penas principais

Art. 55. As penas principais são:

a) morte;

$[\ldots]$

Pena de morte

Art. 56. A pena de morte é executada por fuzilamento.

[...]

Cobardia

Art. 363. Subtrair-se ou tentar subtrair-se o militar, por temor, em presença do inimigo, ao cumprimento do dever militar:

Pena - reclusão, de dois a oito anos.

$[\ldots]$

Descumprimento do dever militar

Art. 374. Deixar, em presença do inimigo, de conduzir-se de acordo com o dever militar:

Pena - reclusão, até cinco anos, se o fato não constitui crime mais grave. ${ }^{69}$

\title{
Por fim, a jurisprudência já afirmou que um homicídio não pode ser
} justificado com base em um suposto exercício regular de direito.

\begin{abstract}
Émenta oficial: Júri. Contradição de quesito. Nulidade de julgamento. É nulo o julgamento por contradição, se o Conselho de Sentença afirma ser regular o exercício de um direito e, em outro quesito, declara que o acusado excedeu culposamente o exercício daquele.

A lei não confere a quem quer que seja o direito de matar, e anula-se o julgamento absolutório que responde afirmativamente a tal tese porque a descriminante do art. 23, III, segunda parte, do CP não tem qualquer aplicabilidade a homicídio. ${ }^{70}$
\end{abstract}

Ementa Oficial: A excludente do exercício regular de direito, prevista no art. 23, III, do CP, submetida à votação dos jurados, é inteiramente inaplicável ao crime de homicídio. Inexiste no Direito Penal, ou em qualquer outro ramo da ciência jurídica, uma prerrogativa cujo exercício importe na faculdade de matar.

Ementa da Redação: Direito subjetivo de matar somente se reconhece a quem pratica homicídio em legítima defesa, em estado de necessidade ou, ainda, ao militar que, em guerra externa ou intestina, mata o inimigo no estrito cumprimento do dever legal, razão pela qual é nulo o julgamento do Júri que reconhece tal descriminante. ${ }^{71}$

$68 \mathrm{NUCCl}$, Guilherme de Souza. Manual de direito penal: parte geral: parte especial. São Paulo: Editora Revista dos Tribunais, 2006, p. 237-238.

69 BRASIL, Decreto-Lei no 1001, Código Penal Militar, de 21/10/1969. Publicado no D.O.U. de 21/10/1969.

70 ESTADO DE MINAS GERAIS, 2aㅡ Câmara Criminal do Tribunal de Justiça de Minas Gerais, Apelação 20.217, relator Desembargador Aníbal Pacheco, 01/10/1987, Revista dos Tribunais, volume 628, p. 352.

71 ESTADO DE MINAS GERAIS, 2a Câmara Criminal do Tribunal de Justiça de Minas Gerais, Apelação 39.268-8, relator Desembargador Guido de Andrade, 01/06/1995, DJ 25/06/1996, Revista dos Tribunais, volume 736, p. 676. 
Na doutrina há argumentos de que o aborto consentido no caso de gravidez resultante de estupro constitui para o médico exercício regular de direito ${ }^{72}$. Apesar de não tratar-se de homicídio, é uma hipótese em que a lei autoriza a lesão ao bem jurídico constituído pelo direito à vida. Assim, é admissível haver exercício regular do direito afetando o direito à vida.

\title{
2.5 A eutanásia como homicídio privilegiado
}

Citamos um exemplo de conceito de eutanásia, com a ressalva de que há muita variação e confusão sobre o tema:

\begin{abstract}
Segundo um conceito generalizado, o homicídio eutanásico deve ser entendido como aquêle que é praticado para abreviar piedosamente o irremediável sofrimento da vítima, e a pedido ou com o assentimento desta. $^{73}$
\end{abstract}

A princípio a eutanásia é reconhecida como crime no direito brasileiro. Apesar do termo eutanásia não constar do Código Penal, sua prática é considerada correspondente ao tipo penal do homicídio privilegiado (art. 121, $1^{\circ} \stackrel{\circ}{\mathrm{CP}}$ ), quando impelida por motivo de relevante valor moral.

Homicídio simples

Art. 121. Matar alguém:

Pena - reclusão, de seis a vinte anos

Caso de diminuição de pena

$\S 1^{\circ}$ Se o agente comete o crime impelido por motivo de relevante valor social ou moral, ou sob o domínio de violenta emoção, logo em seguida a injusta provocação da vítima, o juiz pode reduzir a pena de um sexto a um terço. ${ }^{74}$

\footnotetext{
${ }^{72}$ MARQUES, José Frederico. Tratado de direito penal. 1. ed. atual. Campinas: Bookseller, 1997, volume 2, p. 178-179.

PRADO, Luiz Regis. Curso de direito penal brasileiro: parte especial - arts. 121 a 249. 7. ed. rev. atual. e ampl. São Paulo: Editora Revista dos Tribunais, 2008, volume 2, p. 116.

${ }^{73}$ HUNGRIA, Nelson. Comentários ao código penal. 4. ed. Rio de Janeiro: Forense, 1958, volume 5, p. 127.

${ }^{74}$ BRASIL, Decreto-Lei no 2.848, de 07/12/1940. Código Penal. Publicado no D.O.U. de 31/12/1940 e retificado no D.O.U. de 03/01/1941.
} 
O próprio legislador reconheceu a correlação entre o homicídio privilegiado e a eutanásia, na Exposição de Motivos do Código Penal:

[...] Por "motivo de relevante valor social ou moral", o projeto entende significar o motivo que, em si mesmo, é aprovado pela moral prática, como por exemplo a compaixão ante o irremediável sofrimento da vítima (caso do homicídio eutanásico), a indignação contra um traidor da pátria etc. ${ }^{75}$

A doutrina majoritária ${ }^{76}$, assim como alguns julgados de Tribunais estaduais $^{77}$, também identificam a eutanásia como homicídio privilegiado, impelido por relevante valor moral.

Capez considera que o crime pode ser praticado mediante um comportamento comissivo (eutanásia ativa) ou omissivo (forma passiva). Apesar de discutir brevemente uma tese de atipicidade no caso da eutanásia omissiva, Capez afirma que é orientação pacífica na doutrina e jurisprudência brasileiras que em ambos casos ocorre homicídio privilegiado ${ }^{78}$.

\subsubsection{Redução da pena}

Quando se reconhece o relevante valor moral na prática da eutanásia, impõe-se a redução obrigatória da pena ${ }^{79}$. Por tratar-se de um homicídio privilegiado, a pena deve ser reduzida de um sexto a um terço, em relação à que seria aplicada no caso de homicídio simples.

75 BRASIL, Exposição de Motivos do Decreto-Lei no 2.848, de 7 de Dezembro de 1940. In: MIRABETE, Julio Fabbrini. Código Penal interpretado. 5. ed. Atualizada por Renato N. Fabbrini. São Paulo: Atlas, 2005, p. 63.

76 MARQUES, José Frederico. Tratado de direito penal. 1. ed. atual. Campinas: Bookseller, 1997, volume 2, p. 191-192.

77 FRANCO, Alberto Silva; STOCO, Rui (coordenadores). Código Penal e sua interpretação jurisprudencial: parte especial. 7. ed. rev., atual. e ampl. São Paulo: Editora Revista dos Tribunais, 2001, volume 2, p. 2127.

GOMES, Luiz Flávio (coordenador); MOLINA, Antonio García-Pablos de. Direito penal: parte geral. São Paulo: Editora Revista dos Tribunais, 2007, volume 2, p. 292.

MIRABETE, op. cit.

${ }^{78}$ CAPEZ, Fernando. Curso de direito penal: parte especial. São Paulo: Saraiva, 2004, volume 2, p. 34.

${ }^{79}$ GRECO, Rogério. Curso de direito penal: parte especial. 3. ed. Niterói: Impetus, 2007, volume 2, p. 157. 
Bitencourt destaca que os motivos de "relevante valor social ou moral" também estão relacionados no art. 65, III, a, CP, como circunstâncias atenuantes. Afirma porém que para se evitar o bis in idem não se deve admitir como atenuante uma circunstância que já foi reconhecida como privilegiadora no caso concreto. Portanto, se a compaixão ou a piedade ante o irremediável sofrimento da vítima foi considerada circunstância de relevante valor moral para caracterizar o homicídio como privilegiado, essa mesma circunstância não deve servir de fundamento para uma segunda atenuação da pena ${ }^{80}$.

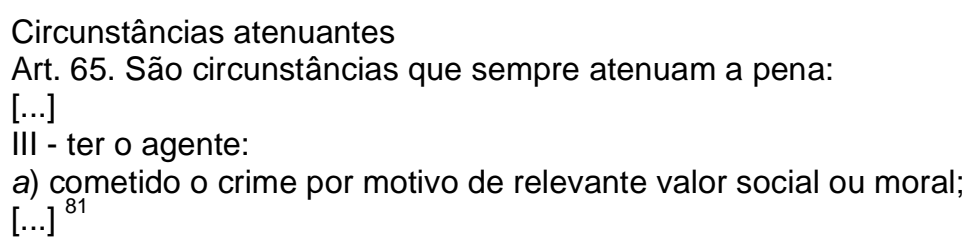

No entanto, Gomes e Molina citam outra possibilidade de atenuação da pena no caso de eutanásia, "segundo a clássica jurisprudência brasileira". O Código Penal determina ao juiz considerar sempre o comportamento da vítima na fixação da pena (art. 59, caput, CP). Assim, o consentimento da vítima em relação a sua própria morte seria uma segunda circunstância a permitir a redução da pena no caso da eutanásia, diferente da circunstância de relevante valor moral considerada como privilegiadora (afastado nesse caso o bis in idem) ${ }^{82}$.

Fixação da pena

Art. 59. O juiz, atendendo à culpabilidade, aos antecedentes, à conduta social, à personalidade do agente, aos motivos, às circunstâncias e conseqüências do crime, bem como ao comportamento da vítima, estabelecerá, conforme seja necessário e suficiente para reprovação e prevenção do crime:

$[\ldots]^{83}$

Complementando esse raciocínio quanto à relevância do consentimento expresso da vítima para redução da pena, podemos citar ainda o art. 66, CP:

${ }^{80}$ BITENCOURT, Cezar Roberto. Tratado de direito penal: parte especial. 8. ed. rev. e atual. São Paulo: Saraiva, 2008, volume 2, p. 48.

${ }^{81}$ BRASIL, Decreto-Lei no 2.848, de 07/12/1940. Código Penal. Publicado no D.O.U. de 31/12/1940 e retificado no D.O.U. de 03/01/1941.

${ }^{82}$ GOMES, Luiz Flávio (coordenador); MOLINA, Antonio García-Pablos de. Direito penal: parte geral. São Paulo: Editora Revista dos Tribunais, 2007, volume 2, p. 370-371. 
Art. 66. A pena poderá ser ainda atenuada em razão de circunstância relevante, anterior ou posterior ao crime, embora não prevista expressamente em lei.

O consentimento da vítima não constitui elemento do tipo penal previsto no

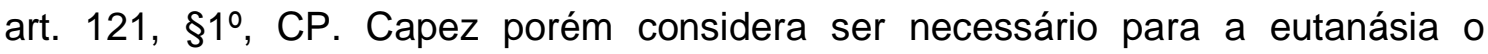
consentimento, mas admite que possa ser expresso ou presumido ${ }^{84}$.

$\mathrm{Na}$ eutanásia o consentimento expresso da vítima não constitui elemento obrigatório para que a conduta seja enquadrada como homicídio privilegiado. Dessa forma, o consentimento expresso é uma circunstância relevante, mas independente do tipo penal. Destarte, além da redução da pena própria do homicídio privilegiado, o juiz ainda pode considerar o consentimento expresso da vítima como circunstância relevante para conceder mais uma redução ao fixar a pena. Já o consentimento presumido não decorre do comportamento da vítima, o que afasta sua relevância nesse quesito.

\subsubsection{Responsabilidade médica ante o iminente perigo de vida}

A princípio o paciente tem direito de decidir aceitar ou recusar tratamentos médicos (art. 15, CC). Em contraposição, o Código Penal autoriza o constrangimento de alguém que esteja em iminente perigo de vida para ser submetido a intervenção médica.

Código Penal

Art. 146 - Constranger alguém, mediante violência ou grave ameaça, ou depois de lhe haver reduzido, por qualquer outro meio, a capacidade de resistência, a não fazer o que a lei permite, ou a fazer o que ela não manda: [...]

$\S 3^{\circ}$ - Não se compreendem na disposição deste artigo:

I - a intervenção médica ou cirúrgica, sem o consentimento do paciente ou de seu representante legal, se justificada por iminente perigo de vida; ${ }^{85}$

${ }^{83}$ BRASIL, Decreto-Lei no 2.848, de 07/12/1940. Código Penal. Publicado no D.O.U. de 31/12/1940 e retificado no D.O.U. de 03/01/1941.

${ }^{84}$ CAPEZ, Fernando. Curso de direito penal: parte especial. São Paulo: Saraiva, 2004, volume 2, p. 34.

${ }^{85}$ BRASIL, Decreto-Lei no 2.848, de 07/12/1940. Código Penal. Publicado no D.O.U. de 31/12/1940 e retificado no D.O.U. de 03/01/1941. 
O Código Penal autoriza a atuação do médico quando há um conflito extremo entre dois bens tutelados pelo direito penal, a liberdade pessoal e a vida. Em situação de iminente perigo a lei penal permite que se busque preservar a vida mediante o sacrifício da liberdade pessoal. Cabe averiguar se essa permissão da lei consiste, para o médico, numa faculdade de agir ou num dever de agir. Capez considera que o médico tem o dever de agir quando há iminente perigo de vida para o paciente:

Em face do perigo de vida, bem maior, o médico deverá optar pela intervenção médica ou cirúrgica sem o consentimento do ofendido, sacrificando, assim o bem menor (liberdade de não querer a intervenção) ${ }^{86}$.

Assim, Capez considera configurar homicídio privilegiado a morte natural do paciente sem que o médico tente interromper a cadeia de causalidade da morte. Para esse autor, a responsabilidade do médico seria decorrente de omissão imprópria, por quebra de dever legal (art. 13, §ํa, ${ }^{\circ}$ CP) ${ }^{87}$.

No entanto, ao discorrer sobre o nexo de causalidade por omissão imprópria, Capez não identifica um dispositivo específico na lei que determine o dever do médico. Considera que o médico tem o dever de garantidor em relação aos pacientes, ou seja, pela natureza de seu trabalho assume o dever de impedir o resultado (art. 13, $\left.2^{\circ}, b, \mathrm{CP}\right)^{88}$.

Relação de causalidade

Art. 13. O resultado, de que depende a existência do crime, somente é imputável a quem lhe deu causa. Considera-se causa a ação ou omissão sem a qual o resultado não teria ocorrido.

$[\ldots]$

Relevância da omissão

$\S 2^{\circ}$ - A omissão é penalmente relevante quando o omitente devia e podia agir para evitar o resultado. O dever de agir incumbe a quem:

a) tenha por lei obrigação de cuidado, proteção ou vigilância

b) de outra forma, assumiu a responsabilidade de impedir o resultado; ${ }^{89}$

${ }^{86}$ CAPEZ, Fernando. Curso de direito penal: parte especial. São Paulo: Saraiva, 2004, volume 2, p. 296.

${ }^{87}$ CAPEZ, Fernando. Curso de direito penal: parte especial. São Paulo: Saraiva, 2004, volume 2, p. 34.

${ }^{88}$ CAPEZ, Fernando. Curso de direito penal: parte geral. 4. ed. rev. e atual. São Paulo: Saraiva, 2002, volume 1, p. 146.

${ }^{89}$ BRASIL, Decreto-Lei no 2.848, de 07/12/1940. Código Penal. Publicado no D.O.U. de 31/12/1940 e retificado no D.O.U. de 03/01/1941. 
Prado também entende que a responsabilidade do médico em relação aos pacientes decorre do exercício profissional, e não de ordem específica da lei. Tratase de um dever fundamentado por aceitação voluntária, contratual ou negocial. Portanto, a responsabilidade médica seria relacionada à alínea $b$, do $\S 2^{\circ}$, art. $13, \mathrm{CP}$ ${ }^{90}$. No entanto, este autor descreve a atuação do médico ante o iminente perigo de vida do paciente como uma faculdade de agir:

Fundamenta-se o estado de necessidade porque a conduta do médico visa afastar de perigo atual ou iminente bem jurídico alheio (vida do paciente), cujo sacrifício, nas circunstâncias, não era razoável exigir-se. O mal causado (violação da liberdade pessoal) é menor do que aquele que se pretende evitar (morte). Há conflito entre bens de valor diferencial, com sacrifício do bem de menor valor. O ordenamento jurídico faculta a lesão do bem jurídico de menor valor como único meio de salvar o de maior valor. ${ }^{91}$

O entendimento de que o médico deve agir ante o iminente perigo de vida do paciente mesmo sem o seu consentimento depende de interpretação da lei penal. Vários doutrinadores já citados anteriormente seguem esse entendimento e consideram punível como homicídio privilegiado a omissão do médico nesse caso. Porém, não há unanimidade nesse entendimento, pois há quem descreva a conduta do médico nesse caso como uma faculdade de agir e quem entenda que o médico deve se abster de agir caso o paciente recuse o tratamento (essa segunda hipótese é discutida adiante).

\subsection{Suicídio assistido}

O suicídio e a tentativa de suicídio não são puníveis. $\mathrm{O}$ atentado contra a própria vida não é tipificado na legislação penal brasileira. Assim, há quem afirme que o suicídio não é ilícito penal ${ }^{92}$.

\footnotetext{
${ }^{90}$ PRADO, Luiz Regis. Curso de direito penal brasileiro: parte geral - arts. 1ํ a 120. 7. ed. rev. atual. e ampl. São Paulo: Editora Revista dos Tribunais, 2007, volume 1, p. 325.

${ }_{91}$ PRADO, Luiz Regis. Curso de direito penal brasileiro: parte especial - arts. 121 a 249. 7. ed. rev. atual. e ampl. São Paulo: Editora Revista dos Tribunais, 2008, volume 2, p. 255.

${ }_{92}$ DELMANTO, Celso; DELMANTO, Roberto; DELMANTO Junior, Roberto; DELMANTO, Fabio M. de Almeida. Código penal comentado. 7. ed. rev. atual. e ampl. Rio de Janeiro: Renovar, 2007, volume 1, p. 369.
} 
Porém a doutrina majoritária considera que, apesar de não punível, o suicídio é ilícito, fundamentando esse entendimento na indisponibilidade do direito à vida ${ }^{93}$. O suicídio também é tido como ilícito pelo argumento de que não constitui constrangimento ilegal a coação exercida para impedi-lo (art. 146, §3º, II, CP) ${ }^{94}$.

Induzimento, instigação e auxílio a suicídio são condutas tipificadas no Código Penal brasileiro (art. 122, caput, CP).

Induzimento, instigação ou auxílio a suicídio

Art. 122. Induzir ou instigar alguém a suicidar-se ou prestar-Ihe auxílio para que o faça:

Pena - reclusão, de 2 (dois) a 6 (seis) anos, se o suicídio se consuma; ou reclusão, de 1 (um) a 3 (três) anos, se da tentativa de suicídio resulta lesão corporal de natureza grave.

Parágrafo único. A pena é duplicada:

Aumento de pena

I - se o crime é praticado por motivo egoístico;

II - se a vítima é menor ou tem diminuída, por qualquer causa, a capacidade de resistência. ${ }^{95}$

O suicídio assistido consiste no auxílio para a morte de uma alguém que pratica pessoalmente o ato que conduz à sua morte, ao seu suicídio. No suicídio assistido a criação do risco é gerada pelo próprio paciente. Nesse caso o terceiro apenas auxilia, mas não pratica o ato criador do risco ${ }^{96}$.

O suicídio assistido em caso de paciente que padece de doença em fase terminal pode ser enquadrado como crime qualificado, resultando na duplicação da pena. Qualquer causa de diminuição da resistência da vítima pode ser considerada para qualificar o crime (art. 122, §U, II, CP), incluindo-se as enfermidades ${ }^{97}$. É

${ }^{93}$ BITENCOURT, Cezar Roberto. Tratado de direito penal: parte especial. 8. ed. rev. e atual. São Paulo: Saraiva, 2008, volume 2, p. 98-99.

MIRABETE, Julio Fabbrini. Manual de direito penal: parte especial (arts. 121 a 234 do CP). 24. ed. Revista e atualizada por Renato N. Fabbrini. São Paulo: Atlas, 2006, volume 2, p. 50.

NORONHA, Edgard Magalhães. Direito penal. 12. ed. São Paulo: Saraiva, 1976, volume 2, p. 41.

${ }^{94}$ HUNGRIA, Nelson. Comentários ao código penal. 4. ed. Rio de Janeiro: Forense, 1958, volume 5, p. 228.

PRADO, Luiz Regis. Curso de direito penal brasileiro: parte especial - arts. 121 a 249. 7. ed. rev. atual. e ampl. São Paulo: Editora Revista dos Tribunais, 2008, volume 2, p. 83.

${ }_{95}$ BRASIL, Decreto-Lei no 2.848, de 07/12/1940. Código Penal. Publicado no D.O.U. de 31/12/1940 e retificado no D.O.U. de 03/01/1941.

${ }_{96}$ GOMES, Luiz Flávio (coordenador); MOLINA, Antonio García-Pablos de. Direito penal: parte geral. São Paulo: Editora Revista dos Tribunais, 2007, volume 2, p. 291.

${ }_{97}$ BITENCOURT, op. cit., p. 114.

CAPEZ, Fernando. Curso de direito penal: parte especial. São Paulo: Saraiva, 2003, volume 2, p. 95. 
natural que uma enfermidade em fase terminal tenha ainda maior poder de reduzir a resistência de seu portador.

A motivação nobre (como a compaixão ou a piedade ante o irremediável sofrimento da vítima) para o auxílio ao suicídio não descaracteriza o crime, mas pode constituir uma circunstância atenuante, conforme o art. 65, III, a, CP ${ }^{98}$.

Apesar de haver divergência na doutrina a respeito do momento em que se consuma o crime de auxílio ao suicídio, é pacífico o entendimento de que só será punível se resultar em morte ou lesão corporal de natureza grave ${ }^{99}$. Assim, diferente do homicídio, o auxílio ao suicídio não admite o crime na forma de tentativa ${ }^{100}$. Divergindo desse entendimento, Bitencourt considera o crime tentado quando resulta em lesão corporal grave, mas ainda assim tal resultado é necessário para a punição de quem prestou auxílio ${ }^{101}$.

É controvertida a possibilidade do auxílio ao suicídio ser cometido por omissão. Vários doutrinadores reconhecem que o tema é polêmico, mas admitem a possibilidade do auxílio omissivo ao suicídio. Cometeria o crime quem tinha o dever jurídico de evitar o suicídio ${ }^{102}$. Nessa condição estaria o médico que assume a posição de garantidor dos pacientes sob seus cuidados. Assim, no caso de suicídio de um paciente terminal o médico que lhe prestava assistência pode responder pelo

GRECO, Rogério. Curso de direito penal: parte especial. 3. ed. Niterói: Impetus, 2007, volume 2, p. 211.

JESUS, Damásio E. de. Direito penal: parte especial. São Paulo: Saraiva, 1999, volume 2, p. 102-103 apud FRANCO, Alberto Silva; STOCO, Rui (coordenadores). Código Penal e sua interpretação jurisprudencial: parte especial. 7. ed. rev., atual. e ampl. São Paulo: Editora Revista dos Tribunais, 2001, volume 2, p. 2215.

98 MIRABETE, Julio Fabbrini. Código Penal interpretado. 5. ed. Atualizada por Renato N. Fabbrini. São Paulo: Atlas, 2005, p. 963.

99 BITENCOURT, Cezar Roberto. Tratado de direito penal: parte especial. 8. ed. rev. e atual. São Paulo: Saraiva, 2008, volume 2, p. 108-112.

CAPEZ, Fernando. Curso de direito penal: parte especial. São Paulo: Saraiva, 2003, volume 2, p. 91. GRECO, op. cit., p. 208.

MIRABETE, op. cit., p. 963.

${ }^{100}$ CAPEZ, op. cit., p. 94.

GRECO, op. cit., p. 209.

MIRABETE, op. cit., p. 963.

${ }^{101}$ BITENCOURT, op. cit., p. 108-112.

102 BITENCOURT, op. cit., p. 106.

CAPEZ, op. cit., p. 88-89.

GRECO, op. cit., p. 205-207.

MIRABETE, op. cit., p. 961. 
crime de auxílio ao suicídio, se podia evitá-lo. A mesma interpretação seria aplicável ao caso do médico responsável pela assistência a quem faz greve de fome ${ }^{103}$.

Por outro lado, a jurisprudência citada nos manuais não admite o auxílio ao suicídio na modalidade omissiva ${ }^{104}$. Há também doutrinadores, citados por Capez, que entendem que "prestar auxílio é sempre conduta comissiva" ${ }^{105}$.

${ }^{103}$ BITENCOURT, Cezar Roberto. Tratado de direito penal: parte especial. 8. ed. rev. e atual. São Paulo: Saraiva, 2008, volume 2, p. 114-115.

GRECO, Rogério. Curso de direito penal: parte especial. 3. ed. Niterói: Impetus, 2007, volume 2, p. 213;

${ }_{104}$ MIRABETE, Julio Fabbrini. Código Penal interpretado. 5. ed. Atualizada por Renato N. Fabbrini. São Paulo: Atlas, 2005, p. 962;

FRANCO, Alberto Silva; STOCO, Rui (coordenadores). Código Penal e sua interpretação jurisprudencial: parte especial. 7. ed. rev., atual. e ampl. São Paulo: Editora Revista dos Tribunais, 2001, volume 2, p. 2211-2212.

${ }^{105}$ CAPEZ, Fernando. Curso de direito penal: parte especial. São Paulo: Saraiva, 2003, volume 2, p. 89. 


\section{Capítulo 3 \\ TRATAMENTO PALIATIVO}

Tratamentos paliativos têm sido realizados no Brasil. De acordo com um levantamento recente, cerca de quarenta hospitais contam com enfermarias dedicadas a cuidados paliativos ${ }^{106}$.

Por outro lado, de acordo com Mirabete mesmo o emprego de remédios paliativos ou o acompanhamento médico sem procedimento de cura seriam puníveis pela lei penal brasileira ${ }^{107}$.

O Código Penal brasileiro não reconhece a impunibilidade do homicídio eutanásico, haja ou não o consentimento do ofendido, mas, em consideração ao motivo, de relevante valor moral, permite a minoração da pena. É punível a eutanásia propriamente dita (ação ou omissão do sujeito ativo que, por sua natureza ou intenção, causa a morte, por ação ou omissão, com a finalidade de evitar a dor) e mesmo a ortotanásia (emprego de remédios paliativos, acompanhamento médico sem procedimento de cura etc.), mas discute-se a possibilidade de não se falar em homicídio quando se interrompe uma vida mantida artificialmente por meio de aparelhos.

Barroso também considera que a administração de cuidados paliativos pode ser enquadrada como homicídio ${ }^{108}$.

A legislação penal brasileira não faz qualquer distinção entre essas categorias a que eu me referi. Assim, tanto a limitação do tratamento como a eutanásia estão sujeitas a enquadramento como crime de homicídio.

[...] Portanto um médico está sujeito a processo por crime de homicídio, seja por atuar praticando a eutanásia ou ajudando no suicídio assistido, seja por

${ }^{106}$ VIANNA, Luiz Fernando. Doentes crônicos recebem cuidados paliativos em 40 hospitais. Folha de São Paulo, 03/05/2009. Disponível em:

$<$ http://www1.folha.uol.com.br/folha/ciencia/ult306u559848.shtml> Data da consulta: 19/05/2009.

${ }_{107}$ MIRABETE, Julio Fabbrini. Manual de direito penal: parte especial (arts. 121 a 234 do CP). 24. ed. Revista e atualizada por Renato N. Fabbrini. São Paulo: Atlas, 2006, volume 2, p. 34.

${ }^{108}$ Luís Roberto Barroso é professor titular da Universidade do Estado do Rio de Janeiro.

BARROSO, Luís Roberto. Constitucionalista diz que lei ampara ortotanásia no país. Folha de São Paulo 04/12/2006. p. C4. apud BITTENCOURT, José. Projeto de Lei $n^{\circ}$ 264/2007, da Assembléia Legislativa do Estado de São Paulo. Acrescenta parágrafo ao artigo $2^{\circ}$ da Lei $n^{0} 10.241$, de 17 de março de 1999, que dispõe sobre os direitos dos usuários dos servidores e das ações de saúde no Estado e dá outras providências. Disponível em:

$<$ http://webspl1.al.sp.gov.br/internet/download?poFilelfs=9071722\&/propositura_Projetodelei_705709. doc"> Data da consulta: 01/06/2009. 
omitir tratamento, como é o caso da limitação do tratamento ou do cuidado paliativo.

No entanto, o paciente pode optar pelo tratamento paliativo e recusar outras formas de tratamento. A autonomia da vontade do paciente é discutida adiante. $\mathrm{O}$ Código Penal não autoriza o tratamento compulsório do paciente, terminal ou não, que não se encontra em situação de iminente perigo de vida.

\begin{abstract}
Em face do inciso $\mathrm{n}^{\circ}$ ॥l do $\S^{\circ}$ do art. 146, o tratamento arbitrário só é declarado lícito quando justificado por iminente perigo de vida. Não basta um simples perigo à saúde, nem um remoto ou incerto perigo de vida. Cumpre que a intervenção médica ou cirúrgica se apresente necessária, urgente, inadiável, para conjurar a iminência da morte do paciente. É preciso que exista a realidade objetiva, concreta, do perigo de vida, que certa ou muito provàvelmente, segundo a indicação científica, será debelado pelo tratamento a aplicar. Não é suficiente uma possibilidade mediata do evento letal ou condicionada a eventuais complicações. Tornase desautorizado o tratamento arbitrário mesmo nos casos em que, embora previsível a morte do enfêrmo, tenha êste um período mais ou menos prolongado de sobrevivência. ${ }^{109}$
\end{abstract}

Doença em fase terminal não significa necessariamente iminente perigo de vida. Um paciente terminal pode sobreviver por meses e mesmo dispor de uma boa qualidade de vida. $O$ tratamento paliativo enfatiza justamente o alívio do sofrimento e a promoção da qualidade de vida do paciente terminal e da família ${ }^{110}$.

Uma doença é considerada terminal quando se reconhece que não há qualquer tratamento disponível que tenha eficácia cientificamente comprovada para curar ou controlar a doença em estado avançado.

Segundo Mirabete seria punível o acompanhamento médico sem procedimento de cura ${ }^{111}$. No entanto, não se pode exigir a administração de um procedimento de cura quando não há comprovação científica da existência de um tratamento eficaz ${ }^{112}$.

${ }^{109}$ HUNGRIA, Nelson. Comentários ao código penal. 4. ed. Rio de Janeiro: Forense, 1958, volume 4, p. 179.

${ }_{110}$ BILLINGS, J. Andrew. O cuidado a pacientes terminais e às suas famílias. In: GOLDMAN, Lee; AUSIELLO, Dennis (editores). Cecil, tratado de medicina interna. Tradução da 22. ed. Tradução de Maria Angelica Borges dos Santos. Rio de Janeiro: Elsevier, 2005, volume 1, p. 15.

${ }_{111}$ MIRABETE, Julio Fabbrini. Manual de direito penal: parte especial (arts. 121 a 234 do CP). 24. ed. Revista e atualizada por Renato N. Fabbrini. São Paulo: Atlas, 2006, volume 2, p. 34.

112 HUNGRIA, Nelson. Comentários ao código penal. 4. ed. Rio de Janeiro: Forense, 1958, volume 4, p. 179. 
As técnicas de suporte de vida têm eficácia, comprovada cientificamente, para reduzir o risco de morte imediata, mas não para curar doenças terminais. Assim, resta discutir a suposta obrigatoriedade de se administrar técnicas de suporte de vida quando há iminente perigo de vida. Essa discussão é tema de outro capítulo.

\subsection{Autonomia da vontade do paciente}

A autonomia da vontade dos pacientes vem sendo reconhecida paulatinamente no ordenamento jurídico brasileiro. A Lei no 8080 , que trata da organização do Sistema Único de Saúde, estabelece em seu art. 7ํ, inciso III, que a autonomia das pessoas deve ser preservada.

Art. 7ํㅗ As ações e serviços públicos de saúde e os serviços privados contratados ou conveniados que integram o Sistema Único de Saúde (SUS), são desenvolvidos de acordo com as diretrizes previstas no art. 198 da Constituição Federal, obedecendo ainda aos seguintes princípios:

[...]

III - preservação da autonomia das pessoas na defesa de sua integridade física e moral; ${ }^{113}$

O Código Civil é mais recente e mais claro ao assegurar a autonomia do paciente. $\mathrm{O}$ art. 15, CC, proíbe que qualquer pessoa seja constrangida a submeterse a tratamento médico ou a intervenção cirúrgica.

Esse direito assegurado pela lei também foi declarado na Carta dos Direitos dos Usuários da Saúde. O texto dessa carta foi elaborado pelo Ministério da Saúde em consenso com o Conselho Nacional de Saúde e a Comissão Intergestora Tripartite. A carta ainda determina a obrigação de se fornecer adequada informação ao paciente, para que possa decidir de forma esclarecida.

O QUARTO PRINCÍPIO assegura ao cidadão o atendimento que respeite os valores e direitos do paciente, visando a preservar sua cidadania durante o tratamento.

$[\ldots]$

113 BRASIL, Lei nº 8.080, de 19/09/1990. Dispõe sobre as condições para a promoção, proteção e recuperação da saúde, a organização e o funcionamento dos serviços correspondentes e dá outras providências. Publicada no D.O.U. de 20/09/1990. 
V. Consentimento ou recusa de forma livre, voluntária e esclarecida, depois de adequada informação, a quaisquer procedimentos diagnósticos, preventivos ou terapêuticos, salvo se isso acarretar risco à saúde pública. O consentimento ou a recusa dados anteriormente poderão ser revogados a qualquer instante, por decisão livre e esclarecida, sem que the sejam imputadas sanções morais, administrativas ou legais. ${ }^{114}$

A Carta dos Direitos dos Usuários da Saúde é válida como norma infralegal, pois foi aprovada pela Portaria no 675 do Gabinete do Ministro da Saúde. Essa Portaria ainda determina que a Carta dos Direitos dos Usuários da Saúde seja afixada em local visível e de fácil acesso em todas as unidades de saúde do país, promovendo divulgação desses direitos.

Art. 1 Aprovar, na forma do Anexo a esta Portaria, a Carta dos Direitos dos Usuários da Saúde, que consolida os direitos e deveres do exercício da cidadania na saúde em todo o País.

[...]

Art. 3ำ Determinar que a Carta dos Direitos dos Usuários da Saúde seja afixada em todas as unidades de saúde, públicas e privadas, em todo o País, em local visível e de fácil acesso pelos usuários.

Essas diversas normas autorizam o paciente, devidamente esclarecido a respeito do quadro clínico e dos tratamentos disponíveis, seus riscos e benefícios, a aceitar o tratamento paliativo.

\subsection{Futilidade e obstinação terapêutica}

A literatura da área de bioética utiliza alguns conceitos como futilidade e obstinação terapêutica para justificar a decisão de administrar o tratamento paliativo e suspender a administração de outros tratamentos.

[...] um tratamento é considerado fútil quando tem poucas probabilidades de ter benefício terapêutico ${ }^{116}$.

${ }^{114}$ BRASIL, Ministério da Saúde. Carta dos Direitos dos Usuários da Saúde. Aprovada pela Portaria oㅡ 675, de 30/03/2006, do Gabinete do Ministro da Saúde, publicada no D.O.U. de 31/03/2006.

${ }_{115}$ BRASIL, Ministério da Saúde. Portaria no 675, de 30/03/2006, do Gabinete do Ministro da Saúde, publicada no D.O.U. de 31/03/2006.

${ }^{116}$ BRITO, António José dos Santos Lopes de; RIJO, José Manuel Subtil Lopes. Estudo jurídico da eutanásia em Portugal: direito sobre a vida ou dever de viver? Coimbra: Almedina, 2000, p. 34. 
A expressão "obstinação terapêutica" ( $L^{\prime}$ acharnement thérapeutique) foi introduzida na linguagem médica francesa por Jean-Robert Debray no início dos anos 50 e definida, segundo Pohier, como:

"O comportamento médico que consiste em utilizar processos terapêuticos cujo efeito é mais nocivo do que os efeitos do mal a curar, ou inútil, porque a cura é impossível e o benefício esperado é menor que os inconvenientes previsíveis $^{117}$

A utilização desses conceitos pode dificultar a compreensão do assunto. Por exemplo, ainda que sejam "poucas probabilidades de ter benefício terapêutico" o tratamento poderia ser considerado útil, e talvez a única esperança de salvar um paciente terminal. Ou conforme o ditado frequentemente utilizado nessa situação: "Enquanto existe vida existe esperança" ${ }^{118}$.

[...] Entretanto, as tentativas de médicos de recorrerem ao critério de futilidade como fundamento para interromper tratamentos têm sido assoladas por problemas. De início, alguns autores consideravam a intervenção como fútil se a probabilidade de sucesso fosse igual ou menor do que 1\%. Embora esse limite pareça ser baseado em dados empíricos, trata-se de um julgamento de valor velado. Como a declaração de futilidade visa justificar determinações unilaterais por parte dos médicos, de um modo geral ela é encarada como uma linha de argumento de defesa inadequada, que compromete a comunicação médico-paciente e viola o princípio de tomada de decisão compartilhada. A exemplo da distinção entre ordinário e extraordinário, a futilidade vem sendo crescentemente considerada um conceito que obscurece mais do que esclarece e ao qual se deve recorrer cada vez menos. ${ }^{119}$

A decisão sobre o tratamento a ser seguido deve ser compartilhada, pois cabe ao médico esclarecer quais são os tratamentos disponíveis, seus riscos e benefícios, e ao paciente a opção de recusá-los ou aceitá-los.

\subsection{Eficácia dos tratamentos médicos}

Nem todos os tratamentos médicos têm potencial de prolongar a vida. Há tratamentos que visam apenas o alívio de sintomas desagradáveis, dos quais não se

117 PESSINI, Leo. Como lidar com o paciente em fase terminal. 5. ed. rev. e atual. Aparecida: Editora Santuário, 1990, p. 47-48.

${ }_{118}$ PESSINI, op. cit., p. 17.

119 EMANUEL, Ezekiel J. Bioética na prática médica In: GOLDMAN, Lee; AUSIELLO, Dennis (editores). Cecil, tratado de medicina interna. Tradução da 22. ed. Tradução de Maria Angelica Borges dos Santos. Rio de Janeiro: Elsevier, 2005, volume 1, p. 8-9. 
espera qualquer impacto relevante sobre o tempo de vida do paciente. Os tratamentos sintomáticos são necessários para o bem estar do paciente, mas são irrelevantes quanto à tutela penal do direito à vida. Assim, a omissão de tratamento médico do qual não se espera o prolongamento da vida não configura crime contra a vida $^{120}$.

Há tratamentos médicos cuja eficácia carece de comprovação científica. $\mathrm{O}$ Conselho Federal de Medicina, a Associação Médica Brasileira e a Comissão Nacional de Residência Médica reconhecem a homeopatia e a acupuntura como especialidades médicas ${ }^{121}$. Porém, ainda não houve comprovação científica de que a homeopatia ${ }^{122}$ e a acupuntura ${ }^{123}$ sejam eficazes no tratamento de doenças. Diversos artigos científicos de revisão apontam a necessidade de se melhorar a qualidade das pesquisas que investigam a homeopatia ${ }^{124}$.

Também há tratamentos médicos cuja eficácia foi comprovada por meio de pesquisas científicas. Uma consequência da segurança a respeito da eficácia de alguns tratamentos é a necessidade de se avaliar se seria ético manter um grupo recebendo placebo nas novas pesquisas médicas. Essas pesquisas são necessárias

${ }^{120}$ GOMES, Luiz Flávio (coordenador); MOLINA, Antonio García-Pablos de. Direito penal: parte geral. São Paulo: Editora Revista dos Tribunais, 2007, volume 2, p. 291.

${ }^{121}$ CONSELHO FEDERAL DE MEDICINA, Resolução no 1634, de 11/04/2002, publicada no D.O.U. de 29/04/2002.

122 ERNST, E. A systematic review of systematic reviews of homeopathy. British Journal of Clinical Pharmacology 2002, volume 54(6), volume 577-582.

SHANG, Aijing; HUWILER-MÜNTENER, Karin; NARTEY, Linda; JÜNI, Peter; DÖRIG, Stephan; STERNE, Jonathan A.C.; PEWSNER, Daniel; EGGER, Matthias. Are the clinical effects of homoeopathy placebo effects? Comparative study of placebo-controlled trials of homoeopathy and allopathy. Lancet 2005, volume 366(9487), p. 726-732.

${ }^{123}$ DERRY, C.J.; DERRY, S.; MCQUAY, H.J.; MOORE, R.A. Systematic review of systematic reviews of acupuncture published 1996-2005. Clinical Medicine 2006, volume 6(4), p. 381-386.

124 CUCHERAT, M.;HAUGH, M.C.; GOOCH, M.; BOISSEL, J.P. Evidence of clinical efficacy of homeopathy. A meta-analysis of clinical trials. HMRAG. Homeopathic Medicines Research Advisory Group. European Journal of Clinical Pharmacology 2000, volume 56(1), p. 27-33.

KLEIJNER, Jos; KNIPSCHILD, Paul; TER RIET, Gerben. Clinical trials of homoeopathy. British Medical Journal 1991, volume 302(6772), p. 316-23.

LINDE, Klaus; MELCHART, Dieter. Randomized controlled trials of individualized homeopathy: a state-of-the-art review. The Journal of Alternative and Complementary Medicine 1998, volume 4(4), p. 371-388. 
para verificar a eficácia e a segurança dos tratamentos em condições diferentes daquelas em que foram inicialmente pesquisados ${ }^{125}$.

A medicina está em constante evolução. Os tratamentos médicos são reavaliados e frequentemente substituídos ou adaptados a melhores critérios de aplicação. Mesmo as terapias de suporte de vida são alvo de questionamento, já que os problemas relacionados aos riscos e efeitos colaterais podem superar 0 eventual benefício almejado. Como exemplo, os critérios clínicos para a transfusão de sangue têm sido revistos na literatura médica. Alguns trabalhos científicos sugerem que o uso de critérios mais restritivos na administração da transfusão sanguínea pode trazer benefícios na redução da morbidade e da mortalidade, além da redução de custos $^{126}$.

A segurança sobre a eficácia dos tratamentos médicos depende de comprovação científica. Isso não impede que sejam administrados tratamentos cuja eficácia careça de comprovação científica, já que o paciente tem o direito de consentir com o tratamento. Basta considerar que o tratamento seja suficientemente seguro e que se espere algum benefício, mesmo que seja o apenas o efeito placebo $^{127}$. Justifica-se assim a administração de tratamentos baseados em homeopatia, acupuntura, ou até mesmo placebo $^{128}$.

125 COVERDALE, John H.; MCCULLOUGH, Laurence B.; CHERVENAK, Frank A. The ethics of randomized placebo-controlled trials of antidepressants with pregnant women: a systematic review. Obstetrics \& Gynecology 2008, volume 112(6), p. 1361-1368.

HEALY, D. Ethics and science of placebo-controlled trials. Journal of Psychopharmacology 2008, volume 22(6), p. 598-599.

ZANCHETTIA, Alberto; MANCIA, Giuseppe. The dilemma of placebo controlled studies: scientific evidence, guidelines, ethics and regulatory recommendations. Journal of Hypertension 2009, volume 27(1), p. 1-2.

126 FAKHRY, Samir M.; FATA, Paola. How low is too low? Cardiac risks with anemia. Critical Care 2004, volume 8(Suppl 2), p. S11-S14.

HEBERT, Paul C.; WELLS, George; BLAJCHMAN, Morris A.; MARSHALL, John; MARTIN, Claudio; PAGLIARELLO, Giuseppe; TWEEDDALE, Martin; SCHWEITZER, Irwin; YETISIR, Elizabeth; The Transfusion Requeriments in Critical Care Investigators for the Canadian Critical Care Trials Group. A multicenter, randomized, controlled clinical trial of transfusion requirements in critical care. New England Journal of Medicine 1999, volume 340(6), p. 409-417.

127 NIES, Alan S.; SPIELBERG, Stephen P. Princípios da Terapêutica. In: HARDMAN, Joel G; LIMBIRD, Lee E (editores-chefes); MOLINOFF, Perry B.; RUDDON, Raymond W. (editores); GILMAN, Alfred Goodman (editor-consultor). Goodman \& Gilman: as bases farmacológicas da terapêutica. 9. ed. Supervisão da tradução de Penildon Silva. Rio de Janeiro: McGraw-Hill, 1996, p. 38.

${ }^{128}$ LIONE, Armand. Ethics of placebo use in clinical care. Lancet 2003, volume 362, p. 999. 
Pelo mesmo motivo, o paciente terminal pode submeter-se a um tratamento mesmo sem comprovação científica de sua eficácia em curar ou controlar a doença. Porém, a decisão sobre o tratamento a ser seguido deve ser compartilhada entre médico e paciente.

[...] o direito a recusar tratamento médico não se traduz, em contrapartida, em um direito de exigir qualquer tipo de tratamento, especialmente aqueles sem fundamentação fisiopatológica, que já não funcionaram ou que são sabidamente lesivos. ${ }^{129}$

Por fim, o paciente pode fazer a opção pelo tratamento paliativo.

\subsection{Duplo efeito da analgesia paliativa}

Analgesia corresponde ao tratamento para alívio da dor. Alguns autores preferem o termo sedação da dor.

Para Gomes e Molina a sedação paliativa consiste em evitar ou suavizar o a dor ou o sofrimento da pessoa em estado terminal por meio de medicamentos, caso em que não se antecipa o momento da morte, ao contrário do que ocorre nas demais situações que discutem (eutanásia ativa, morte assistida e ortotanásia). Entendem que não se pode vislumbrar qualquer crime (ou polêmica) na sedação paliativa, porque não há qualquer tipo de antecipação da morte ${ }^{130}$.

No entanto, o tratamento da dor severa envolve problemas técnicos inevitáveis. Além disso, não há tratamento médico totalmente seguro, isento de risco à saúde ou à vida ${ }^{131}$. "O fato de um fármaco ser útil no tratamento depende muito da

129 EMANUEL, Ezekiel J. Bioética na prática médica In: GOLDMAN, Lee; AUSIELLO, Dennis (editores). Cecil, tratado de medicina interna. Tradução da 22. ed. Tradução de Maria Angelica Borges dos Santos. Rio de Janeiro: Elsevier, 2005, volume 1, p. 8.

${ }_{130}$ GOMES, Luiz Flávio (coordenador); MOLINA, Antonio García-Pablos de. Direito penal: parte geral. São Paulo: Editora Revista dos Tribunais, 2007, volume 2, p. 291.

131 NIES, Alan S.; SPIELBERG, Stephen P. Princípios da Terapêutica. In: HARDMAN, Joel G; LIMBIRD, Lee E (editores-chefes); MOLINOFF, Perry B.; RUDDON, Raymond W. (editores); GILMAN, Alfred Goodman (editor-consultor). Goodman \& Gilman: as bases farmacológicas da terapêutica. 9. ed. Supervisão da tradução de Penildon Silva. Rio de Janeiro: McGraw-Hill, 1996, p. 31-44.

KLAASSEEN, Curtis D. Princípios de toxicologia e tratamento do envenenamento. In: HARDMAN et al., op. cit., p. 45-54. 
sua capacidade de produzir seus efeitos desejados apenas com efeitos indesejados toleráveis" ${ }^{132}$.

Os cuidados paliativos são voltados para o alívio de diversos sintomas que podem acometer os pacientes terminais e geralmente não acarretam antecipação da morte. A dor leve pode ser tratada com fármacos não opióides, com baixo risco. No entanto, o tratamento da dor moderada ou severa requer o uso de opióides, devido à sua maior eficácia no controle da dor. Com o aumento da intensidade da dor tornase necessário o uso de opióides cada vez mais fortes e em maiores doses. O uso de opióides para o controle da dor moderada ou severa em pacientes terminais é respaldado pela Organização Mundial da Saúde ${ }^{133}$.

Os fármacos opióides apresentam como efeito adverso a depressão da respiração, que ocorre mesmo em doses pequenas demais para alterar a consciência. Doses terapêuticas já causam redução de parâmetros da respiração (frequência, volume por minuto e volume corrente) e também podem provocar respiração irregular e periódica. A depressão respiratória se acentua com o aumento da dose ou com a combinação de outros medicamentos, como anestésicos gerais, tranquilizantes, ou sedativo-hipnóticos. O risco aumenta se houver disfunção pulmonar subjacente. A morte causada por opióides geralmente se deve a parada respiratória $^{134}$.

A analgesia da dor severa em paciente terminal requer a administração de opióide forte, o que acarreta perigo de morte por parada respiratória. Esse é o duplo efeito da analgesia paliativa.

\footnotetext{
132 BENET, Leslie Z. Introdução. In: HARDMAN, Joel G; LIMBIRD, Lee E (editores-chefes); MOLINOFF, Perry B.; RUDDON, Raymond W. (editores); GILMAN, Alfred Goodman (editorconsultor). Goodman \& Gilman: as bases farmacológicas da terapêutica. 9. ed. Supervisão da tradução de Penildon Silva. Rio de Janeiro: McGraw-Hill, 1996, p. 1.

${ }^{133}$ ORGANIZAÇÃO MUNDIAL DA SAÚDE. Alivio de los síntomas en el enfermo terminal. Genebra: Organização Mundial da Saúde, 1999, p. 40; 59-61; 73;

ORGANIZAÇÃO MUNDIAL DA SAÚDE. Alívio da dor no câncer. Brasília: Ministério da Saúde, 1991, $82 \mathrm{p}$.

ORGANIZAÇÃO MUNDIAL DA SAÚDE. Alivio del dolor y tratamiento paliativo en el cáncer infantil. Genebra: Organização Mundial da Saúde, 1999, 85 p.

${ }^{134}$ REISINI, Terry; PASTERNAK, Gavril. Analgésicos e antagonistas opióides. In: HARDMAN et al., op. cit., p. 386.
} 
Esse duplo efeito secundário pode mesmo ser desejado. Segundo Prado, na eutanásia indireta o médico busca a um só tempo aliviar o sofrimento do paciente e abreviar o seu curso vital, sendo este efeito secundário, derivado daquele objetivo principal. Essa conduta corresponderia ao crime de homicídio privilegiado, já que Prado não apresenta qualquer alternativa a essa imputação penal ${ }^{135}$.

Por outro lado, Branco entende que não configura a eutanásia quando o emprego da droga tiver por objetivo conter dores atrozes de paciente terminal, tornando-as realmente mais suportáveis, embora com a consequência, não diretamente querida, mas previsível, de se abreviar a vida. Considera que a eutanásia está ligada a uma ação deliberada, que tem em mira o encerramento da vida de uma pessoa que sofre de um mal terminal, padecendo de dores substanciais ${ }^{136}$.

A possibilidade de imputação penal da analgesia paliativa é pouco discutida na doutrina, que se limita à intenção do médico. Se ao administrar a analgesia paliativa o médico deseja a morte do paciente terminal como resultado, mesmo que indireto, estaria configurada a eutanásia, e portanto o homicídio privilegiado ${ }^{137}$. Se ao administrar a analgesia paliativa o médico não deseja a morte do paciente terminal como resultado, não estaria configurada a eutanásia, não haveria crime ${ }^{138}$.

No entanto, cabe ainda recorrer à analogia com outras condutas permitidas. Como já se discutiu anteriormente, o ordenamento jurídico brasileiro permite que o indivíduo assuma o risco de vida decorrente de condutas de motivação hedonista, como cirurgias estéticas e esportes violentos. Tais condutas geram risco permitido pelo Estado, que as fomenta e incentiva ${ }^{139}$. Por analogia, o paciente terminal tem o direito de aceitar a analgesia paliativa mesmo que acarrete risco de vida por parada respiratória (duplo efeito). Se qualquer um pode expor sua vida a risco para obter

\footnotetext{
135 PRADO, Luiz Regis. Curso de direito penal brasileiro: parte especial - arts. 121 a 249. 7. ed. rev. atual. e ampl. São Paulo: Editora Revista dos Tribunais, 2008, volume 2, p. 69.

${ }^{136}$ BRANCO, Paulo Gustavo Gonet. Direito à vida. In: MENDES, Gilmar Ferreira; COELHO, Inocêncio Mártires; BRANCO, Paulo Gustavo Gonet. Curso de direito constitucional. 4. ed. rev. e atual. São Paulo: Saraiva, 2009, p. 399.

${ }_{137}$ PRADO, op. cit., p. 69.

${ }^{138}$ BRANCO, op. cit., p. 399.

139 GOMES, Luiz Flávio (coordenador); MOLINA, Antonio García-Pablos de. Direito penal: parte geral. São Paulo: Editora Revista dos Tribunais, 2007, volume 2, p. 362.
} 
prazer, é justo que o paciente terminal possa expor sua vida a risco para aliviar a dor, ao receber o tratamento médico adequado para essa condição. 


\section{Capítulo 4 \\ LIMITAÇÃO DE SUPORTE DE VIDA}

Diversas interpretações da legislação brasileira poderiam autorizar a limitação de suporte de vida mediante o consentimento do paciente terminal. Outras interpretações proíbem essa conduta. Destarte, não há segurança jurídica a respeito do assunto.

\subsection{Interpretações que autorizam a limitação de suporte de vida}

Há um aparente conflito entre os dispositivos do art. 146, §3ํ, II, CP e o art. 15 , CC, pois enquanto a norma penal autoriza o constrangimento para tratamento médico em caso de iminente perigo de vida, a norma civil o proíbe:

\section{Código Penal}

Art. 146 - Constranger alguém, mediante violência ou grave ameaça, ou depois de the haver reduzido, por qualquer outro meio, a capacidade de resistência, a não fazer o que a lei permite, ou a fazer o que ela não manda: [...]

§ 3ำ - Não se compreendem na disposição deste artigo:

I - a intervenção médica ou cirúrgica, sem o consentimento do paciente ou de seu representante legal, se justificada por iminente perigo de vida; ${ }^{140}$

Art. 15. Ninguém pode ser constrangido a submeter-se, com risco de vida, a tratamento médico ou a intervenção cirúrgica. ${ }^{141}$

O aparente conflito entre esses dispositivos pode ser afastado por interpretações conforme a lei.

${ }^{140}$ BRASIL, Decreto-Lei no 2.848, de 07/12/1940. Código Penal. Publicado no D.O.U. de 31/12/1940 e retificado no D.O.U. de 03/01/1941.

${ }^{141}$ BRASIL, Lei no 10.406, de 10/01/2002. Código Civil. Publicado no D.O.U. de 11/01/2002. 


\subsubsection{Interpretação pela verificação da tipicidade conglobante}

De acordo com a doutrina de Zaffaroni o tipo penal não pode proibir o que o direito ordena e nem o que ele fomenta. Pode ocorrer que o tipo legal pareça incluir certa conduta que a própria ordem normativa ordena ou incentiva. Interpretada como parte da ordem normativa tal conduta não pode estar proibida mesmo que aparentemente esteja adequada ao tipo legal. O juízo de tipicidade não é um mero juízo de tipicidade legal, mas exige outro passo, que é a comprovação da tipicidade conglobante, consistente na averiguação da proibição através da indagação do alcance proibitivo da norma, não considerada isoladamente, e sim conglobada na ordem normativa. A tipicidade penal (adequação penal e antinormatividade) implica a tipicidade legal (adequação à formulação legal do tipo) corrigida pela tipicidade conglobante (antinormatividade), que pode reduzir o âmbito de proibição aparente surgida da consideração isolada da tipicidade legal ${ }^{142}$.

A tipicidade conglobante difere da justificação amparada pelas cláusulas de exclusão de antijuricidade. A tipicidade conglobante não surge em função de permissões que a ordem jurídica resignadamente concede, e sim em razão de mandatos ou fomentos normativos ou de indiferença (por insignificância) da lei penal. Assim, a tipicidade penal implica a contrariedade com a ordem normativa, mas não implica a antijuricidade (a contrariedade com a ordem jurídica), porque ainda pode haver uma causa de justificação (um preceito permissivo) que ampare a conduta $^{143}$.

Para o médico o dispositivo do art. 15, CC, estabelece uma ordem, um dever de não agir. O paciente dispõe de uma faculdade de agir, um direito subjetivo de recusar o tratamento médico. Porém, o médico recebe da lei uma ordem de não constrangir e tem o dever de acatar a eventual recusa do paciente ao tratamento. Como se trata de uma ordem estabelecida pela lei, é possível interpretar como conduta atípica a não administração de tratamento médico com base na recusa do

142 ZAFFARONI, Eugenio Raúl; PIERANGELI, José Henrique. Manual de direito penal brasileiro, volume 1: parte geral. 7. ed. rev. e atual. 2. tir. São Paulo: Revista dos Tribunais, 2008, p. 396 e 474.

${ }^{143}$ ZAFFARONI e PIERANGELI, op. cit., p. 397-398. 
paciente, mesmo com risco de vida, afastada a tipicidade pela análise conglobante da ordem jurídica. Essa interpretação encontra suporte de certa forma na doutrina de Pierangeli.

Apesar de reconhecer que a doutrina internacional majoritária segue orientação diferente, Pierangeli entende que a atuação do médico sem o consentimento do paciente seria justificável somente em face do consentimento presumido quando o paciente não estiver em condições de validamente consentir. Tratando dos incisos do art. 146, $3^{\circ}$, CP, Pierangeli comenta ${ }^{144}$ :

\begin{abstract}
Os dois dispositivos são bastante polêmicos. No primeiro, a expressão "sem o consentimento do paciente ou de seu representante legal" se nos afigura de duvidosa constitucionalidade, pois nenhum tratamento médico pode prescindir do consentimento do paciente e do conhecimento deste quanto aos riscos, digamos, de uma intervenção cirúrgica. Só se justifica a atuação do médico em face do consentimento presumido, ou seja, quando o paciente está sem condições de validamente consentir e se presume que, se estivesse em condições, daria o seu consentimento. E mesmo aqui o médico não pode ultrapassar os limites da necessidade, abstendo-se de outros atos. Pela exigência do prévio consentimento também é a manifestação de Paulo José da Costa Júnior. A maioria da doutrina internacional, todavia, segue a orientação do Código, que admite a atuação do médico, ainda que sem o consentimento do paciente ou de seu representante legal, desde que justificada a sua atuação por iminente perigo de vida. Mas aqui a situação é diversa, porque esse médico poderia até invocar o estado de necessidade. O que repudiamos é o tratamento arbitrário, ainda que razoável a sua necessidade, excluída a simples utilidade.
\end{abstract}

Assim, a autorização legal para "a intervenção médica ou cirúrgica, sem o consentimento do paciente ou de seu representante legal, se justificada por iminente perigo de vida" (art. 146, §3º I, CP), seria referente à ausência do consentimento por motivo alheio à vontade do paciente (por estar inconsciente, por exemplo), mas não à recusa voluntária do consentimento (direito assegurado pelo art. 15, CC). Estando em condições de expressar sua vontade, o paciente teria o direito de recusar intervenções médicas mesmo em caso de iminente perigo de vida.

No entanto, o reconhecimento da recusa a tratamento médico ainda que em caso de risco de vida como um direito subjetivo do paciente acarretaria a possibilidade de que mesmo pacientes que não padecem de doenças em fase

144 PIERANGELI, José Henrique. Manual de direito penal brasileiro: parte especial (arts. 121 a 234). São Paulo: Editora Revista dos Tribunais, 2005, p. 243. 
terminal façam uso dessa faculdade. Pacientes não terminais também podem atingir um estado de iminente perigo de vida. Porém, se a doença não é terminal, a princípio o paciente pode se recuperar e continuar vivendo, possivelmente com a cura ou o controle da doença. Tepedino cita como exemplo paradigmático a recusa à transfusão de sangue por seguidores do movimento religioso conhecido por "Testemunhas de Jeová". Porém a jurisprudência citada pelo autor é anterior à vigência do novo Código Civil ${ }^{145}$. Essa situação é diferente daquela do paciente terminal, em que o iminente perigo de vida só pode ser revertido temporariamente e no pouco tempo de vida que lhe restar ainda terá de suportar sua grave doença e sofrimento decorrente.

\subsubsection{A limitação de suporte de vida restrita a pacientes terminais}

Alguns autores admitem a limitação de suporte de vida mediante consentimento do paciente, mas entendem que esse direito subjetivo é restrito aos pacientes terminais.

Branco considera proibida a eutanásia. No entanto, entende que pode haver justificação para a suspensão de tratamentos extraordinários a um paciente terminal ou para a administração de droga para conter as dores atrozes de um paciente terminal, mesmo com a conseqüência previsível mas não querida de abreviar sua vida. Para esse autor tais hipóteses não configuram eutanásia. Já a suspensão de tratamentos ordinários, como o auxílio externo para a respiração ou a alimentação, não seriam justificados ${ }^{146}$.

Ribeiro reconhece não haver autorização legal para a eutanásia nem para o suicídio assistido no Brasil. Porém considera haver suporte legal para a suspensão do esforço terapêutico, termo que corresponde às situações nas quais pacientes em estado vegetativo persistente ou em fase terminal de doenças incuráveis autorizam

\footnotetext{
145 TEPEDINO, Gustavo (coordenador). A parte geral do novo Código Civil: estudos na perspectiva civil-constitucional. 3. ed. rev. Rio de Janeiro: Renovar, 2007, p. 51.
} 
a suspensão de tratamentos fúteis, que visam apenas adiar a morte em vez de manter a vida. Por meio de diretivas antecipadas o paciente poderia manifestar sua vontade antes de tornar-se incapaz de decisões instantes, como nos estados de inconsciência em geral ${ }^{147}$.

No Brasil, não há autorização legal para a eutanásia nem para o suicídio assistido. Mas a suspensão de esforço terapêutico está autorizada na Constituição Federal e no novo Código Civil, que permite ao paciente recusar determinados procedimentos médicos, na Lei Orgânica da Saúde (Lei no 8.080/90, artigo $7^{\circ}$, III), que reconhece o direito à autonomia do paciente, e no Código de Etica Médica, que proíbe a realização de procedimentos terapêuticos contra a vontade do paciente, fora das situações de emergência médica de salvação, o que não é o caso de doentes com quadros irreversíveis, sem nenhuma resposta a qualquer tipo de tratamento. ${ }^{148}$

Gomes e Molina sustentam que já existe base no ordenamento jurídico brasileiro e no direito internacional para se admitir a exclusão da tipicidade nos casos de limitação de suporte de vida (que denominam ortotanásia), eutanásia e morte assistida, desde que se respeite uma série de cuidados para se evitar abusos:

Com a devida vênia, discordamos dessa clássica e formalista posição da jurisprudência (e da doutrina). Para nós já existe base constitucional e legal para se admitir a exclusão da tipicidade no caso de eutanásia. ${ }^{149}$

\begin{abstract}
Lógico então, diante de tudo quanto foi exposto, que a eutanásia, a morte assistida e a ortotanásia nunca podem ser concebidas para (apenas) eliminar um paciente do hospital ou para se conseguir uma vaga na UTI ou mesmo para se diminuir custos para a rede hospitalar etc. Esses motivos transformariam o discurso da "morte digna" em uma prática de morte aberrante e reprovável (ou seja: desarrazoada). Havendo, entretanto, condições (grave sofrimento, morte irreversível, pedido consciente, anuência da família quando o caso etc.), não há como deixar de admiti-la como juridicamente possível (incensurável). Mesmo porque, nada existe contra a morte digna do ponto de vista ético (ou mesmo jurídico).

Já é hora de passar a limpo o emaranhado de paradoxos, obscuridades e preconceitos que estão circundando a questão da "morte digna" (que
\end{abstract}

${ }^{146}$ BRANCO, Paulo Gustavo Gonet. Direito à vida. In: MENDES, Gilmar Ferreira; COELHO, Inocêncio Mártires; BRANCO, Paulo Gustavo Gonet. Curso de direito constitucional. 4. ed. rev. e atual. São Paulo: Saraiva, 2009, p. 399.

${ }^{147}$ RIBEIRO, Diaulas Costa. Autonomia: viver a própria vida e morrer a própria morte. Cadernos de Saúde Pública, Rio de Janeiro, 2006, volume 22(8), p. 1749-1754.

RIBEIRO, Diaulas Costa . Eutanásia, suicídio assitido, distanásia e suspensão de esforço terapêutico. Revista Jurídica Consulex, Brasília, 2005, volume 199, p. 34-35.

${ }_{148}$ RIBEIRO, Diaulas Costa . Eutanásia, suicídio assitido, distanásia e suspensão de esforço terapêutico. Revista Jurídica Consulex, Brasília, 2005, volume 199, p. 34-35.

${ }_{149}$ GOMES, Luiz Flávio (coordenador); MOLINA, Antonio García-Pablos de. Direito penal: parte geral. São Paulo: Editora Revista dos Tribunais, 2007, volume 2, p. 371. 
compreende a eutanásia, a morte assistida e a ortotanásia). Essa delicada questão, em última análise, envolve a própria liberdade humana, tão restringida em vários momentos históricos, sobretudo quando há eclipse da autodeterminação do ser humano.

Com urgência nosso Congresso Nacional deve se debruçar sobre o assunto para que não paire dúvida sobre ele. Os médicos não podem continuar com a "espada da (in) Justiça" sobre a cabeça. Os pacientes terminais devem contar com o direito de decidir sobre a hora e local de sua morte (tal como decidiram Mário Covas, o Papa João Paulo II etc.). Necessitamos de uma legislação nacional clara e objetiva sobre a matéria. Mesmo porque, a grande maioria da população brasileira está de acordo com isso (cf. nesse sentido enquete feita pelo portal do Estadão).

De qualquer modo, mesmo sem uma legislação específica, valendo-nos da Constituição Federal vigente, do Direito internacional invocado assim como da atual teoria constitucionalista do delito (que o enfoca como uma ofensa desvaliosa ao bem jurídico), não há como reconhecer tipicidade material na "morte digna" (quando for fruto de um ato dotado de uma série enorme de condições razoáveis). ${ }^{150}$

\section{Esses autores também apresentam o seu entendimento quanto aos cuidados necessários para se evitar abusos na prática da limitação de suporte de} vida, da eutanásia ou da morte assistida:

No caso da eutanásia, v.g., a morte só pode ser considerada não abusiva quando cercada de várias cautelas: (a) que o paciente esteja padecendo "um sofrimento irremediável e insuportável"; (b) que o paciente seja informado do seu estado terminal, leia-se: não há solução médica razoável para o caso e das perspectivas (praticamente nulas) do tratamento; (c) deve haver pedido por escrito, voluntário e lúcido do paciente; (d) o médico deve ouvir a opinião de um colega (ou dois), antes de cumprir o pedido. Também é muito importante a posição da família, sobretudo quando o paciente já perdeu a consciência. De qualquer modo, só se pode falar em eutanásia, nesse caso, se o paciente, previamente, manifestou sua vontade com liberdade. A família só tem o poder de ratificar pedido anterior. Mutatis mutandis, todas essas condições são também válidas para a ortotanásia e para a morte assistida. ${ }^{151}$

Assim, Gomes e Molina consideram haver exclusão da tipicidade na limitação de suporte de vida (além de outras condutas). Uma das condições consideradas necessárias para que não ocorram abusos é que seja restrita a portadores de doenças terminais a limitação de suporte de vida. No entanto, essa exigência consta da interpretação doutrinária, mas não está positivada no ordenamento jurídico brasileiro.

${ }^{150}$ GOMES, Luiz Flávio (coordenador); MOLINA, Antonio García-Pablos de. Direito penal: parte geral. São Paulo: Editora Revista dos Tribunais, 2007, volume 2, p. 294-295.

151. GOMES e MOLINA, op. cit., p. 292-293. 


\title{
4.2 A Resolução CFM no 1.805, de 2006
}

\author{
Em novembro de 2006 o Conselho Federal de Medicina aprovou a \\ Resolução no 1805, permitindo a limitação de suporte de vida mediante o \\ consentimento do paciente terminal ou de seu representante legal. Porém a vigência \\ da resolução foi suspensa por uma decisão judicial em 30 de maio de 2008 que \\ concedeu antecipação de tutela numa ação civil pública movida pelo Ministério \\ Público Federal junto à Justiça Federal ${ }^{152}$.
}

\begin{abstract}
Art. 1o É permitido ao médico limitar ou suspender procedimentos e tratamentos que prolonguem a vida do doente em fase terminal, de enfermidade grave e incurável, respeitada a vontade da pessoa ou de seu representante legal.

$\S 11^{\circ} \mathrm{O}$ médico tem a obrigação de esclarecer ao doente ou a seu representante legal as modalidades terapêuticas adequadas para cada situação.

$\S 20$ A decisão referida no caput deve ser fundamentada e registrada no prontuário.

$\S 3^{\circ}$ É assegurado ao doente ou a seu representante legal o direito de solicitar uma segunda opinião médica.

Art. $2^{\circ} \mathrm{O}$ doente continuará a receber todos os cuidados necessários para aliviar os sintomas que levam ao sofrimento, assegurada a assistência integral, o conforto físico, psíquico, social e espiritual, inclusive assegurando-Ihe o direito da alta hospitalar. ${ }^{153}$
\end{abstract}

Na vigência da resolução houve incentivo ao debate sobre a limitação de suporte de vida na literatura médica ${ }^{154}$. No entanto, por reconhecer que o Conselho Federal de Medicina não é um órgão legislativo, ainda se clamava pela modificação

152 BRASIL. Decisão interlocutória proferida na ação civil pública no 2007.34.00.014809-3, Brasília: 14a Vara Federal, da Seção Judiciária do Distrito Federal, 30/05/2008. Disponível em: <http://processual-df.trf1.gov.br/Processos/ProcessosSecaoOra/ConsProcSecaoPub.php?SECAO= DF\&proc $=200734000148093 \& \mathrm{sec}=3400 \& \operatorname{var}=14 \& \mathrm{dtp}=30 / 05 / 2008 \& \mathrm{mat}=393 \& \mathrm{tpb}=2 \& \mathrm{seq}=13>$ Data da consulta: 03/06/2009.

${ }^{153}$ CONSELHO FEDERAL DE MEDICINA, Resolução nํ 1805, de 09/11/2006, publicada no D.O.U. de 28/11/2006.

154 LAGO, Patrícia M.; DEVICTOR, Denis; PIVA, Jefferson; BERGOUNIOUX, Jean. End-of-life care in children: the Brazilian and the international perspectives. Jornal de Pediatria 2007, volume 83(2Supl.), p. S109-S116.

SOARES, Márcio; TERZI, Renato G.G.; PIVA, Jefferson P. Série temática - Terminalidade da vida e cuidados de final de vida na unidade de terapia intensiva. Revista Brasileira de Terapia Intensiva 2007, volume 19(3), p. 357-358.

LAGO, Patrícia Miranda; GARROS, Daniel; PIVA, Jefferson P. Terminalidade da vida e cuidados de final de vida na unidade de terapia intensiva pediátrica. Revista Brasileira de Terapia Intensiva 2007, volume 19(3), p. 359-363. 
da legislação federal brasileira para que também autorizasse a limitação de suporte de vida ${ }^{155}$

A resolução estava em conformidade com a doutrina de Gomes e Molina, pois restringia a limitação de suporte de vida aos pacientes terminais. No entanto, mesmo durante sua vigência, esses autores observaram que a questão continuava gerando muitas controvérsias, pois a referida resolução não tinha força de lei ${ }^{156}$.

Ainda é aguardada a decisão final do processo em que se julga a validade da Resolução CFM no 1.805.

\subsection{Legislações locais}

Em 1999 uma lei no Estado de São Paulo permitiu aos usuários dos serviços de saúde recusar tratamentos dolorosos ou extraordinários para prolongar a vida, além de poder optar pelo local da morte. A Lei foi sancionada pelo Governador Mário Covas, que naquela época já sabia ser portador de um câncer. A Lei no 10.241 do Estado de São Paulo ficou conhecida como Lei Mário Covas ${ }^{157}$. Na fase terminal da doença Mário Covas optou por sair do hospital e aguardar pela morte em casa ${ }^{158}$.

Artigo $2^{\circ}$ - São direitos dos usuários dos serviços de saúde no Estado de São Paulo:

$[\ldots]$

XXIII - recusar tratamentos dolorosos ou extraordinários para tentar prolongar a vida; e

XXIV - optar pelo local de morte. ${ }^{159}$

${ }^{155}$ SOARES, Márcio; TERZI, Renato G.G.; PIVA, Jefferson P. End-of-life care in Brazil. Intensive Care Medicine 2007, volume 33, p. 1015.

${ }^{156}$ GOMES, Luiz Flávio (coordenador); MOLINA, Antonio García-Pablos de. Direito penal: parte geral. São Paulo: Editora Revista dos Tribunais, 2007, volume 2, p. 292.

${ }_{157}$ TEODORO, Plínio. Lei criada por Mário Covas permite ortotanásia em São Paulo desde 1999. O Globo 10/11/2006. Disponível em: <http://oglobo.globo.com/pais/mat/2006/11/10/286601451.asp> Data da consulta: 08/06/2009.

${ }^{158}$ SCHELP, Diogo. Até onde prolongar a vida: Como médicos e familiares decidem se devem ou não suspender os chamados tratamentos fúteis, que apenas mantêm vivos doentes para os quais não há esperança de cura. Veja 04/09/2002. Disponível em:

<http://veja.abril.com.br/040902/p_082.html> Data da consulta: 24/04/2009.

159 ESTADO DE SÃO PAULO, Lei no 10.241, de 17/03/1999, do Estado de São Paulo. Dispõe sobre os direitos dos usuários dos serviços e das ações de saúde no Estado e dá outras providências. Disponível em:

<http://www.al.sp.gov.br/repositorio/legislacao/lei/1999/lei\%20n.10.241,\%20de\%2017.03.1999.htm> 


\section{Em 2001 os mesmos direitos foram estabelecidos para os usuários dos} serviços de saúde do Distrito Federal, por meio de uma lei distrital.

Art. $2^{\circ}$ São direitos dos usuários dos serviços de s aúde no Distrito Federal: $[\ldots]$ XXI - recusar tratamentos dolorosos ou extraordinários para tentar prolongar a vida; e XXII - optar pelo local de morte. ${ }^{160}$

Direitos similares foram estabelecidos por meio de leis estaduais no Rio de Janeiro $^{161}$, Pernambuco ${ }^{162}$, Mato Grosso ${ }^{163}$ e Roraima ${ }^{164}$, e por meio de leis municipais em Marília ${ }^{165}$, Belo Horizonte ${ }^{166}$ e São Paulo ${ }^{167}$.

Data da consulta: 25/05/2009.

160 DISTRITO FEDERAL, Lei oํ 2.804, de 25/10/2001, do Distrito Federal. Dispõe sobre os direitos dos usuários dos serviços e das ações de saúde no Distrito Federal. Publicada no D.O.D.F. de 07/11/2001.

Disponível em: <http://www.cl.df.gov.br/Legislacao/buscarLei-2181!buscarLei.action>

Data da consulta: 25/05/2009.

${ }^{161}$ ESTADO DO RIO DE JANEIRO, Lei oㅜ 3.613, de 25/10/2001, do Estado do Rio de Janeiro. Dispõe sobre os direitos dos usuários dos serviços e das ações de saúde no Estado do Rio de Janeiro e dá outras providências. Disponível em:

<http://alerjln1.alerj.rj.gov.br/CONTLEI.NSF/b24a2da5a077847c032564f4005d4bf2/1ad0f379285f3c05 03256a9a0050a557?OpenDocument>

Data da consulta: 25/05/2009.

${ }_{162}$ ESTADO DE PERNAMBUCO, Lei no 12.770 , de 08/03/2005, do Estado de Pernambuco. Dispõe sobre os direitos dos usuários dos serviços e das ações de saúde no Estado e dá outras providências. Disponível em: <http://legis.alepe.pe.gov.br/legis_inferior_norma.aspx?cod=LE12770> Data da consulta: 25/05/2009.

163 ESTADO DO MATO GROSSO, Lei Complementar no 283, de 09/10/2007, do Estado do Mato Grosso. Modifica o inciso IV e acrescenta Parágrafo único ao Art. $4^{\circ}$ da Lei Complementar $n^{\circ}$ 22, de 09 de novembro de 1992. Disponível em:

<http://www.al.mt.gov.br/v2008/Raiz\%20Estrutura/Leis/admin/ssl/ViewPrincipal2.asp?page=lc283.htm Data da consulta: 25/05/2009.

${ }^{164}$ ESTADO DE RORAIMA, Lei no 687, de 17/10/2008, do Estado de Roraima. Dispõe sobre a cartilha dos Direitos do paciente. Disponível em:

<http://www.al.rr.gov.br/publico/setores/000/2/download/Leis\%202008/Lei\%20nㅇ\%20687\%20de\%201

7.10.08.pdf > Data da consulta: 28/06/2009.

${ }^{165}$ MUNICÍPIO DE MARÍLIA, Lei № 5.280, de 13/09/2002, do Município de Marília. Dispõe sobre os direitos dos usuários dos serviços e as ações de saúde no Município e dá outras providências. Texto no arquivo "Arquivo-_5280.pdf", disponível a partir de:

<http://www.camar.sp.gov.br/novo/index2.php?pag=leisano\&ano=2002\&idtipolei=1\&pg=11> Data da consulta: 26/05/2009.

${ }_{166}$ MUNICÍPIO DE BELO HORIZONTE, Lei no 8.926, de 02/08/2004, do Município de Belo Horizonte. Dispõe sobre os direitos do usuário dos serviços e das ações de Saúde, no Município. Texto no arquivo "lei8926-cons.doc", disponível a partir de:

$<$ http://www.cmbh.mg.gov.br/index.php?option=com_wrapper\&ltemid=580>

Data da consulta: 25/05/2009.

${ }_{167}$ MUNICÍPIO DE SÃO PAULO, Lei no 14.413, de 31/05/2007, do Município de São Paulo. Dispõe sobre os direitos dos usuários dos serviços e das ações de saúde no Município e dá outras providências. Pesquisa do texto da lei disponível a partir de: 


\subsubsection{Comparações entre leis estaduais e municipais}

Quanto aos direitos de optar pelo local de morte e de recusar tratamentos dolorosos ou extraordinários para tentar prolongar a vida, as leis municipais de São Paulo e de Marília são redundantes em relação à lei estadual, pois possuem dispositivos similares aos incisos XXIII e XXIV do artigo $2^{\circ}$ da Lei $n^{\circ} 10.241$ do Estado de São Paulo.

No Estado de Minas Gerais é mais complexa a situação das leis que tratam dos direitos dos usuários dos serviços e das ações de saúde. O projeto de lei no 2 de 2003, da Assembléia Legislativa do Estado de Minas Gerais, continha dispositivos similares à lei paulista, que autorizariam a opção pelo local de morte e o direito de recusar tratamentos dolorosos ou extraordinários para tentar prolongar a vida ${ }^{168}$. Porém, durante o processo legislativo foram propostas emendas modificando ou suprimindo tais dispositivos ${ }^{169}$. O inciso XXI, que permitiria a opção pelo local de morte foi suprimido do projeto de lei. Outros incisos foram modificados para não se permitir a recusa ao tratamento em caso de iminente perigo de vida. A Lei oㅜ 16.279 do Estado de Minas Gerais foi aprovada com as alterações propostas nas emendas.

Art. ํo - São direitos do usuário dos serviços de saúde no Estado:

$[\ldots]$

VII - consentir ou recusar, de forma livre, voluntária e esclarecida, com adequada informação, ser submetido a procedimentos diagnósticos ou terapêuticos, salvo em caso de iminente perigo de vida; $[\ldots]$

<http://www3.prefeitura.sp.gov.br/cadlem/secretarias/negocios_juridicos/cadlem/pesqnumero.asp?> Data da consulta: 25/05/2009.

168 ASSEMBLÉIA LEGISLATIVA DO ESTADO DE MINAS GERAIS, Projeto de Lei ํㅜ 2/2003. Disponível em:

$<$ http://hera.almg.gov.br/cgi-bin/nph-brs?d=MATE\&co1=e\&p=1\&u=http://www.almg.gov.br/mate/cham a_pesquisa.asp\&SECT1=IMAGE\&SECT2=THESOFF\&SECT3=PLUROFF\&SECT6=BLANK\&SECT7= LINKON\&I=20\& $r=1 \& f=L 3 ; 1 ;(P L .20030000201$ [codi]) [txmt];all;mate\&s1=LEI+adj+16279+adj+2006.nor $\mathrm{m} . \& s 2=$ remissivo\&SECT8=TODAPROP>

Data da consulta: 26/05/2009.

169 ASSEMBLÉIA LEGISLATIVA DO ESTADO DE MINAS GERAIS, Emendas ao Projeto de Lei no 2/2003. Disponível em:

$<$ http://hera.almg.gov.br/cgi-bin/nph-

brs?d=MATE\&co1=e\&p=1\&u=http://www.almg.gov.br/mate/chama_pesquisa.asp\&SECT1=IMAGE\&S ECT2=THESOFF\&SECT3=PLUROFF\&SECT6=BLANK\&SECT7=LINKON\&I=20\& $r=1 \& f=L 3 ; 1 ;(P L .200$ 300002061 [codi]] [txmt];all;mate\&s1=LEI+adj+16279+adj+2006.norm.\&s2=remissivo\&SECT8=TODAP $\mathrm{ROP}>$

Data da consulta: 26/05/2009. 
XX - recusar tratamento doloroso ou extraordinário. ${ }^{170}$

No Município de Juiz de Fora foi vetado o inciso XXII do artigo $2^{\circ}$ da Lei $n^{\circ}$ 11.642, que autorizaria o direito de recusar tratamentos dolorosos ou extraordinários para tentar prolongar a vida ${ }^{171}$. $O$ veto foi motivado pelo receio de tratar dessa questão polêmica que poderia levar à discussão sobre a eutanásia e pelo receio de contrariar normas federais e estaduais, dentre as quais a Lei ํㅜ 16.279 do Estado de Minas Gerais ${ }^{172}$. No entanto, a lei municipal permite a opção pelo local de morte (art. $2^{\circ}$, XXV, da Lei ํㅜ 11.642, do Município de Juiz de Fora). As razões do veto não versaram sobre a possibilidade do paciente optar por morrer fora do ambiente hospitalar como forma de recusar tratamento na iminência da morte, o que também poderia contrariar a lei estadual mineira.

No caso de Belo Horizonte o conflito de normas é mais evidente. A Lei ํㅡ 8.926, do Município de Belo Horizonte, contém dispositivos que autorizam a opção pelo local de morte (art. $2^{\circ}$, XXIV) e o direito de recusa a tratamento doloroso ou extraordinário na tentativa de prolongamento da vida (art. $2^{\circ}$, XXIV) ${ }^{173}$. Aparentemente há conflito entre essa lei municipal e a Lei ㄲo 16.279 do Estado de Minas Gerais, que não permite a recusa a tratamento quando o perigo de vida é iminente.

\footnotetext{
${ }^{170}$ ESTADO DE MINAS GERAIS, Lei no 16.279, de 20/07/2006, do Estado de Minas Gerais. Dispõe sobre os direitos dos usuários das ações e dos serviços de saúde no Estado. Disponível em: $<$ http://hera.almg.gov.br/cgi-bin/nph-brs?d=NJMG\&f=G\&l=20\&n=\&p=1\&r=1\&u=http://www.almg.gov.br /njmg/chama_pesquisa.asp\&SECT1=IMAGE\&SECT2=THESOFF\&SECT3=PLUROFF\&SECT6=HITIM G\&SECT7=LINKON\&SECT8=DIRINJMG\&SECT9=TODODOC\&CO1=E\&CO2=E\&CO3=E\&s1=\&s2=1627 $9 \& s 3=\& s 4=>$ Data da consulta: 26/05/2009.

${ }^{171}$ CÂMARA MUNICIPAL DE JUIZ DE FORA, Lei ํㅜ 11.642, de 22/07/2008. Dispõe sobre os direitos do usuário dos serviços e das ações de Saúde, no Município de Juiz de Fora. Disponível em: <http://isal.camarajf.mg.gov.br/scripts/salpxnjur.dll/njn?njt=LEI\&njn=11642\&njc=> Data da consulta: 26/05/2009.

${ }^{172}$ CÂMARA MUNICIPAL DE JUIZ DE FORA, Razão de Veto ao Projeto de Lei no 7/2008. Disponível em:

$<$ http://isal.camarajf.mg.gov.br/scripts/salpx.dll/plti?pla=2008\&plt=PLEl\&pln=000007\&pls=16\&pld=\%2 $0-\% 20$ Projeto\%20de\%20Lei\&plp=5212-00/2006>

Data da consulta: 26/05/2009.

${ }^{173}$ MUNICÍPIO DE BELO HORIZONTE, Lei no 8.926, de 02/08/2004, do Município de Belo Horizonte. Dispõe sobre os direitos do usuário dos serviços e das ações de Saúde, no Município. Texto no arquivo "lei8926-cons.doc", disponível a partir de:

$<$ http://www.cmbh.mg.gov.br/index.php?option=com_wrapper\&ltemid=580>

Data da consulta: 25/05/2009.
} 


\subsubsection{Tratamentos ordinários e extraordinários.}

As normas locais citadas autorizam o paciente recusar "tratamentos extraordinários para tentar prolongar a vida". Resta saber quais são os tratamentos considerados extraordinários e quais são os ordinários.

Dos doutrinadores pesquisados, somente Branco abordou esse tema, dando sua opinião pessoal de que considera como tratamentos ordinários o auxílio externo para a respiração e a alimentação, e que portanto não podem ser retirados ${ }^{174}$.

Os autores da área de bioética não esclarecem quais das técnicas de suporte de vida são extraordinárias ou ordinárias. Pessini sugere como critérios para classificar como ordinário ou extraordinário: benefício razoável, gasto excessivo, dor e outros inconvenientes ${ }^{175}$.

Outros autores alertam que a terminologia meios ordinários e extraordinários é superada, utilizando-se em seu lugar uma nova categoria conceitual, a dos meios proporcionais e desproporcionais. Porém, não também não definem quais técnicas de suporte de vida são proporcionais e desproporcionais. Limitam-se a elencar diversos critérios vagos e confusos que poderiam ser utilizados na tentativa de defini-los ${ }^{176}$. A literatura médica recomenda que se deixe de usar esses termos ${ }^{177}$.

Em resumo, o termo "tratamentos extraordinários para tentar prolongar a vida" não tem uma definição precisa sequer na literatura especializada. A falta de clareza do termo dá margem a opiniões pessoais e arbitrárias.

174 BRANCO, Paulo Gustavo Gonet. Direito à vida. In: MENDES, Gilmar Ferreira; COELHO, Inocêncio Mártires; BRANCO, Paulo Gustavo Gonet. Curso de direito constitucional. 4. ed. rev. e atual. São Paulo: Saraiva, 2009, p. 399.

${ }^{175}$ DRANE, James F. El cuidado del enfermo terminal. Ética clínica y recomendaciones prácticas paras instituciones de salud y servicios de cuidados domiciliarios. Washington: Organização Panamericana da Saúde, 1999, p. 153-168.

PESSINI, Leo. Como lidar com o paciente em fase terminal. 5. ed. rev. e atual. Aparecida: Editora Santuário, 1990, p. 36-52.

${ }^{176}$ DRANE, op. cit., p. 16-19.

SOARES, André Marcelo M.; PINHO, João Carlos de. Questões bioéticas relativas ao final da vida. In: MOSER, Antônio; SOARES, André Marcelo M. Bioética: do consenso ao bom senso. Petrópolis: Vozes, 2006, p. 145. 


\subsubsection{Natureza jurídica das normas locais autorizadoras}

Essas normas locais citadas podem servir como fundamento para que não configure crime a limitação de suporte de vida mediante o consentimento do paciente. A existência de uma norma que autoriza a conduta permite suscitar hipóteses de atipicidade ou de exclusão de antijuricidade, pelo exercício regular do direito ou pelo estrito cumprimento do dever legal.

Pelas teses de atipicidade, a conduta autorizada por lei não pode ser considerada fato típico, ou seja, não configura crime. A doutrina da tipicidade conglobante de Zaffaroni ${ }^{178}$ foi discutida anteriormente em relação à legislação federal. As normas locais citadas também estabelecem direitos subjetivos para os pacientes, cujas decisões devem ser respeitadas pelos médicos. Como essas normas locais geram para o médico o dever de agir conforme a decisão do paciente, a conduta do médico conforme a norma não pode ser considerada proibida. Deve ser considerada atípica pela verificação da tipicidade conglobante.

Gomes e Molina defendem ainda outra tese de atipicidade. Consideram que está excluída a tipicidade material dos resultados decorrentes das condutas fomentadas pelo direito, porque tais atividades geram riscos permitidos. Se o risco é permitido não há desaprovação da conduta. Não seria racional que o Estado proíba o que ele mesmo fomenta e incentiva ${ }^{179}$.

Assim, pode se levantar a hipótese de que se a lei local autoriza o paciente a recusar tratamentos dolorosos ou extraordinários para tentar prolongar a vida, não pode ser tida como fato típico a conduta do médico que acatar a decisão do paciente.

177 EMANUEL, Ezekiel J. Bioética na prática médica In: GOLDMAN, Lee; AUSIELLO, Dennis (editores). Cecil, tratado de medicina interna. Tradução da 22. ed. Tradução de Maria Angelica Borges dos Santos. Rio de Janeiro: Elsevier, 2005, volume 1, p. 8-9.

178 ZAFFARONI, Eugenio Raúl; PIERANGELI, José Henrique. Manual de direito penal brasileiro, volume 1: parte geral. 7. ed. rev. e atual. 2. tir. São Paulo: Revista dos Tribunais, 2008, p. 396-398.

${ }^{179}$ GOMES, Luiz Flávio (coordenador); MOLINA, Antonio García-Pablos de. Direito penal: parte geral. São Paulo: Editora Revista dos Tribunais, 2007, volume 2, p. 362. 
Também pode se levantar hipóteses de exclusão de ilicitude com base nas leis locais citadas. Como esse assunto ainda não foi tratado pelos doutrinadores, recorremos ao emprego da analogia com o aborto em caso de gravidez resultante de estupro, também denominado aborto sentimental.

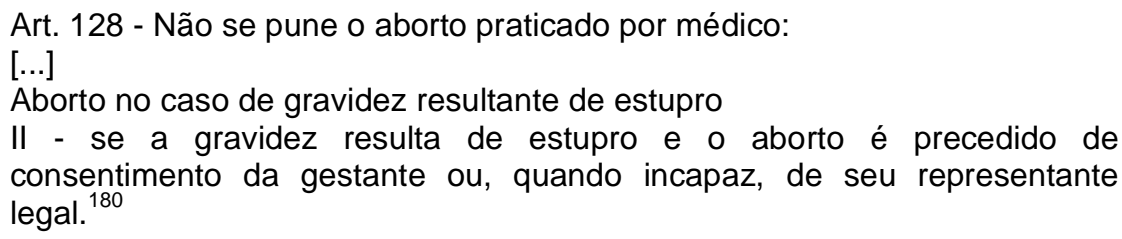

A permissão legal para a realização de aborto com o consentimento da vítima em caso de gestação decorrente de estupro guarda certa similaridade com a limitação de suporte de vida mediante o consentimento do paciente. Em ambos casos há conflito de dois bens jurídicos tutelados pela lei penal, um dos quais a vida humana. No caso do aborto sentimental o outro bem jurídico em conflito pode ser considerado a saúde psicológica ${ }^{181}$ ou a liberdade de autodeterminação da mulher $^{182}$. No caso da limitação de suporte de vida o outro bem jurídico em conflito pode ser considerado a dignidade da pessoa humana ou o direito de não ser submetido a tratamento desumano ${ }^{183}$.

Para Marques o aborto consentido no caso de gravidez resultante de estupro é um direito subjetivo e sua prática constitui exercício regular de direito ${ }^{184}$. Prado, citando Patrícia Laurenzo Copello, também apresenta uma tese em que se considera existir um direito de agir do médico, quando a paciente consente com o aborto em caso de gestação decorrente de estupro.

Indaga-se qual a natureza da indicação ética em estudo. Sustenta-se, por um lado, que a conduta do médico e de sua equipe é lícita, com base na ampliação do âmbito da eximente do exercício regular de um direito (art. 23,

\footnotetext{
${ }^{180}$ BRASIL, Decreto-Lei no 2.848, de 07/12/1940. Código Penal. Publicado no D.O.U. de 31/12/1940 e retificado no D.O.U. de 03/01/1941.

${ }^{181}$ CAPEZ, Fernando. Curso de direito penal: parte especial. São Paulo: Saraiva, 2004, volume 2, p. 124.

${ }^{182}$ PRADO, Luiz Regis. Curso de direito penal brasileiro: parte especial - arts. 121 a 249. 7. ed. rev. atual. e ampl. São Paulo: Editora Revista dos Tribunais, 2008, volume 2, p. 116.

${ }^{183}$ RIBEIRO, Diaulas Costa. Autonomia: viver a própria vida e morrer a própria morte. Cadernos de Saúde Pública, Rio de Janeiro, 2006, volume 22(8), p. 1749-1754.

${ }^{184}$ MARQUES, José Frederico. Tratado de direito penal. 1. ed. atual. Campinas: Bookseller, 1997, volume 2, p. 178-179.
} 
III, CP). Todavia, exige-se, para a licitude da intervenção cirúrgica, o consentimento da gestante ou de seu representante legal. É indispensável o consentimento para a justificação da conduta do médico. Logo, mais do que um mero requisito, o consentimento constitui a autêntica base da eximente, pois "é precisamente a conformidade do paciente que faz surgir o direito de agir do médico. $E$ isso é assim porque, na verdade, todo tratamento médico implica ingerência em bens jurídicos do paciente, ingerência que só se justifica se o próprio lesado - ou seu representante legal - o autorizam". ${ }^{18}$

Recorrendo à analogia pode se levantar a hipótese de que se o paciente recusa tratamentos dolorosos ou extraordinários para tentar prolongar a vida, amparado pela lei local, surge para o médico um direito de agir conforme a decisão do paciente. Haveria exclusão da ilicitude na conduta do médico, posto tratar-se de um exercício regular do direito.

Exclusão de ilicitude

Art. 23 - Não há crime quando o agente pratica o fato:

[...]

III - em estrito cumprimento de dever legal ou no exercício regular de direito. ${ }^{186}$

Por outro lado, foram encontrados acórdãos em que se afirma que um homicídio não pode ser justificado com base em um suposto exercício regular de direito, mas foram proferidos antes da criação das normas locais em discussão ${ }^{187}$. Não foi encontrada jurisprudência a respeito das leis locais citadas.

Gomes e Molina entendem o médico funcionário público tem o dever de fazer o aborto no caso de gravidez resultante de estupro, desde que haja consentimento da gestante ${ }^{188}$. Porém esse posicionamento é menos abrangente que a que trata do exercício regular do direito, pois se refere apenas aos médicos funcionários públicos, que ainda podem recusar o atendimento pessoal valendo-se de uma objeção de consciência. Uma norma técnica do Ministério da Saúde garante

\footnotetext{
185 PRADO, Luiz Regis. Curso de direito penal brasileiro: parte especial - arts. 121 a 249. 7. ed. rev. atual. e ampl. São Paulo: Editora Revista dos Tribunais, 2008, volume 2, p. 116.

186 BRASIL, Decreto-Lei № 2.848, de 07/12/1940. Código Penal. Redação modificada pela Lei no 7.209, de 11/07/1984, publicada no D.O.U. de 13/07/1984.

${ }^{187}$ MINAS GERAIS, $2^{\underline{a}}$ Câmara Criminal do Tribunal de Justiça de Minas Gerais, Apelação 20.217, relator Desembargador Aníbal Pacheco, 01/10/1987, Revista dos Tribunais, volume 628, p. 352.

MINAS GERAIS, 2ª ${ }^{-}$Câmara Criminal do Tribunal de Justiça de Minas Gerais, Apelação 39.268-8, relator Desembargador Guido de Andrade, 01/06/1995, DJ 25/06/1996, Revista dos Tribunais, volume 736, p. 676.

${ }^{188}$ GOMES, Luiz Flávio (coordenador); MOLINA, Antonio García-Pablos de. Direito penal: parte geral. São Paulo: Editora Revista dos Tribunais, 2007, volume 2, p. 363.
} 
ao médico a objeção de consciência nesse caso, ou seja, o direito de recusa em realizar o abortamento em casos de gravidez resultante de violência sexual. No entanto, é dever do médico garantir a atenção ao abortamento por outro profissional da instituição ou de outro serviço. $A$ atuação do médico torna-se obrigatória se não houver outro médico que o faça ou quando sua omissão resulte em risco para a paciente ${ }^{189}$.

Recorrendo à analogia pode se levantar a hipótese de que quando o paciente recusa tratamentos dolorosos ou extraordinários para tentar prolongar a vida, surge para o médico o dever de acatar a decisão do paciente, com base no dispositivo da lei local aplicável. Haveria exclusão da ilicitude na conduta do médico, posto tratar-se de estrito cumprimento de dever legal. Essa hipótese é mitigada pela possibilidade do médico se valer de uma objeção de consciência.

Greco rejeita as hipóteses justificadoras do exercício regular de direito e do estrito cumprimento do dever legal no caso do aborto sentimental. Considera tratarse de uma hipótese de inexigibilidade de conduta diversa, não se podendo exigir da gestante que sofre a violência sexual a manutenção da gravidez, razão pela qual, optando-se pelo aborto, o fato será típico e ilícito, mas deixará de ser culpável ${ }^{190}$. Esse posicionamento não é suficiente para se estabelecer a analogia pretendida, pois o autor não tece comentário a respeito da natureza jurídica da conduta do médico que realiza o aborto, mas apenas a respeito da conduta da gestante.

A pluralidade de teses apresentadas decorre da falta de posicionamento na doutrina e na jurisprudência a respeito da possível natureza jurídica das leis locais que permitem ao paciente recusar tratamentos dolorosos ou extraordinários para tentar prolongar a vida e a optar pelo local de morte.

\footnotetext{
189 BRASIL. Ministério da Saúde. Secretaria de Atenção à Saúde. Departamento de Ações Programáticas Estratégicas. Área Técnica de Saúde da Mulher. Prevenção e Tratamento dos Agravos Resultantes da Violência Sexual contra Mulheres e Adolescentes: norma técnica. 2. ed. atual. e ampl. Brasília: Ministério da Saúde, 2005, p. 45-46.

Disponível em: <http://portal.saude.gov.br/portal/arquivos/pdf/norma_prevencao_atualizada.pdf> Data da consulta 03/06/2009.

${ }_{190}$ GRECO, Rogério. Curso de direito penal: parte especial. 3. ed. Niterói: Impetus, 2007, volume 2, p. 255.
} 
Por fim, adotando-se quaisquer das interpretações de que o ordenamento jurídico federal autoriza a limitação de suporte de vida, as diversas leis locais citadas estariam apenas declarando um direito já existente para os usuários dos serviços de saúde.

\subsubsection{Constitucionalidade das leis locais autorizadoras}

Ao pedir a revogação da Resolução CFM № 1.805, Oliveira levantou suspeita de inconstitucionalidade sobre a Lei oㅜ 10.241 do Estado de São Paulo. No entanto, admitiu que incidente de inconstitucionalidade ainda não foi suscitado ${ }^{191}$.

Barroso entende que uma interpretação ortodoxa, tradicional, concluiria pela inconstitucionalidade das leis estaduais citadas, pois os Estados não têm competência para legislar sobre direito penal ${ }^{192}$.

No entanto, as normas locais citadas não tem por objeto o direito penal. A doutrina reconhece que as leis extrapenais podem autorizar condutas que então deixam de configurar crime, pela cláusula de exclusão de ilicitude do exercício regular do direito ${ }^{193}$.

A antijuricidade tem como substractum o conflito do fato típico com a ordem jurídica. Se determinada ação ou omissão, apesar de enquadrável num tipo

\footnotetext{
191 OLIVEIRA, Wellington Divino Marques de. Petição inicial da ação civil pública no 2007.34.00.014809-3, da 14ํㅜ Vara Federal, da Seção Judiciária do Distrito Federal. Brasília: Ministério Público Federal, 2007, p. 114. Disponível em: <http://noticias.pgr.mpf.gov.br/noticias-dosite/pdfs/ACP\%20Ortotanasia.pdf> Data da consulta: 03/06/2009.

192 BARROSO, Luís Roberto. Constitucionalista diz que lei ampara ortotanásia no país. Folha de São Paulo 04/12/2006. p. C4. apud BITTENCOURT, José. Projeto de Lei nº 264/2007, da Assembléia Legislativa do Estado de São Paulo. Acrescenta parágrafo ao artigo $2^{\circ}$ da Lei no 10.241 , de 17 de março de 1999, que dispõe sobre os direitos dos usuários dos servidores e das ações de saúde no Estado e dá outras providências. Disponível em:

<http://webspl1.al.sp.gov.br/internet/download?poFilelfs=9071722\&/propositura_Projetodelei_705709. doc"> Data da consulta: 01/06/2009.

${ }^{193}$ HUNGRIA, Nelson. Comentários ao código penal. 4. ed. Rio de Janeiro: Forense, 1958, volume 1, tomo 2, p. 310.

MARQUES, José Frederico. Tratado de direito penal. 1. ed. atual. Campinas: Bookseller, 1997, volume 2, p. 177-180.

GRECO, Rogério. Curso de direito penal: parte geral. 7. ed. Niterói: Impetus, 2006, volume 1, p. 401. NORONHA, Edgard Magalhães. Direito penal. 12. ed. São Paulo: Saraiva, 1973, volume 1, p. 196.

CAPEZ, Fernando. Curso de direito penal: parte geral. 4. ed. rev. e atual. São Paulo: Saraiva, 2002, volume 1, p. 260-261.
} 
delituoso, consubstancia uma facultas agendi que promana de norma jurídica contida em lei não penal - é evidente que tal conduta não é ilícita porque se harmoniza com os imperativos do direito objetivo. ${ }^{194}$

As normas locais citadas tratam da proteção e defesa da saúde, pois têm como objeto os direitos dos usuários dos serviços de saúde. No âmbito federal esses direitos foram declarados por meio da Carta dos Direitos dos Usuários da Saúde, aprovada pela Portaria № 675 do Gabinete do Ministro da Saúde ${ }^{195}$. A ausência de lei federal a respeito dos direitos dos usuários dos serviços de saúde permite que leis estaduais e distritais ou até mesmo municipais tratem do assunto.

Art. 24. Compete à União, aos Estados e ao Distrito Federal legislar concorrentemente sobre:

[...]

XII - previdência social, proteção e defesa da saúde;

$[\ldots]$

$\S 1^{\circ}$ - No âmbito da legislação concorrente, a competência da União limitarse-á a estabelecer normas gerais.

$\S 2^{\circ}$ - A competência da União para legislar sobre normas gerais não exclui a competência suplementar dos Estados.

$\S 3^{\circ}$ - Inexistindo lei federal sobre normas gerais, os Estados exercerão a competência legislativa plena, para atender a suas peculiaridades.

$\S 4^{\circ}$ - A superveniência de lei federal sobre normas gerais suspende a eficácia da lei estadual, no que Ihe for contrário.

[...]

Art. 30. Compete aos Municípios:

I - legislar sobre assuntos de interesse local;

II - suplementar a legislação federal e a estadual no que couber; $[\ldots]^{196}$

Assim, é possível que as leis estaduais e distrital citadas sejam consideradas constitucionais, caso venham a ter sua constitucionalidade verificada pelo Poder Judiciário. No caso das quatro leis municipais citadas há um evidente conflito de competência legislativa, pois nos seus respectivos Estados já há leis que tratam dos direitos dos usuários dos serviços de saúde. Nesses casos deve prevalecer a competência legislativa dos Estados sobre os Municípios.

A diversidade de leis locais é decorrente da ausência de uma lei federal a respeito dos direitos dos usuários dos serviços de saúde e da limitação de suporte

\footnotetext{
194 MARQUES, José Frederico. Tratado de direito penal. 1. ed. atual. Campinas: Bookseller, 1997, volume 2, p. 177.

195 BRASIL, Ministério da Saúde. Portaria oㅡ 675, de 30/03/2006, do Gabinete do Ministro da Saúde, publicada no D.O.U. de 31/03/2006.
} 
de vida. A superveniência de uma lei federal daria fim a essa diversidade regional (art. 24, §4, CF), além de maior clareza sobre esses assuntos.

\subsection{0 costume e a jurisprudência}

Há doutrinadores que admitem o costume como norma justificadora da conduta. Assim, a prática costumeira pode não ser tida como crime, excluída a ilicitude pelo exercício regular do direito ${ }^{197}$. Há casos de costumes contrários às disposições da lei (contra legem) acabam por se impor na prática judiciária ${ }^{198}$.

A limitação de suporte de vida em pacientes terminais vem sendo praticada no Brasil de forma costumeira, reiterada. A execução de medidas de limitação de suporte de vida em hospitais brasileiros tem sido reconhecida por médicos na imprensa leiga e na literatura médica (artigos citados no primeiro capítulo), mas não se tem notícia de processos criminais por essa prática ${ }^{199}$. A ausência de denúncias de casos de limitação de suporte de vida permite cogitar que talvez a sociedade brasileira venha admitindo sua prática regular. Porém, resta a incerteza se a limitação de suporte de vida seria admitida como conduta não criminosa (atípica ou lícita) se a questão fosse apresentada à Justiça.

Nessa época de crescente judicialização das relações sociais e da política ${ }^{200}$ é surpreendente que o tema das decisões de final de vida permaneça sem uma orientação jurisprudencial. Apesar de suspensa, a Resolução CFM nำ1.805 tem o

\footnotetext{
${ }^{196}$ BRASIL, Constituição da República Federativa do Brasil, de 05/10/1988. Publicada no D.O.U. de 05/10/1988.

197 MARQUES, José Frederico. Tratado de direito penal. 1. ed. atual. Campinas: Bookseller, 1997, volume 2, p. 177-180.

GRECO, Rogério. Curso de direito penal: parte geral. 7. ed. Niterói: Impetus, 2006, volume 1, p. 401. NORONHA, Edgard Magalhães. Direito penal. 12. ed. São Paulo: Saraiva, 1973, volume 1, p. 196.

CAPEZ, Fernando. Curso de direito penal: parte geral. 4. ed. rev. e atual. São Paulo: Saraiva, 2002, volume 1, p. 260-261.

${ }^{198}$ FERRAZ Junior, Tercio Sampaio. Introdução ao estudo do direito: técnica, decisão, dominação. 4. ed. São Paulo: Atlas, 2003, p. 243.

${ }^{199}$ SOARES, Márcio; TERZI, Renato G.G.; PIVA, Jefferson P. End-of-life care in Brazil. Intensive Care Medicine 2007, volume 33, p. 1014-1017.

200 VIANNA, Luiz Werneck; CARVALHO, Maria Alice Resende de; MELO, Manuel Palacios Cunha; BURGOS, Marcelo Baumann. A judicialização da política e das relações sociais no Brasil. Rio de Janeiro: Revan, 1999, 272 p.
} 
mérito de ter provocado o Poder Judiciário a se manifestar a respeito da limitação de suporte de vida no Brasil, mediante pedido do Ministério Público Federal ${ }^{201}$.

201 OLIVEIRA, Wellington Divino Marques de. Petição inicial da ação civil pública no 2007.34.00.014809-3, da 14 ${ }^{\text {a }}$ Vara Federal, da Seção Judiciária do Distrito Federal. Brasília: Ministério Público Federal, 2007, p. 114. Disponível em: <http://noticias.pgr.mpf.gov.br/noticias-dosite/pdfs/ACP\%20Ortotanasia.pdf> Data da consulta: 03/06/2009. 


\section{CONCLUSÃO}

O direito brasileiro adota tradicionalmente uma postura paternalista para a proteção do direito à vida, permitindo a administração de tratamentos médicos mesmo contra a vontade do paciente em caso de iminente perigo de vida.

Por outro lado, também é comum o paternalismo médico ao se adotar a limitação do suporte de vida sem que sejam consultados o paciente ou seus familiares. A limitação de suporte de vida em pacientes terminais vem sendo praticada no Brasil de forma costumeira, reiterada. A execução de medidas de limitação de suporte de vida em hospitais brasileiros tem sido reconhecida por médicos na imprensa leiga e na literatura médica. Mesmo assim o assunto continua sendo tratado como tabu pelo receio de punição.

A doutrina tradicional caracteriza o direito à vida como um bem jurídico indisponível e irrenunciável. Porém, essas características não são absolutas, pois são aceitas condutas de livre exposição a riscos de vida, como ocorre nas cirurgias estéticas e nos esportes perigosos (violentos, motorizados, radicais).

A princípio a prática da eutanásia configura o crime de homicídio privilegiado. Há doutrinadores que entendem que o médico tem o dever de intervir tentando salvar a vida mesmo contra a vontade do paciente terminal. No entanto, não se tem notícia de qualquer denúncia nesse sentido.

Os tratamentos paliativos vem sendo praticados no Brasil livremente. A autonomia da vontade do paciente para receber o tratamento paliativo é fundamental, mas a decisão deve ser compartilhada com o médico. O direito de aceitar ou recusar tratamentos não corresponde a um direito de se exigir quaisquer tratamentos

A analgesia paliativa está relacionada ao duplo efeito, o alívio da dor com dosagens elevadas de opióides acarreta risco de morte por parada respiratória. Cabe ao paciente decidir se quer assumir esse risco. A princípio trata-se de um risco permitido, pois se qualquer um pode assumir o risco de vida decorrente de uma 
cirurgia estética ou da prática de um esporte perigoso, seguindo uma motivação hedonista, mais razão tem o paciente terminal em assumir o risco de vida decorrente do tratamento recomendado para aliviar sua dor.

Normas mais recentes vêm mitigando o tradicional paternalismo ao valorizarem a autonomia da vontade dos usuários dos serviços de saúde. Porém, o legislador federal ainda não se manifestou a respeito do assunto. Essa falta de uma orientação central abriu espaço para a criação de leis locais e de normas infralegais, cuja legitimidade e eficácia são questionadas.

Há insegurança jurídica a respeito do direito dos pacientes terminais tomarem decisões de final de vida, especialmente quanto à limitação de suporte de vida. A literatura que trata das decisões de fim de vida é confusa e carece de consenso. Não há orientação jurisprudencial sobre o assunto ainda. 


\section{REFERÊNCIAS}

AMARAL, Francisco. Direito civil: introdução. 7. ed. rev., atual. e aum. Rio de Janeiro: Renovar, 2008, p. 284.

AMERICAN ACADEMY OF ORTHOPAEDIC SURGEONS. Socorros médicos de emergência. Tradução de Lís Araújo Zin. Fortaleza: Secretaria de Saúde do Estado do Ceará, 1988, 358 p.

ARIÈS, Philippe. História da morte no ocidente. Tradução de Priscila Viana de Siqueira. Rio de Janeiro: Ediouro, 2003, 312 p.

ASSEMBLÉIA LEGISLATIVA DO ESTADO DE MINAS GERAIS, Emendas ao Projeto de Lei no 2/2003. Disponível em: <http://hera.almg.gov.br/cgi-bin/nphbrs?d=MATE\&co1=e\&p=1\&u=http://www.almg.gov.br/mate/chama_pesquisa.asp\&S ECT1=IMAGE\&SECT2=THESOFF\&SECT3=PLUROFF\&SECT6=BLANK\&SECT7=LI NKON\&l=20\& $r=1 \& f=L 3 ; 1 ;(P L .200300002061$ [codi])[txmt];all;mate\&s1=LEl+adj+1627 $9+$ adj+2006.norm.\&s2=remissivo\&SECT8=TODAPROP $>$ Data da consulta: 26/05/2009.

ASSEMBLÉIA LEGISLATIVA DO ESTADO DE MINAS GERAIS, Projeto de Lei no 2/2003. Disponível em: <http://hera.almg.gov.br/cgi-bin/nphbrs?d=MATE\&co1=e\&p=1\&u=http://www.almg.gov.br/mate/chama_pesquisa.asp\&S ECT1 $=$ IMAGE\&SECT2=THESOFF\&SECT3=PLUROFF\&SECT6=BLANK\&SECT7=LI NKON\&I=20\& $r=1 \& f=L 3 ; 1 ;(P L .20030000201$ [codi]) [txmt];all;mate\&s1=LEI+adj+16279 +adj+2006.norm.\&s2=remissivo\&SECT8=TODAPROP > Data da consulta: 26/05/2009.

BARROSO, Luís Roberto. Constitucionalista diz que lei ampara ortotanásia no país. Folha de São Paulo 04/12/2006. p. C4. apud BITTENCOURT, José. Projeto de Lei no 264/2007, da Assembléia Legislativa do Estado de São Paulo. Acrescenta parágrafo ao artigo $2^{\circ}$ da Lei ํㅜ 10.241, de 17 de março de 1999, que dispõe sobre os direitos dos usuários dos servidores e das ações de saúde no Estado e dá outras providências. Disponível em: $<$ http://webspl1.al.sp.gov.br/internet/download?poFilelfs=9071722\&/propositura_Proj etodelei_705709.doc"> Data da consulta: 01/06/2009.

BENET, Leslie Z. Introdução. In: HARDMAN, Joel G; LIMBIRD, Lee E (editoreschefes); MOLINOFF, Perry B.; RUDDON, Raymond W. (editores); GILMAN, Alfred Goodman (editor-consultor). Goodman \& Gilman: as bases farmacológicas da 
terapêutica. 9. ed. Supervisão da tradução de Penildon Silva. Rio de Janeiro: McGraw-Hill, 1996, p. 1-2.

BILLINGS, J. Andrew. O cuidado a pacientes terminais e às suas famílias. In: GOLDMAN, Lee; AUSIELLO, Dennis (editores). Cecil, tratado de medicina interna. Tradução da 22. ed. Tradução de Maria Angelica Borges dos Santos. Rio de Janeiro: Elsevier, 2005, volume 1, p. 11-16.

BITENCOURT, Almir Galvão Vieira; DANTAS, Maira Pereira; NEVES, Flávia Branco Cerqueira Serra; ALMEIDA, Alessandro de Moura; MELO, Rodrigo Morel Vieira de; ALBUQUERQUE, Ligia Carvalho; GODINHO, Tiana Mascarenhas; AGARENO, Sydney; TELES, José Mário M.; FARIAS, Augusto M.C.; MESSEDER, Otavio H. Condutas de limitação terapêutica em pacientes internados em unidade de terapia intensiva. Revista Brasileira de Terapia Intensiva 2007, volume 19(2), p. 137-143.

BITENCOURT, Cezar Roberto. Tratado de direito penal: parte especial. 8. ed. rev. e atual. São Paulo: Saraiva, 2008, volume 2, 466 p.

BRANCO, Paulo Gustavo Gonet. Direitos fundamentais: tópicos de teoria geral. In: MENDES, Gilmar Ferreira; COELHO, Inocêncio Mártires; BRANCO, Paulo Gustavo Gonet. Curso de direito constitucional. 4. ed. rev. e atual. São Paulo: Saraiva, 2009, p. 265-327.

BRANCO, Paulo Gustavo Gonet. Direito à vida. In: MENDES, Gilmar Ferreira; COELHO, Inocêncio Mártires; BRANCO, Paulo Gustavo Gonet. Curso de direito constitucional. 4. ed. rev. e atual. São Paulo: Saraiva, 2009, p. 393-401.

BRASIL, Decreto-Lei no 1001, Código Penal Militar, de 21/10/1969. Publicado no D.O.U. de 21/10/1969.

BRASIL, Exposição de Motivos do Decreto-Lei no 2.848, de 7 de Dezembro de 1940. In: MIRABETE, Julio Fabbrini. Código Penal interpretado. 5. ed. Atualizada por Renato N. Fabbrini. São Paulo: Atlas, 2005, p. 63.

BRASIL, Constituição da República Federativa do Brasil, de 05/10/1988. Publicada no D.O.U. de 05/10/1988.

BRASIL. Decisão interlocutória proferida na ação civil pública nº 2007.34.00.0148093, Brasília: 14 Vara Federal, da Seção Judiciária do Distrito Federal, 30/05/2008. Disponível em: <http://processual-df.trf1.gov.br/Processos/ProcessosSecaoOra/Cons ProcSecaoPub.php?SECAO=DF \&proc $=200734000148093 \& \mathrm{sec}=3400 \& \mathrm{var}=14 \& \mathrm{dtp}=$ 30/05/2008\&mat=393\&tpb=2\&seq=13> Data da consulta: 03/06/2009. 
BRASIL, Decreto-Lei no 2.848, de 07/12/1940. Código Penal. Publicado no D.O.U. de $31 / 12 / 1940$ e retificado no D.O.U. de 03/01/1941.

BRASIL, Lei no 8.080, de 19/09/1990. Dispõe sobre as condições para a promoção, proteção e recuperação da saúde, a organização e o funcionamento dos serviços correspondentes e dá outras providências. Publicada no D.O.U. de 20/09/1990.

BRASIL, Lei no 9.263, de 12/01/1996. Regula o $§ 7^{0}$ do art. 226 da Constituição Federal, que trata do planejamento familiar, estabelece penalidades e dá outras providências. Publicada no D.O.U. de 15/01/1996.

BRASIL, Lei no 9.434, de 04/02/1997. Dispõe sobre a remoção de órgãos, tecidos e partes do corpo humano para fins de transplante e tratamento e dá outras providências. Publicada no D.O.U. de 05/02/1997.

BRASIL, Lei no 10.406, de 10/01/2002. Código Civil. Publicado no D.O.U. de $11 / 01 / 2002$.

BRASIL, Ministério da Saúde. Carta dos Direitos dos Usuários da Saúde. Aprovada pela Portaria n 675, de 30/03/2006, do Gabinete do Ministro da Saúde, publicada no D.O.U. de $31 / 03 / 2006$.

BRASIL, Ministério da Saúde. Portaria no 675, de 30/03/2006, do Gabinete do Ministro da Saúde, publicada no D.O.U. de 31/03/2006.

BRASIL. Ministério da Saúde. Secretaria de Atenção à Saúde. Departamento de Ações Programáticas Estratégicas. Área Técnica de Saúde da Mulher. Prevenção e Tratamento dos Agravos Resultantes da Violência Sexual contra Mulheres e Adolescentes: norma técnica. 2. ed. atual. e ampl. Brasília: Ministério da Saúde, 2005, p. 45-46. Disponível em:

<http://portal.saude.gov.br/portal/arquivos/pdf/norma_prevencao_atualizada.pdf> Data da consulta 03/06/2009.

BRITO, António José dos Santos Lopes de; RIJO, José Manuel Subtil Lopes. Estudo jurídico da eutanásia em Portugal: direito sobre a vida ou dever de viver? Coimbra: Almedina, 2000, $251 \mathrm{p}$.

CÂMARA MUNICIPAL DE JUIZ DE FORA, Lei nํ 11.642, de 22/07/2008. Dispõe sobre os direitos do usuário dos serviços e das ações de Saúde, no Município de Juiz de Fora. Disponível em: <http://isal.camarajf.mg.gov.br/scripts/salpxnjur.dll/njn?njt=LEI\&njn=11642\&njc=> Data da consulta: 26/05/2009. 
CÂMARA MUNICIPAL DE JUIZ DE FORA, Razão de Veto ao Projeto de Lei no 7/2008. Disponível em:

$<$ http://isal.camarajf.mg.gov.br/scripts/salpx.dll/plti?pla=2008\&plt=PLEl\&pln=000007 \&pls=16\&pld=\%20-\%20Projeto\%20de\%20Lei\&plp=5212-00/2006> Data da consulta: 26/05/2009.

CAPEZ, Fernando. Curso de direito penal: parte geral. 4. ed. rev. e atual. São Paulo: Saraiva, 2002, volume 1, 538p.

CAPEZ, Fernando. Curso de direito penal: parte especial. São Paulo: Saraiva, 2004, volume 2, $612 \mathrm{p}$.

COLLUCCI, Cláudia; LEITE, Fabiane; GOIS, Antônio. Médicos revelam que eutanásia é prática habitual em UTIs do país. Folha de São Paulo. 20/02/2005. Disponível em: <http://www1.folha.uol.com.br/folha/cotidiano/ult95u105876.shtml> Data da consulta: 04/05/2009.

CONSELHO FEDERAL DE MEDICINA, Resolução no 1634, de 11/04/2002, publicada no D.O.U. de 29/04/2002.

CONSELHO FEDERAL DE MEDICINA, Resolução no 1805, de 09/11/2006, publicada no D.O.U. de 28/11/2006.

COSTA Junior, Paulo José. Comentários ao código penal. 4. ed. reform. e atual. São Paulo: Saraiva, 1996, p.

COVERDALE, John H.; MCCULLOUGH, Laurence B.; CHERVENAK, Frank A. The ethics of randomized placebo-controlled trials of antidepressants with pregnant women: a systematic review. Obstetrics \& Gynecology 2008, volume 112(6), p. 1361-1368.

CUCHERAT, M.;HAUGH, M.C.; GOOCH, M.; BOISSEL, J.P. Evidence of clinical efficacy of homeopathy. A meta-analysis of clinical trials. HMRAG. Homeopathic Medicines Research Advisory Group. European Journal of Clinical Pharmacology 2000, volume 56(1), p. 27-33.

DELMANTO, Celso; DELMANTO, Roberto; DELMANTO Junior, Roberto; DELMANTO, Fabio M. de Almeida. Código penal comentado. 7. ed. rev. atual. e ampl. Rio de Janeiro: Renovar, 2007, volume 1, p. 369. 
DERRY, C.J.; DERRY, S.; MCQUAY, H.J.; MOORE, R.A. Systematic review of systematic reviews of acupuncture published 1996-2005. Clinical Medicine 2006, volume 6(4), p. 381-386.

DISTRITO FEDERAL, Lei oㅡ 2.804, de 25/10/2001, do Distrito Federal. Dispõe sobre os direitos dos usuários dos serviços e das ações de saúde no Distrito Federal. Publicada no D.O.D.F. de 07/11/2001. Disponível em: $<$ http://www.cl.df.gov.br/Legislacao/buscarLei-2181!buscarLei.action> Data da consulta: 25/05/2009.

DONEDA, Danilo. Os direitos da personalidade do novo Código Civil (arts. 11 a 21). In: TEPEDINO, Gustavo (coordenador). A parte geral do novo Código Civil: estudos na perspectiva civil-constitucional. 3. ed. rev. Rio de Janeiro: Renovar, 2007, p. 3560.

DRANE, James F. El cuidado del enfermo terminal. Ética clínica y recomendaciones prácticas paras instituciones de salud y servicios de cuidados domiciliarios. Washington: Organização Panamericana da Saúde, 1999, 172 p.

EMANUEL, Ezekiel J. Bioética na prática médica In: GOLDMAN, Lee; AUSIELLO, Dennis (editores). Cecil, tratado de medicina interna. Tradução da 22. ed. Tradução de Maria Angelica Borges dos Santos. Rio de Janeiro: Elsevier, 2005, volume 1, p. $5-11$.

ERNST, E. A systematic review of systematic reviews of homeopathy. British Journal of Clinical Pharmacology 2002, volume 54(6), volume 577-582.

ESTADO DE MINAS GERAIS, 2ª̂amara Criminal do Tribunal de Justiça de Minas Gerais, Apelação 20.217, relator Desembargador Aníbal Pacheco, 01/10/1987, Revista dos Tribunais, volume 628, p. 352.

ESTADO DE MINAS GERAIS, $2^{2}$ Câmara Criminal do Tribunal de Justiça de Minas Gerais, Apelação 39.268-8, relator Desembargador Guido de Andrade, 01/06/1995, DJ 25/06/1996, Revista dos Tribunais, volume 736, p. 676.

ESTADO DE PERNAMBUCO, Lei oㅜ 12.770, de 08/03/2005, do Estado de Pernambuco. Dispõe sobre os direitos dos usuários dos serviços e das ações de saúde no Estado e dá outras providências. Disponível em: $<$ http://legis.alepe.pe.gov.br/legis_inferior_norma.aspx?cod=LE12770> Data da consulta: 25/05/2009.

ESTADO DE RORAIMA, Lei no 687, de 17/10/2008, do Estado de Roraima. Dispõe sobre a cartilha dos Direitos do paciente. Disponível em: 
<http://www.al.rr.gov.br/publico/setores/000/2/download/Leis\%202008/Lei\%20no\%20 687\%20de\%2017.10.08.pdf> Data da consulta: 28/06/2009.

ESTADO DE SÃO PAULO, Lei oㅜ 10.241, de 17/03/1999, do Estado de São Paulo. Dispõe sobre os direitos dos usuários dos serviços e das ações de saúde no Estado e dá outras providências. Disponível em:

<http://www.al.sp.gov.br/repositorio/legislacao/lei/1999/lei\%20n.10.241,\%20de\%201

7.03.1999.htm> Data da consulta: 25/05/2009.

ESTADO DO MATO GROSSO, Lei Complementar no 283, de 09/10/2007, do Estado do Mato Grosso. Modifica o inciso IV e acrescenta Parágrafo único ao Art. 4º da Lei Complementar ํㅡ 22, de 09 de novembro de 1992. Disponível em:

<http://www.al.mt.gov.br/v2008/Raiz\%20Estrutura/Leis/admin/ssl/ViewPrincipal2.asp ?page=Ic283.htm > Data da consulta: 25/05/2009.

ESTADO DO RIO DE JANEIRO, Lei no 3.613, de 25/10/2001, do Estado do Rio de Janeiro. Dispõe sobre os direitos dos usuários dos serviços e das ações de saúde no Estado do Rio de Janeiro e dá outras providências. Disponível em: <http://alerjln1.alerj.rj.gov.br/CONTLEI.NSF/b24a2da5a077847c032564f4005d4bf2/1 ad0f379285f3c0503256a9a0050a557?OpenDocument> Data da consulta: 25/05/2009.

FAKHRY, Samir M.; FATA, Paola. How low is too low? Cardiac risks with anemia. Critical Care 2004, volume 8(Suppl 2), p. S11-S14.

FERRAZ Junior, Tercio Sampaio. Introdução ao estudo do direito: técnica, decisão, dominação. 4. ed. São Paulo: Atlas, 2003, 370 p.

FRANCO, Alberto Silva; STOCO, Rui (coordenadores). Código Penal e sua interpretação jurisprudencial: parte especial. 7. ed. rev., atual. e ampl. São Paulo: Editora Revista dos Tribunais, 2001, volume 2, 4300 p.

GOMES, Luiz Flávio (coordenador); MOLINA, Antonio García-Pablos de. Direito penal: parte geral. São Paulo: Editora Revista dos Tribunais, 2007, volume 2, 942 p.

GRECO, Rogério. Curso de direito penal: parte geral. 7. ed. Rio de Janeiro: Impetus, 2006, volume 1, $823 \mathrm{p}$.

GRECO, Rogério. Curso de direito penal: parte especial. 3. ed. Niterói: Impetus, 2007, volume 2, $628 \mathrm{p}$. 
HEALY, D. Ethics and science of placebo-controlled trials. Journal of Psychopharmacology 2008, volume 22(6), p. 598-599.

HEBERT, Paul C.; WELLS, George; BLAJCHMAN, Morris A.; MARSHALL, John; MARTIN, Claudio; PAGLIARELLO, Giuseppe; TWEEDDALE, Martin; SCHWEITZER, Irwin; YETISIR, Elizabeth; The Transfusion Requeriments in Critical Care Investigators for the Canadian Critical Care Trials Group. A multicenter, randomized, controlled clinical trial of transfusion requirements in critical care. New England Journal of Medicine 1999, volume 340(6), p. 409-417.

HUNGRIA, Nelson. Comentários ao código penal. 4. ed. Rio de Janeiro: Forense, 1958, volume 1, tomo 2, $546 \mathrm{p}$.

HUNGRIA, Nelson. Comentários ao código penal. 4. ed. Rio de Janeiro: Forense, 1958, volume 4, p. 418.

HUNGRIA, Nelson. Comentários ao código penal. 4. ed. Rio de Janeiro: Forense, 1958 , volume $5,532 \mathrm{p}$.

ISSA, Luciana Jardim; REIS, Amélia Gorete. Suporte avançado de vida na criança. In: NOBRE, Fernando; SERRANO Jr., Carlos V. (editores) Tratado de cardiologia SOCESP. Barueri/SP: Manole, 2005, p. 1606-1613.

IWASSO, Simone. Nas UTIs, 30\% dos pacientes são terminais. O Estado de São Paulo 29/07/2006. Disponível em:

<http://www.estado.com.br/editorias/2006/07/29/ger-1.93.7.20060729.4.1.xml> Data da consulta: 24/04/2009.

JESUS, Damásio E. de. Direito penal: parte especial. São Paulo: Saraiva, 1999, volume 2, p. 102-103 apud FRANCO, Alberto Silva; STOCO, Rui (coordenadores). Código Penal e sua interpretação jurisprudencial: parte especial. 7. ed. rev., atual. e ampl. São Paulo: Editora Revista dos Tribunais, 2001, volume 2, p. 2215.

KIPPER, D.J.; PIVA, J.P.; GARCIA, P.C.; EINLOFT, P.R.; BRUNO, F.; LAGO, P. et al. Evolution of the medical practices and mode of death on pediatric intensive care units in Southern Brazil. Pediatric Critical Care Medicine 2005 volume 6. p. 258-263. apud LAGO, Patrícia Miranda; GARROS, Daniel; PIVA, Jefferson P. Participação da família no processo decisório de limitação de suporte de vida: paternalismo, beneficência e omissão. Revista Brasileira de Terapia Intensiva 2007, volume 19(3), p. 364-368.

KLAASSEEN, Curtis D. Princípios de toxicologia e tratamento do envenenamento. In: HARDMAN, Joel G; LIMBIRD, Lee E (editores-chefes); MOLINOFF, Perry B.; 
RUDDON, Raymond W. (editores); GILMAN, Alfred Goodman (editor-consultor). Goodman \& Gilman: as bases farmacológicas da terapêutica. 9. ed. Supervisão da tradução de Penildon Silva. Rio de Janeiro: McGraw-Hill, 1996, p. 45-54.

KLEIJNER, Jos; KNIPSCHILD, Paul; TER RIET, Gerben. Clinical trials of homoeopathy. British Medical Journal 1991, volume 302(6772), p. 316-23.

LAGO, Patrícia M.; PIVA, Jefferson; KIPPER, Délio; GARCIA, Pedro Celiny; PRETTO, Cristiane; GIONGO, Mateus; BRANCO, Ricardo; BUENO, Fernanda; TRAIBER, Cristiane; ARAÚJO, Taisa; WORTMANN, Daniela; LIBRELATO, Graziela; SOARDI, Deise. Life support limitation at three pediatric intensive care units in southern Brazil. Jornal de Pediatria 2005, volume 81(2). p. 111-117.

LAGO, Patrícia M.; DEVICTOR, Denis; PIVA, Jefferson; BERGOUNIOUX, Jean. End-of-life care in children: the Brazilian and the international perspectives. Jornal de Pediatria 2007, volume 83(2-Supl.), p. S109-S116.

LAGO, Patrícia Miranda; GARROS, Daniel; PIVA, Jefferson P. Terminalidade e condutas de final de vida em unidades de terapia intensiva pediátrica. Revista Brasileira de Terapia Intensiva 2007, volume 19(3), p. 359-363.

LEPARGNEUR, Hubert. Reflexões acerca da eutanásia. In: BARCHIFONTAINE, Christian de Paul de; PESSINI, Leo (organizadores). Bioética: alguns desafios. São Paulo: Loyola, 2001, 347 p.

LINDE, Klaus; MELCHART, Dieter. Randomized controlled trials of individualized homeopathy: a state-of-the-art review. The Journal of Alternative and Complementary Medicine 1998, volume 4(4), p. 371-388.

LIONE, Armand. Ethics of placebo use in clinical care. Lancet 2003, volume 362, p. 999.

SILVA, Jóse Afonso da. Curso de direito constitucional positivo. 28. ed. rev. e atual. São Paulo: Malheiros, 2007, 928 p.

MARQUES, Flávio Rocha Brito; TIMERMAN, Sergio; FERREIRA, Dario Fortes; QÜILICI, Ana Paula; GONÇALEZ, Maria Margarita Castro; RAMIRES, José Antônio Franchini. Suporte básico de vida no adulto. In: NOBRE, Fernando; SERRANO Jr., Carlos V. (editores) Tratado de cardiologia SOCESP. Barueri/SP: Manole, 2005, p. 1586-1596. 
MARQUES, José Frederico. Tratado de direito penal. 1. ed. atual. Campinas: Bookseller, 1997, volume 2, p. 490.

MIRABETE, Julio Fabbrini. Código Penal interpretado. 5. ed. Atualizada por Renato N. Fabbrini. São Paulo: Atlas, 2005, 2700 p.

MIRABETE, Julio Fabbrini. Manual de direito penal: parte especial (arts. 121 a 234 do CP). 24. ed. Revista e atualizada por Renato N. Fabbrini. São Paulo: Atlas, 2006, volume 2, $510 \mathrm{p}$.

MIRABETE, Julio Fabbrini. Manual de direito penal: parte geral (arts. 1ํa 120 do $C P$ ). 23. ed. Revista e atualizada por Renato N. Fabbrini. São Paulo: Atlas, 2006, volume $1,483 \mathrm{p}$.

MORETTI, Miguel Antonio. Suporte avançado de vida no adulto. In: NOBRE, Fernando; SERRANO Jr., Carlos V. (editores) Tratado de cardiologia SOCESP. Barueri/SP: Manole, 2005, p. 1597-1605.

MUNICÍPIO DE BELO HORIZONTE, Lei no 8.926, de 02/08/2004, do Município de Belo Horizonte. Dispõe sobre os direitos do usuário dos serviços e das ações de Saúde, no Município. Texto no arquivo "lei8926-cons.doc", disponível a partir de: $<$ tttp://www.cmbh.mg.gov.br/index.php?option=com_wrapper\&ltemid=580> Data da consulta: 25/05/2009.

MUNICÍPIO DE MARÍLIA, Lei oㅜ5.280, de 13/09/2002, do Município de Marília. Dispõe sobre os direitos dos usuários dos serviços e as ações de saúde no Município e dá outras providências. Texto no arquivo "Arquivo-_5280.pdf", disponível a partir de:

$<$ http://www.camar.sp.gov.br/novo/index2.php?pag=leisano\&ano=2002\&idtipolei=1\& pg=11> Data da consulta: 26/05/2009.

MUNICÍPIO DE SÃO PAULO, Lei no 14.413, de 31/05/2007, do Município de São Paulo. Dispõe sobre os direitos dos usuários dos serviços e das ações de saúde no Município e dá outras providências. Pesquisa do texto da lei disponível a partir de: $<$ http://www3.prefeitura.sp.gov.br/cadlem/secretarias/negocios_juridicos/cadlem/pes qnumero.asp?> Data da consulta: 25/05/2009.

NIES, Alan S.; SPIELBERG, Stephen P. Princípios da Terapêutica. In: HARDMAN, Joel G; LIMBIRD, Lee E (editores-chefes); MOLINOFF, Perry B.; RUDDON, Raymond W. (editores); GILMAN, Alfred Goodman (editor-consultor). Goodman \& Gilman: as bases farmacológicas da terapêutica. 9. ed. Supervisão da tradução de Penildon Silva. Rio de Janeiro: McGraw-Hill, 1996, p. 31-44. 
NORONHA, Edgard Magalhães. Direito penal. 12. ed. São Paulo: Saraiva, 1973, volume 1, $429 \mathrm{p}$.

NORONHA, Edgard Magalhães. Direito penal. 12. ed. São Paulo: Saraiva, 1976, volume 2, $571 \mathrm{p}$.

NUCCI, Guilherme de Souza. Manual de direito penal: parte geral: parte especial. São Paulo: Editora Revista dos Tribunais, 2006, 1056 p.

OLIVEIRA, Wellington Divino Marques de. Petição inicial da ação civil pública no 2007.34.00.014809-3, da 14 aㅡ Vara Federal, da Seção Judiciária do Distrito Federal. Brasília: Ministério Público Federal, 2007, p. 114. Disponível em:

$<$ http://noticias.pgr.mpf.gov.br/noticias-do-site/pdfs/ACP\%200rtotanasia.pdf> Data da consulta: 03/06/2009.

ORGANIZAÇÃO MUNDIAL DA SAÚDE. Alívio da dor no câncer. Brasília: Ministério da Saúde, 1991, 82 p.

ORGANIZAÇÃO MUNDIAL DA SAÚDE. Alivio de los síntomas en el enfermo terminal. Genebra: Organização Mundial da Saúde, 1999, 118 p.

ORGANIZAÇÃO MUNDIAL DA SAÚDE. Alivio del dolor y tratamiento paliativo en el cáncer infantil. Genebra: Organização Mundial da Saúde, 1999, 85 p.

OTHERO, Jairo Constante Bitencourt. Atitudes médicas nas últimas 48 horas de vida de pacientes adultos internados em três unidades de tratamento intensivo no sul do Brasil. Dissertação de mestrado. Orientador Jefferson Pedro Piva. Porto Alegre: Pontifícia Universidade Católica do Rio Grande do Sul, 2008, 100 p. Disponível em: <http://tede.pucrs.br/tde_busca/arquivo.php?codArquivo=1444> Data da consulta: 05/06/2009.

PESSINI, Leo. Como lidar com o paciente em fase terminal. 5. ed. rev. e atual. Aparecida: Editora Santuário, 1990, 157 p.

PIERANGELI, José Henrique. Manual de direito penal brasileiro: parte especial (arts. 121 a 234). São Paulo: Editora Revista dos Tribunais, 2005, 912 p.

PRADO, Luiz Regis. Curso de direito penal brasileiro: parte geral - arts. 1ㅇ a 120. 7. ed. rev. atual. e ampl. São Paulo: Editora Revista dos Tribunais, 2007, volume 1, 796 p. 
PRADO, Luiz Regis. Curso de direito penal brasileiro: parte especial - arts. 121 a 249. 7. ed. rev. atual. e ampl. São Paulo: Editora Revista dos Tribunais, 2008, volume 2, $800 \mathrm{p}$.

REISINI, Terry; PASTERNAK, Gavril. Analgésicos e antagonistas opióides. In: HARDMAN, Joel G; LIMBIRD, Lee E (editores-chefes); MOLINOFF, Perry B.; RUDDON, Raymond W. (editores); GILMAN, Alfred Goodman (editor-consultor). Goodman \& Gilman: as bases farmacológicas da terapêutica. 9. ed. Supervisão da tradução de Penildon Silva. Rio de Janeiro: McGraw-Hill, 1996, p. 379-404.

RIBEIRO, Diaulas Costa. Autonomia: viver a própria vida e morrer a própria morte. Cadernos de Saúde Pública, Rio de Janeiro, 2006, volume 22(8), p. 1749-1754.

RIBEIRO, Diaulas Costa . Eutanásia, suicídio assitido, distanásia e suspensão de esforço terapêutico. Revista Jurídica Consulex, Brasília, 2005, volume 199, p. 34-35.

SÁ, Maria de Fátima Freire de. Direito de morrer: eutanásia, suicídio assistido. 2. ed. Belo Horizonte: Del Rey, 2005, 184 p.

SCHELP, Diogo. Até onde prolongar a vida: Como médicos e familiares decidem se devem ou não suspender os chamados tratamentos fúteis, que apenas mantêm vivos doentes para os quais não há esperança de cura. Veja 04/09/2002. Disponível em: <http://veja.abril.com.br/040902/p_082.html> Data da consulta: 24/04/2009.

SHANG, Aijing; HUWILER-MÜNTENER, Karin; NARTEY, Linda; JÜNI, Peter; DÖRIG, Stephan; STERNE, Jonathan A.C.; PEWSNER, Daniel; EGGER, Matthias. Are the clinical effects of homoeopathy placebo effects? Comparative study of placebo-controlled trials of homoeopathy and allopathy. Lancet 2005, volume 366(9487), p. 726-732.

SILVA, Jóse Afonso da. Curso de direito constitucional positivo. 28. ed. rev. e atual. São Paulo: Malheiros, 2007, 928 p.

SOARES, André Marcelo M.; PINHO, João Carlos de. Questões bioéticas relativas ao final da vida. In: MOSER, Antônio; SOARES, André Marcelo M. Bioética: do consenso ao bom senso. Petrópolis: Vozes, 2006, 190 p.

SOARES, Márcio; TERZI, Renato G.G.; PIVA, Jefferson P. End-of-life care in Brazil. Intensive Care Medicine 2007, volume 33, p. 1014-1017. 
SOARES, Márcio; TERZI, Renato G.G.; PIVA, Jefferson P. Série temática Terminalidade da vida e cuidados de final de vida na unidade de terapia intensiva. Revista Brasileira de Terapia Intensiva 2007, volume 19(3), p. 357-358.

TEODORO, Plínio. Lei criada por Mário Covas permite ortotanásia em São Paulo desde 1999. O Globo 10/11/2006. Disponível em:

<http://oglobo.globo.com/pais/mat/2006/11/10/286601451.asp> Data da consulta: 08/06/2009.

TEPEDINO, Gustavo (coordenador). A parte geral do novo Código Civil: estudos na perspectiva civil-constitucional. 3. ed. rev. Rio de Janeiro: Renovar, 2007, 501 p.

TERZI, Renato; ARAÚJO, Sebastião. Técnicas básicas em U.T.I. São Paulo: Manole, 1992, $444 \mathrm{p}$.

TORREÃO, Lara A.; REIS, Amélia G.A.C.; TROSTER, Eduardo J.; OSELKA, Gabriel. Cardiopulmonary resuscitation: discrepancy between the actual cardiopulmonary resuscitation and the documentation in the medical record. Jornal de Pediatria 2000, volume 76(6), p. 429-433.

VENOSA, Sílvio de Salvo. Direito civil: parte geral. 4. ed. São Paulo: Atlas, 2004, volume 1, p. 147-149.

VIANNA, Luiz Fernando. Doentes crônicos recebem cuidados paliativos em 40 hospitais. Folha de São Paulo, 03/05/2009. Disponível em:

<http://www1.folha.uol.com.br/folha/ciencia/ult306u559848.shtml> Data da consulta: 19/05/2009.

VIANNA, Luiz Werneck; CARVALHO, Maria Alice Resende de; MELO, Manuel Palacios Cunha; BURGOS, Marcelo Baumann. A judicialização da política e das relações sociais no Brasil. Rio de Janeiro: Revan, 1999, 272 p.

YAGUCHI, Arino; TRUOG, Robert D.; CURTIS, Randall; LUCE, John M.; LEVY, Mitchell M.; MELOT, Christian; VINCENT, Jean-Louis. International differences in end-of-life attitudes in the intensive care unit. Archives of Internal Medicine 2005, volume 165, p. 1970-1975.

ZAFFARONI, Eugenio Raúl; PIERANGELI, José Henrique. Manual de direito penal brasileiro, volume 1: parte geral. 7. ed. rev. e atual. 2. tir. São Paulo: Revista dos Tribunais, 2008, p. 396-398. 
ZANCHETTIA, Alberto; MANCIA, Giuseppe. The dilemma of placebo controlled studies: scientific evidence, guidelines, ethics and regulatory recommendations. Journal of Hypertension 2009, volume 27(1), p. 1-2. 